\title{
Oak Ridge Reservation Bird Records and Population Trends
}

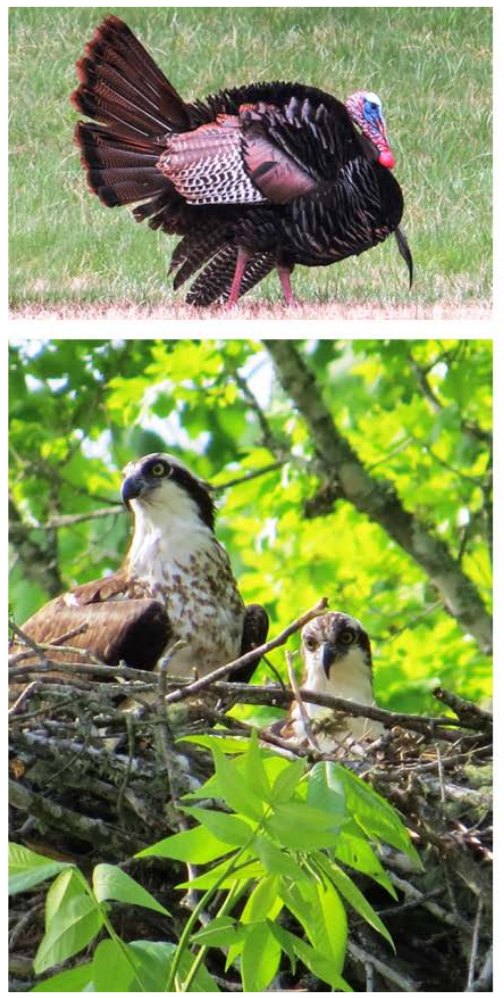

Approved for public release: distribution is unlimited.
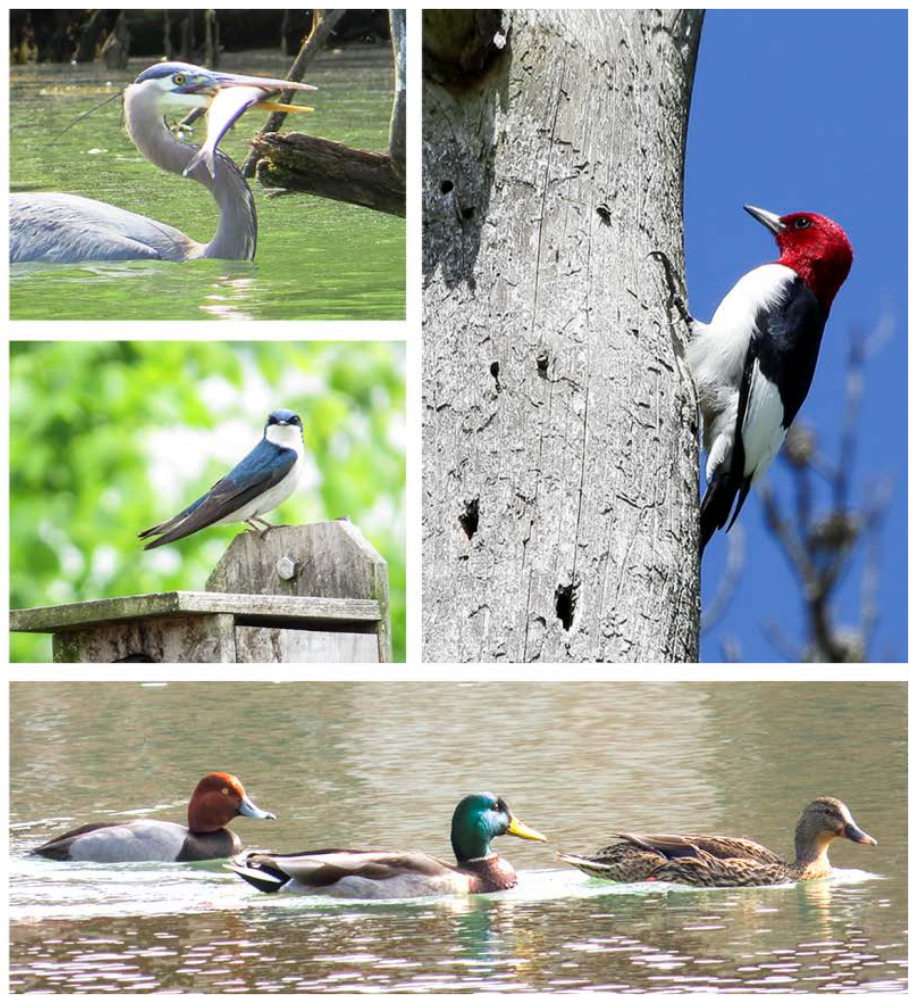

W. K. Roy

N. R. Giffen

M. C. Wade

A. M. Haines

J. W. Evans

R. T. Jett

September 2014 


\section{DOCUMENT AVAILABILITY}

Reports produced after January 1, 1996, are generally available free via US Department of Energy (DOE) SciTech Connect.

Website http://www.osti.gov/scitech/

Reports produced before January 1, 1996, may be purchased by members of the public from the following source:

National Technical Information Service

5285 Port Royal Road

Springfield, VA 22161

Telephone 703-605-6000 (1-800-553-6847)

TDD 703-487-4639

Fax 703-605-6900

E-mail info@ntis.gov

Website http://www.ntis.gov/help/ordermethods.aspx

Reports are available to DOE employees, DOE contractors, Energy Technology Data Exchange representatives, and International Nuclear Information System representatives from the following source:

Office of Scientific and Technical Information

PO Box 62

Oak Ridge, TN 37831

Telephone 865-576-8401

Fax 865-576-5728

E-mail reports@osti.gov

Website http://www.osti.gov/contact.html

This report was prepared as an account of work sponsored by an agency of the United States Government. Neither the United States Government nor any agency thereof, nor any of their employees, makes any warranty, express or implied, or assumes any legal liability or responsibility for the accuracy, completeness, or usefulness of any information, apparatus, product, or process disclosed, or represents that its use would not infringe privately owned rights. Reference herein to any specific commercial product, process, or service by trade name, trademark, manufacturer, or otherwise, does not necessarily constitute or imply its endorsement, recommendation, or favoring by the United States Government or any agency thereof. The views and opinions of authors expressed herein do not necessarily state or reflect those of the United States Government or any agency thereof.

On the cover:

Wild turkey (top left) and male redhead with pair of mallards (bottom right)

(Photos: Kelly Roy); osprey (bottom left), great blue heron (top center), and tree swallow (center) (Photos: Angelina Haines); and red-headed woodpecker (top right) (Photo: Jason Richards). 
Environmental Sciences Division

\title{
OAK RIDGE RESERVATION BIRD RECORDS AND POPULATION TRENDS
}

\author{
W. K. Roy \\ Environmental Sciences Division, Oak Ridge National Laboratory \\ N. R. Giffen \\ Facilities and Operations Directorate, Oak Ridge National Laboratory \\ M. C. Wade \\ CDM Smith \\ A. M. Haines \\ XCEL Engineering, Inc. \\ J. W. Evans \\ Tennessee Wildlife Resources Agency \\ R. T. Jett \\ Environmental Sciences Division, Oak Ridge National Laboratory
}

September 2014

Prepared by

OAK RIDGE NATIONAL LABORATORY

Oak Ridge, Tennessee 37831

managed by

UT-BATTELLE, LLC

for the

U.S. DEPARTMENT OF ENERGY

under contract DE-AC05-00OR22725 



\section{CONTENTS}

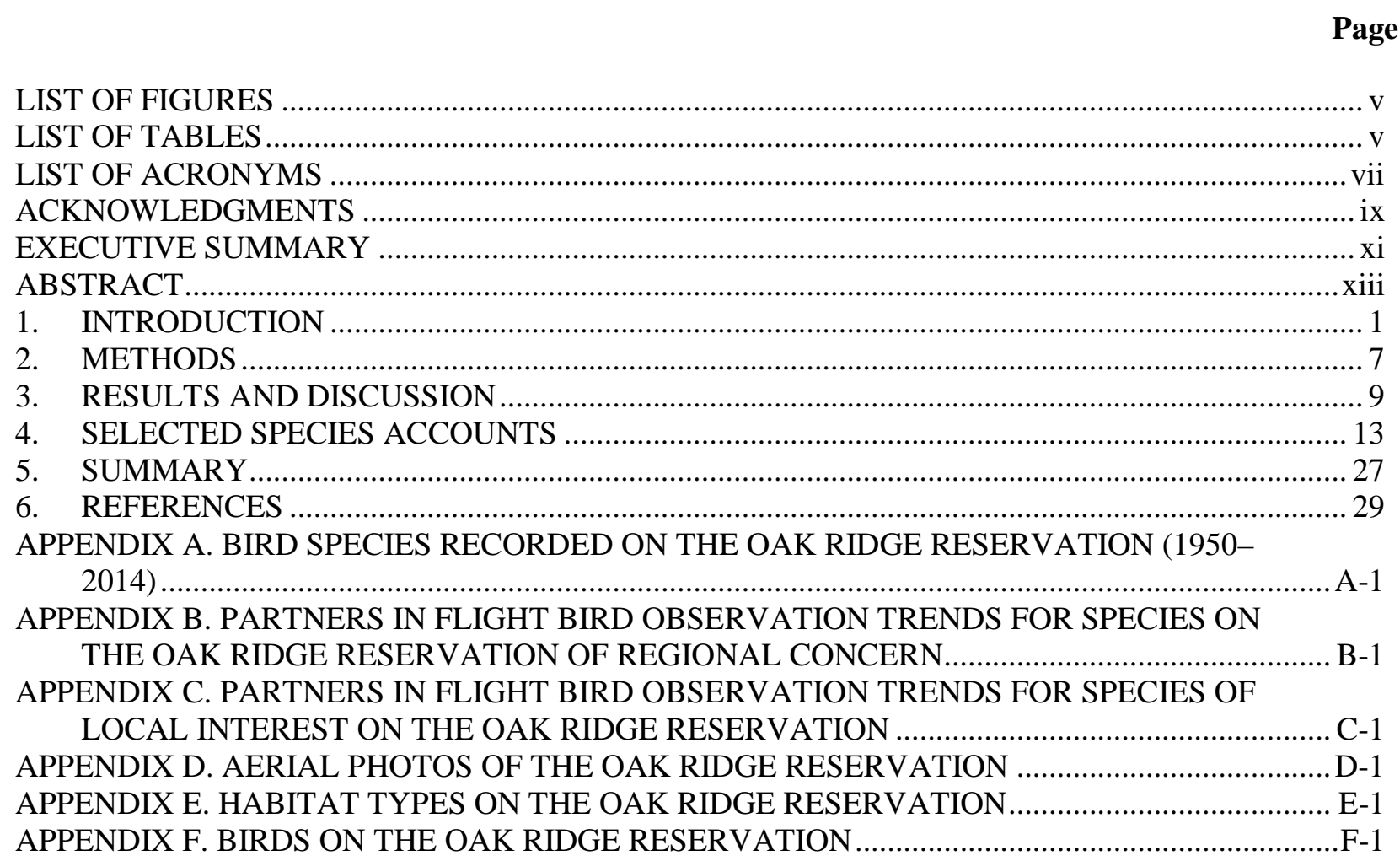





\section{LIST OF FIGURES}

Figures

Fig. 1. The Oak Ridge Reservation (July 2014). ............................................................................. 3

Fig. 2. Oak Ridge Reservation forests by forest groupings .................................................................... 4

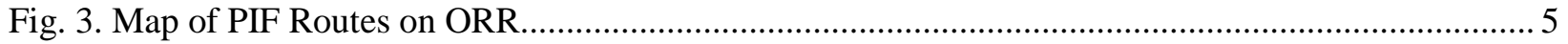

Fig. 4. Bodies of water at East Tennessee Technology Park ............................................................. 14

\section{LIST OF TABLES}

Tables $\quad$ Page

Table 1. Comparison of population trends on the ORR to those in the Appalachian Region for bird species considered by Partners in Flight to be of regional importance ................................... 10

Table 2. Comparison of population trends on the ORR to those in the Appalachian Region for bird

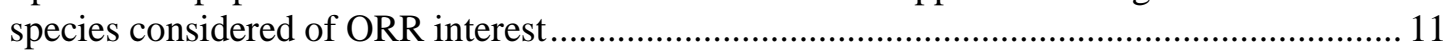





\section{LIST OF ACRONYMS}

$\begin{array}{ll}\text { DOE } & \text { Department of Energy } \\ \text { eBird } & \text { website at: http://eBird.org (See Sullivan et al. 2009) } \\ \text { ETTP } & \text { East Tennessee Technology Park } \\ \text { NWSG } & \text { native warm season grasses } \\ \text { ORNL } & \text { Oak Ridge National Laboratory } \\ \text { ORR } & \text { Oak Ridge Reservation (also referred to as "the Reservation") } \\ \text { PIF } & \text { Partners in Flight } \\ \text { SWSA } & \text { solid waste storage area } \\ \text { Three Bend Area } & \text { Three Bend Scenic and Wildlife Management Refuge Area } \\ & \text { (collectively consists of Solway, Freels, and Gallaher Bends) } \\ \text { TN-Bird } & \text { website at: www.tnbirds.org/birding_tn.htm (see TN-Bird citation) } \\ \text { TVA } & \text { Tennessee Valley Authority } \\ \text { TWRA } & \text { Tennessee Wildlife Resources Agency } \\ \text { UT } & \text { University of Tennessee } \\ \text { Y-12 } & \text { Y-12 National Security Complex }\end{array}$





\section{ACKNOWLEDGMENTS}

The authors gratefully acknowledge those who have played a significant role in support of the study of Oak Ridge Reservation birds over the last 65 years, including Fred J. Alsop; Stanley H. Anderson; Mark Belvin; Than Boves; Steven K. Brinkley; Robert L. Brewer, Jr.; David A. Buehler; Betty Reid Campbell; James M. Campbell; Brian A. Carrico; Jordan Chaney; Doug Colclasure; Bob Collier; Daniel L. Combs; Sherri Cotter; David K. Cox; Janet H. Cushman; Robert M. Cushman; Marcia Davis; K. Dean Edwards; James L. Elmore; Chuck Estes; Lola Estes; Manuel (Dobie) Gillispie; Carole Gobert; Jerry Hadder; Richard S. Halbrook; Carol Hardy; Gary S. Hartman; Brian Henry; Ron Hoff; J. C. Howell; Susan Hoyle; Wesley K. James; J. Devereux Joslin; Roger L. Kroodsma; Louis A. Krumholz; Jim Lane; Edmund LeGrand; Leigh K. Loveday; Robert H. Loveday; Linda K. Mann; Kitty McCracken; Stephany McNew; Jason M. Mitchell; Dollyann Myers; Charles P. Nicholson; Brenda O’Neal; J. B. Owen; David G. Page; Patricia D. Parr; Michael Plaster; Vincent Pontello; R. Scott Reasor; Jason K. Richards; Michael D. Roedel; Martha Rudolph; Steve Rudolph; Michael G. Ryon; Bradley Sample; Elizabeth M. Shilling; Herman H. Shugart, Jr.; Scott Somershoe; Rodney H. Strand; Colin Sumrall; Glenn Suter; Christine Tankersley; Roger Tankersley, Jr.; Shannon A. Young; Beth A. Wade; J. Warren Webb; Christopher Welsh; and others. We also thank Tracy Clem for document preparation, Donna Jo Roy for cover design, and Wendy Hames for editing.

This research was supported by UT-Battelle, LLC, and previous contractors who managed Oak Ridge National Laboratory for the US Department of Energy; Audubon and Cornell Laboratory of Ornithology (eBird); Bird Banding Laboratory_-U.S. Geological Survey; CDM Smith; Tennessee Department of Environment and Conservation; Tennessee Technological University; Tennessee Valley Authority; Tennessee Wildlife Resources Agency; University of Tennessee; US Department of AgricultureWildlife Services; and US Fish and Wildlife Services. 



\section{EXECUTIVE SUMMARY}

This report summarizes the observations of bird species documented on the Oak Ridge Reservation (ORR) from 1950 to 2014. Results and analysis of breeding bird survey data collected for the Partners in Flight program from 1995 to 2013 are a major focus of this document, as are data that were collected during waterfowl surveys conducted from 1990 to 2008. Data were collected with the help of a variety of participants, including members of local, state, and federal agencies, as well as reputable volunteer birdwatchers.

Breeding bird data from the ORR were analyzed and compared with large-scale population trends found in the Appalachian Region. Results of this study indicate that population trends on the ORR do not necessarily mirror trends found throughout the Appalachians. In nearly all instances where discrepancies exist, however, bird populations on the ORR are doing better than in the Appalachian Region.

Brief summary accounts are provided for selected species of interest and for all state-listed species known to have occurred on the ORR. Some very interesting bird species have appeared on the ORR in the last 65 years. We identified 228 species of birds that occurred on the ORR during this period. Of these, 120 species are believed to be breeding birds on the ORR.

We have done our best to provide documentation of rare species in this report, as ornithologists may debate some of these records for years to come. The attention given in this report to those species that may have occurred only once or twice in recent decades reflects our interest in documenting these occurrences, rather than an emphasis on managing for birds that may have a low probability of recurrence.

In addition to rare species, the reader is also likely to take interest in the lack of some species that should occur on the ORR, but for which we have no known records. Factors that likely contributed to the paucity of some records include limited access (for observers) to the ORR, restrictions on photographic equipment during most of the period, lack of funding for bird-related research, and relevance of avian research to the US Department of Energy mission. It is hoped that the work documented in this report will serve future researchers of Oak Ridge Reservation avifauna, and that those researchers will continue to add to the bird species list and the information contained herein. 



\begin{abstract}
Bird data have been collected through surveys, environmental assessments, and other observations for decades in the Oak Ridge National Environmental Research Park, located on the US Department of Energy's Oak Ridge Reservation (ORR) in East Tennessee. Birds were recorded in a variety of habitats, including wetlands, interior forests, grasslands, ponds, corridors, forest edges, and more. Most of the information was gathered from waterfowl surveys conducted from 1990 to 2008, from Partners in Flight (PIF) breeding bird surveys conducted from 1995 to 2013, and from past publications and research on Reservation birds. We have also included our own observations and, in a few instances, credible observations of ORR birds of which we have been made aware through eBird or discussions with area ornithologists and bird watchers. For the period 1950-2014, we were able to document 228 species of birds on the ORR. Several of these species are known from historic records only, while others were not known to have ever occurred on the Reservation until recently. This report does not include PIF breeding bird data from the 2014 season or any records after July 2014. Twenty-two species—approximately 10\% of the total number of species observed-have state-listed status in Tennessee as endangered, threatened, or in need of management. Of the 228 species we documented, 120 are believed to be breeding birds on the ORR.
\end{abstract}





\section{INTRODUCTION}

The Oak Ridge Reservation (ORR; also “the Reservation”) is a 33,481 acre (13,549 ha) US Department of Energy (DOE)-owned property located in Roane and Anderson counties in East Tennessee (Fig. 1). According to Parr et al. (2014), "The ORR is recognized as the largest contiguous protected land ownership in the southern Valley and Ridge Physiographic Province, making it a significant regional resource.” It includes Oak Ridge National Laboratory (ORNL), the Y-12 National Security Complex (Y-12), and East Tennessee Technology Park (ETTP). The majority of the ORR remains largely undeveloped, though areas around the three complexes are typical of government-owned industrial/research facilities that include high security areas. Most of the property was acquired by the federal government in the 1940s to act as a security buffer for top-secret military activities. Since that time, certain property such as Haw Ridge Park, Horizon Center, Rarity Ridge, various holdings at ETTP, and other acreage have changed ownership or lessee arrangements. For purposes of this report, however, bird records are included from formerly-owned ORR DOE property and from the boundary waters of the Reservation.

There were approximately 1,000 individual farmsteads on the ORR prior to government acquisition of the land. These farmsteads consisted of forest, woodlot, open grazed woodland, and field habitats. The ORR is much more heavily forested today than it was before the government's acquisition of the property. The various maps and photos presented in this report and in Appendixes D and E will help acquaint the reader with current conditions that may be encountered on the Reservation.

Remote-sensing analyses show that in 1994, approximately 70\% of the ORR was in forest cover and about $20 \%$ was transitional, consisting of old fields, agricultural areas, cutover forestlands, roadsides, and utility corridors (Washington-Allen et al. 1995). Natural areas of the ORR are mainly in contiguous native eastern deciduous forest, and forested areas (i.e., hardwood and pine, with many areas in blocks greater than 99 acres [40 ha]) are found throughout the Reservation. Outbreaks (1993-94 and 1999-2001) of southern pine beetle (Dendroctonus frontalis) impacted more than half of the approximately 9,489 acres (3,840 ha) of planted and natural pine stands (Parr et al. 2012), which have since naturally regenerated (with only a few re-plantings) as pine and pine-hardwood stands. ORR forests are mostly oak-hickory, pine-hardwood, or pine. Minor areas of other hardwood forest cover types are found throughout the Reservation, including northern hardwoods, a few small natural stands of hemlock or white pine, and floodplain forests (Parr and Hughes 2006) (Fig. 2). Less than 2\% of the ORR is believed to be in agricultural fields (Mann et al. 1997), many of which have now been planted in native warm season grasses. Approximately 13\% of the ORR is estimated to be in living pine or mixed pine forests (Parr et al. 2012). Figure 2 displays the ORR forests by forest groupings based on forestry compartment maps generated in the 1980s.

One of the earliest published species lists for birds of the ORR comes from a study conducted in and around White Oak Lake and White Oak Creek (Krumholz 1954). This was followed by a grid point survey conducted in the White Oak Creek and Melton Branch Watersheds (Howell 1958). Other quantitative bird surveys were conducted on the ORR through the mid-1990s, including surveys at the Breeder Reactor Site, a large peninsula on the southwestern corner of the Reservation (PMC 1977). The Tennessee Valley Authority (TVA) now owns this site (Fig. 1). Additional breeding bird surveys have been conducted in the Walker Branch Watershed, a 247 acre (100 ha) area of mainly mature hardwoods located on the south side of Chestnut Ridge (Anderson and Shugart 1974, Smith and Shugart 1987). Important research associated with breeding bird populations on power line rights-of-way and adjacent forest has also been conducted on the ORR (Anderson et al. 1977, Kroodsma 1982, Kroodsma 1984a, Kroodsma 1984b). Additional avian work was conducted in white pine (Pinus strobus) and loblolly pine (Pinus taeda) plantations adjacent to hardwood forest (Hardy 1991). Bird data also were collected 
between 1986 and 1991 as part of the Tennessee Breeding Bird Atlas project (Nicholson 1997). A major reservation-wide survey of protected terrestrial vertebrates, including extensive bird surveys, was conducted from 1994 to 1996 by Mitchell et al. (1996). 


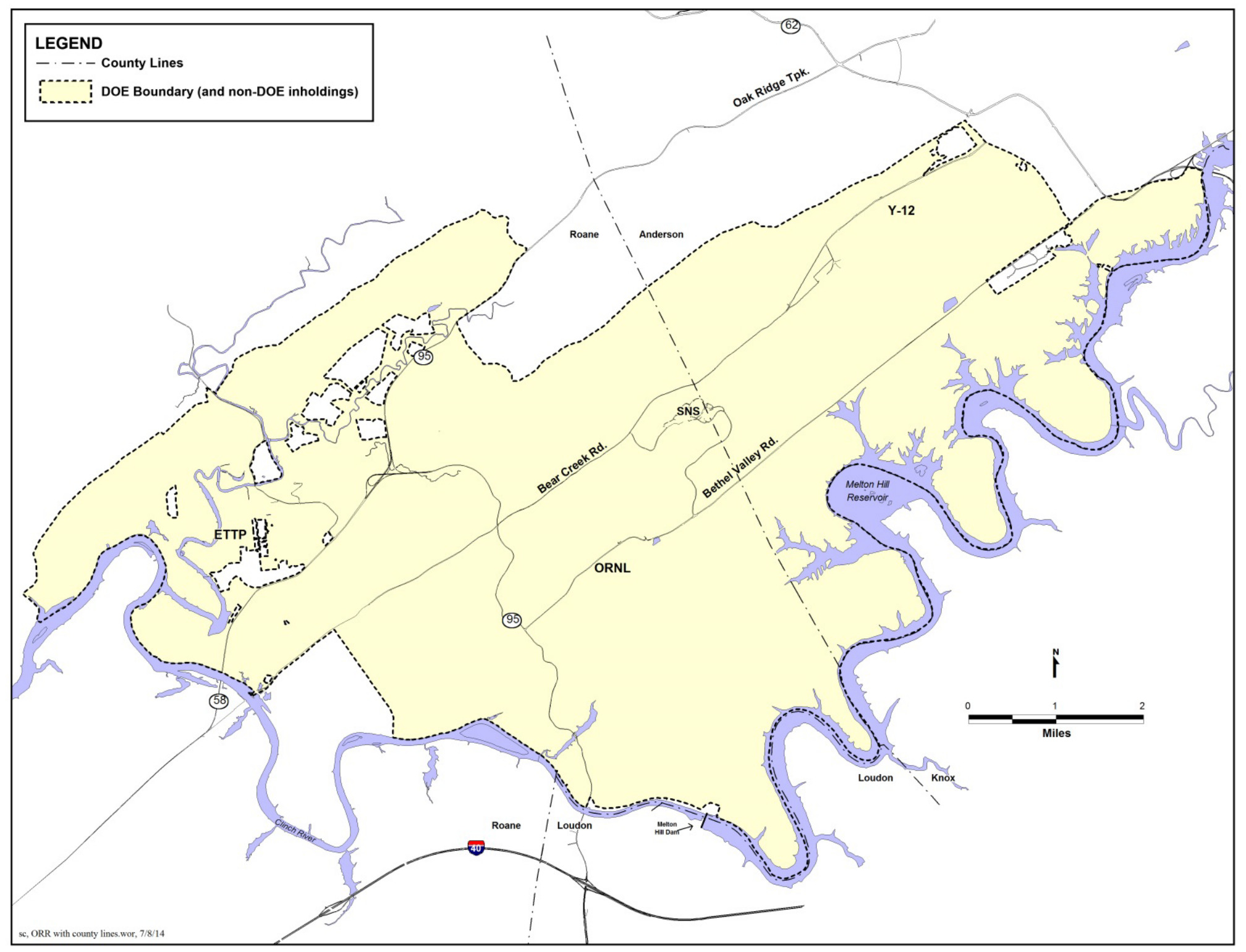

Fig. 1. The Oak Ridge Reservation (July 2014). 


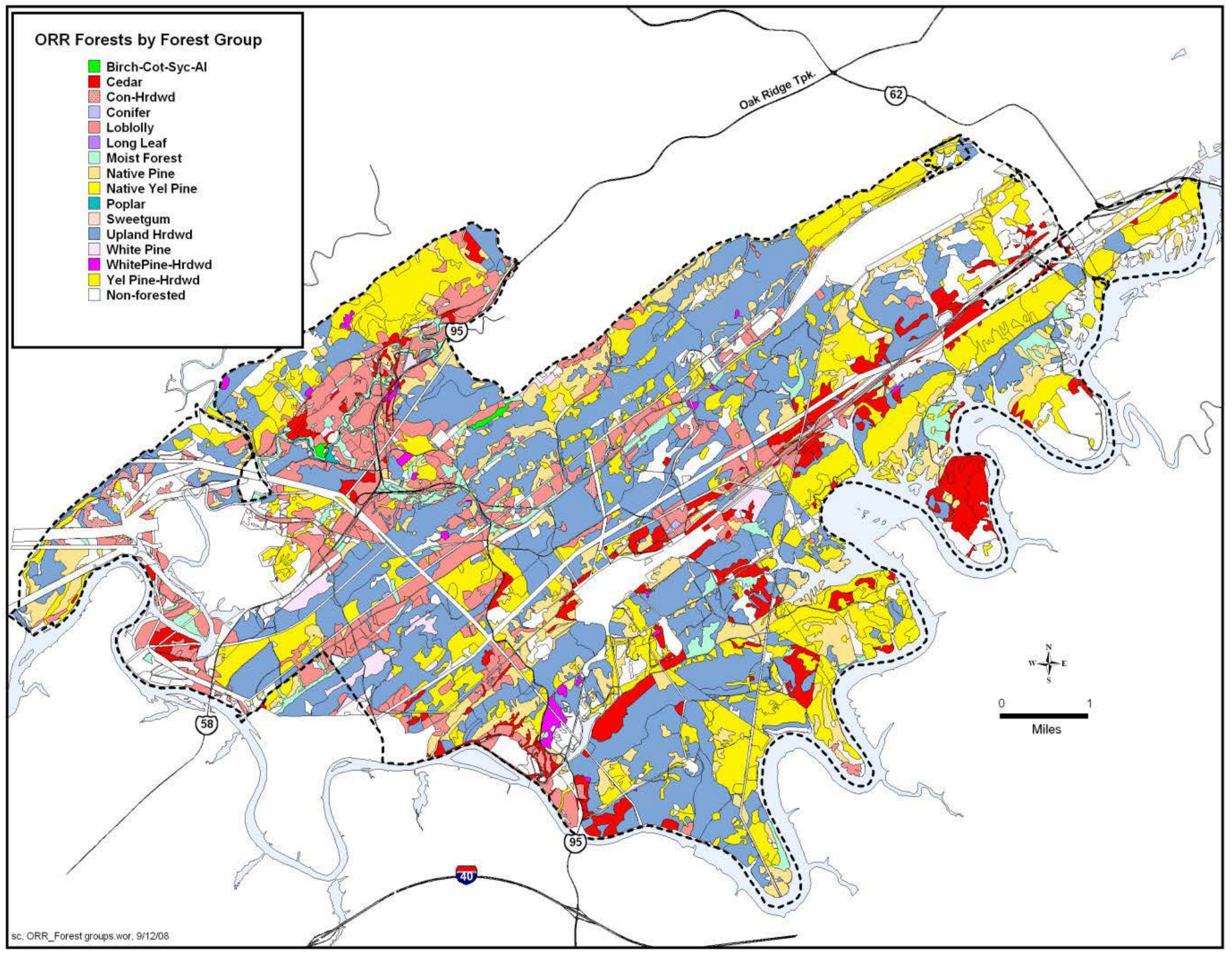

Fig. 2. Oak Ridge Reservation forests by forest groupings (Giffen et al. 2012). 
Bird watching and bird research on the ORR has been limited, primarily because most of the Reservation is not open to the public. One of the last publications of bird population data specifically pertaining to the ORR was done by Mann et al. (1997). Mann and coauthors documented the many historic bird surveys that had been conducted on the ORR and summarized the first two years (1995-96) of Partners in Flight (PIF) breeding bird data collected on the Reservation. These data were collected from the points displayed in the map of ORR PIF routes in Fig. 3.

In 1995, yearly breeding bird surveys were initiated on the ORR through the Tennessee Wildlife Resources Agency (TWRA) as part of the PIF program. These annual surveys have been conducted on a regular basis since that time. The PIF program, formed in 1990, was created in response to declining populations in land bird species (PIF 2013). PIF coordinates groups throughout the Western hemisphere to conduct annual bird surveys and to provide data for an international database. The collected data can then be used to determine population trends, species health, and changes in habitat, thereby helping to inform agencies and policy makers of the latest changes in bird populations. This document summarizes the PIF breeding bird data collected on the ORR and trends in populations for many avian species since 1995, as well as all known bird records for the ORR since 1950.

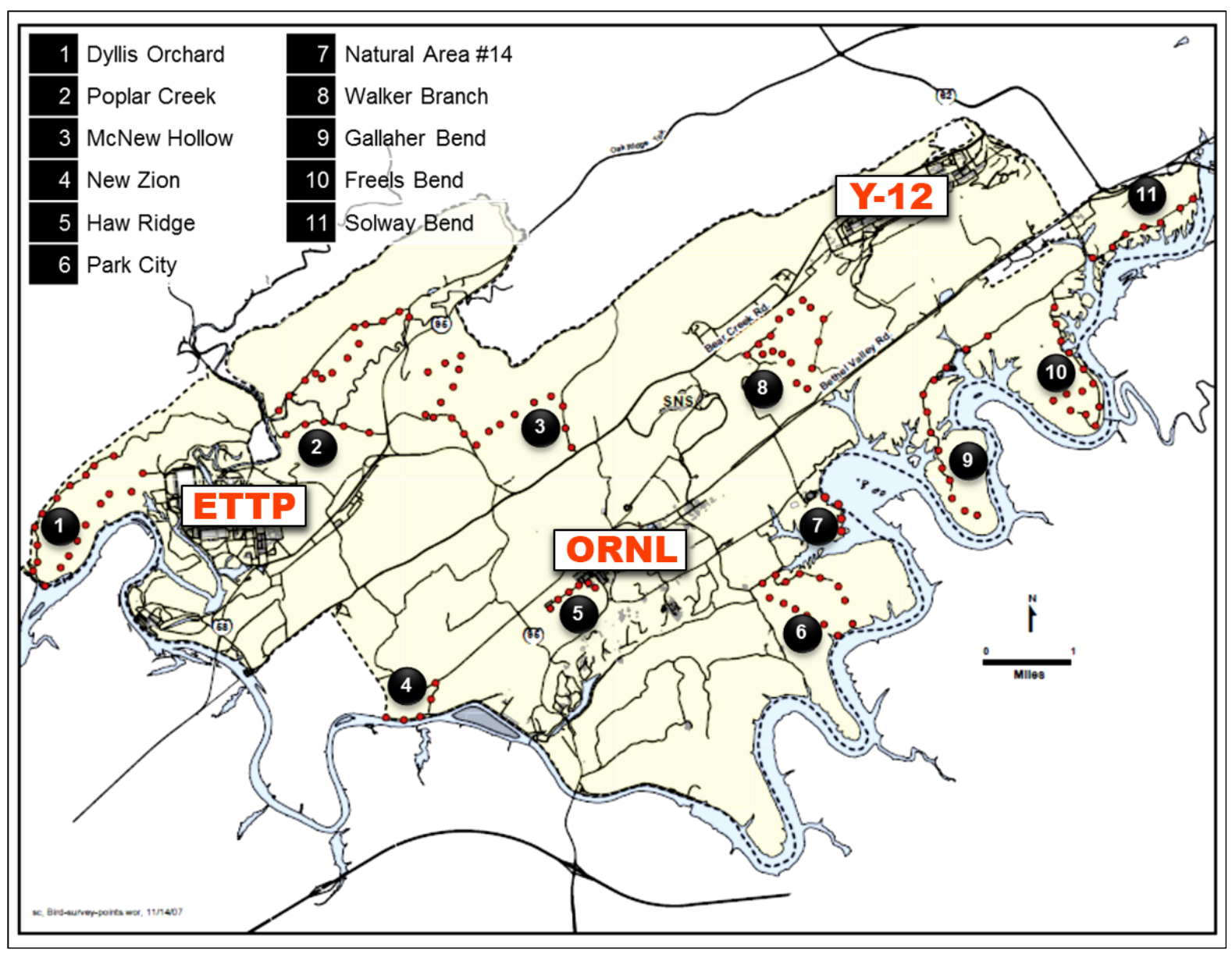

Fig. 3. Map of PIF Routes on ORR. 



\section{METHODS}

The data presented herein were gathered from the following sources: (1) historical studies, (2) yearly PIF breeding bird surveys, (3) bird data obtained from numerous environmental assessments conducted at various sites on the ORR, (4) incidental bird sightings, and (5) records obtained from eBird (Sullivan et. al. 2009). Much of the data presented were acquired from 11 established PIF survey routes on the ORR (Fig. 3).

These PIF survey routes cover the majority of habitat types found on the ORR, including hardwood forest, field-forest edge, old field, grasslands, riparian zones, and wetlands. Many of these habitat types are depicted in Appendixes D and E. The 11 routes encompass 161 observation points spaced a minimum of $300 \mathrm{ft}$ (91 m) apart. Points are surveyed for established time intervals in which all birds seen or heard are recorded. From 1995 through 2003, the survey time was limited to $5 \mathrm{~min}$ at each point. The time spent at each point was increased to 10 min starting in 2004 to give additional assurance that all birds present in the area would be recorded. Data were further segregated into sub-intervals within the overall time period. This enables all PIF researchers to be able to ascertain the numbers of additional species detected with the increased time interval and further serves to increase validity of spatial comparisons. Approximate distance from survey point to bird was also recorded for each observation. Data from environmental assessment work and from incidental bird sightings were significant in supplementing the PIF data. These other sources of data proved to be particularly critical with regard to ORR bird records in that a number of rare species were recorded outside the breeding season.

A number of bird species found on the ORR are deemed to be of "regional concern" by the Partners in Flight organization. PIF determines regional importance by scoring a species in a combination of various assessment factors that include six global factors, a regional assessment, and two area importance factors (Panjabi et al. 2012). Global factor scores are given for population size, breeding distribution, nonbreeding distribution, threats to breeding, threats to non-breeding, and population trend. Regional assessment scores basically apply global factor criteria on a regional level. The two area importance factors are relative density (the mean density of a species within the given bird conservation region), and percent of population (the proportion of the global population of a species within the given bird conservation region). Species that score high (i.e., are of increased vulnerability) in these categories are labeled regionally important.

Population trends for a number of ORR breeding bird species were determined by graphing data using three different criteria: (1) the normalized number of observations of a particular species per year, (2) the percent of observations of that species out of the total number of observations, and (3) the percent of all points along all routes in which that species was observed (Appendixes B and C). In the first instance, data were normalized because the number of points surveyed each year varied. The greatest number of points surveyed in a single year was 161 (in 1997) and the fewest number ever surveyed was 46 (in 2004). The data were normalized to account for these discrepancies and were treated as if 161 points were surveyed every year. The problem with this approach, however, is that it assumes all species have equal odds of detection at all points, which is not true. Therefore, the other two criteria also were used in examining the data, although these, too, have shortcomings. For these reasons, a weighted approach was used to determine whether a species' population was considered to be stable, increasing, or decreasing.

Each graph in Appendixes B and C contains the equation of the linear trend line in slope intercept form, $\mathrm{y}=m \mathrm{x}+\mathrm{b}$, where $m=$ slope. If agreement existed in all three graphs for a given species with respect to positive or negative slope, and if at least two of the three graphs showed a slope $>0.05$ or $<-0.05$, then the species' population was determined (by weight of evidence) to be increasing or decreasing, respectively, since 1995. 
Regional data for general population trends were taken from the PIF Species Assessment Database, which was updated in 2012 (PIF 2012). The bird species database for the ORR was last updated in 2013, but general population trends that have been observed since the 1990s should not be significantly altered by the absence or presence of one year of data (i.e., 2013 data). 


\section{RESULTS AND DISCUSSION}

A total of 228 bird species has been recorded on the ORR since 1950, all of which are listed in Appendix A; images of some of the species are shown on the cover of this report and in Appendix F. Of these 228 species, 113 have been recorded during the PIF breeding bird surveys. Appendix A also provides the number of observations, by species, recorded during PIF surveys from 1995 to 2013. Nine species of birds never recorded on PIF surveys are (or were) known to occur year-round on the ORR and are either known or presumed breeding birds on the ORR. Most of these species have remained undetected on breeding bird surveys because they occur only in very low numbers on the ORR, the breeding bird survey routes do not bisect their known habitats, or they are not particularly vocal—making them difficult to detect by ear. These species are mute swan (Cygnus olor), ruffed grouse (Bonasa umbellus), pied-billed grebe (Podilymbus podiceps), bald eagle (Haliaeetus leucocephalus), American coot (Fulica americana), American woodcock (Scolopax minor), rock pigeon (Columba livia), barn owl (Tyto alba), and loggerhead shrike (Lanius ludovicanius).

Three species identified in Appendix A as primarily "winter" species on the ORR were observed on PIF breeding bird surveys. These are the ring-billed gull (Larus delawarensis; one record), yellow-bellied sapsucker (Sphyrapicus varius; two records), and yellow-rumped warbler (Setophaga coronata; one record). These birds could have "over-summered" on the ORR (possibly because of injury) or could have been late in migrating, but they are not considered ORR breeding birds, although Hardy (1991) also reported sapsuckers during the breeding season. Summer records of yellow-bellied sapsuckers in Tennessee, especially those below about 3,500 ft (1,067 m) elevation, are of particular interest to ornithologists, and the authors are mindful of summer records for this species on the Reservation.

Five species identified in Appendix A as “migrants” were observed on PIF breeding bird surveys. These are the blue-headed vireo (Vireo solitarius), Swainson's thrush (Catharus ustulatus), northern waterthrush (Parkesia motacilla), bay-breasted warbler (Setophaga castanea), and rose-breasted grosbeak (Pheucticus ludovicianus). As with the three "winter" species observed on PIF surveys, these species (with the exception of the vireo) are not considered ORR breeding birds despite having been recorded on breeding bird surveys. The highest number of cumulative records for any of these species in 19 years of conducting ORR breeding bird surveys is for the blue-headed vireo $(n=4)$. Of the eight species found on PIF surveys that do not have either "summer" or "year-round" status, the blue-headed vireo is the most likely candidate to actually be breeding on the ORR, and it is listed in Appendix A as a potential breeding bird on the ORR.

There are 28 bird species found on the ORR that are considered to be of concern to PIF because of their declining populations in the Appalachian region. The extensive amount of bird data gathered during 19 years of ORR PIF surveys allowed for population trend analyses of 23 of these regionally important species. Five other species of regional concern were not included in these analyses because they were rarely recorded during PIF surveys, and this reduced frequency of occurrence did not allow for the graphing of meaningful trends. Population trends for these 23 species were compared to trends found in the PIF Appalachian Bird Conservation Region (Table 1). For 16 of these species ( 70\%), the ORR trends differed from those documented by PIF for the Appalachian region (Table 1). Interestingly, these 16 species showed either increasing $(n=10)$ or stable $(n=6)$ population trends on the ORR, in contrast to decreasing trends noted for the Appalachian region as a whole (Table 1, Appendix A).

The differences noted between ORR and Appalachian Region PIF data are not surprising, because regional evaluations typically encompass a wider range of habitats, human activity, and ecological pressures than what is experienced within a subset of the region. Additionally, destruction or deterioration of habitat, and anthropogenic perturbations in general, are often much reduced or occur more slowly on "protected" federal lands. 
Table 1. Comparison of population trends on the ORR to those in the Appalachian Region for bird species considered by Partners in Flight to be of regional importance

\begin{tabular}{|c|c|c|}
\hline Bird Species & Oak Ridge Reservation & Appalachian Region \\
\hline northern bobwhite & $\mathrm{D}$ & $\mathrm{D}$ \\
\hline chuck-will's-widow & $\mathrm{D}$ & $\mathrm{D}$ \\
\hline eastern whip-poor-will & $S$ & $\mathrm{D}$ \\
\hline chimney swift & I & $\mathrm{D}$ \\
\hline belted kingfisher & S & $\mathrm{D}$ \\
\hline northern flicker & $\mathrm{D}$ & $\mathrm{D}$ \\
\hline eastern wood-pewee & I & $\mathrm{D}$ \\
\hline Acadian flycatcher & I & $\mathrm{D}$ \\
\hline yellow-throated vireo & $\mathrm{D}$ & $\mathrm{D}$ \\
\hline barn swallow & $S$ & $\mathrm{D}$ \\
\hline wood thrush & $\mathrm{D}$ & $\mathrm{D}$ \\
\hline brown thrasher & I & $\mathrm{D}$ \\
\hline worm-eating warbler & $\mathrm{S}$ & $\mathrm{D}$ \\
\hline Louisiana waterthrush & I & $\mathrm{D}$ \\
\hline blue-winged warbler & I & $\mathrm{D}$ \\
\hline Kentucky warbler & I & $\mathrm{D}$ \\
\hline cerulean warbler & S & $\mathrm{D}$ \\
\hline prairie warbler & $\mathrm{D}$ & $\mathrm{D}$ \\
\hline yellow-breasted chat & $S$ & $\mathrm{D}$ \\
\hline eastern towhee & I & $\mathrm{D}$ \\
\hline field sparrow & I & $\mathrm{D}$ \\
\hline summer tanager & $\mathrm{I}$ & $\mathrm{D}$ \\
\hline eastern meadowlark & $\mathrm{D}$ & $\mathrm{D}$ \\
\hline
\end{tabular}

Notes: $\mathrm{D}=$ decreasing trend, $\mathrm{I}$ = increasing trend, $\mathrm{S}=$ stable trend.

Population trends for nine additional species not considered to be of regional concern (by PIF criteria) also were evaluated. The aim of this analysis was to evaluate a diverse group of species outside of the PIF regional concern list that would provide additional data of value to ORR wildlife managers in determining the direction of management of bird populations on the Reservation in the future. Evaluated species included neotropical migrants (blue-gray gnatcatcher [Polioptila caerulea], northern parula [Setophaga americana], prothonotary warbler [Protonotaria citrea], blue grosbeak [Passerina caerulea], orchard oriole [Icterus spurius], willow flycatcher [Empidonax traillii]) and permanent residents (pileated woodpecker [Dryocopus pileatus], hairy woodpecker [Picoides villosus], brown-headed cowbird [Molothrus ater]). They include both species of forests or wooded areas (blue-gray gnatcatcher, northern parula, prothonotary warbler, pileated woodpecker, hairy woodpecker), species found in more open habitats (blue grosbeak, orchard oriole, willow flycatcher), and one nest parasite (brown-headed cowbird). 
ORR population trends for these species were evaluated and are displayed in Table 2. Of these nine species, PIF trending data show four with increasing, two with stable, and three with decreasing populations in the Appalachian region. On the ORR itself, however, breeding bird data indicate that six have increasing populations and three have stable populations (Table 2, Appendixes B and C). Of the three species determined by PIF to be in decline, two (blue-gray gnatcatcher and brown-headed cowbird) have increasing populations, and one (blue grosbeak) has a stable population on the ORR.

Table 2. Comparison of population trends on the ORR to those in the Appalachian Region for bird species considered of ORR interest

\begin{tabular}{c|c|c}
\hline Bird Species & Oak Ridge Reservation & Appalachian Region \\
\hline hairy woodpecker & I & I \\
\hline pileated woodpecker & I & I \\
\hline willow flycatcher & S & D \\
\hline blue-gray gnatcatcher & I & S \\
\hline prothonotary warbler & S & I \\
\hline northern parula & I & D \\
\hline blue grosbeak & S & D \\
\hline brown-headed cowbird & I & S \\
\hline orchard oriole & I & \\
\hline
\end{tabular}

Notes: $\mathrm{D}$ = decreasing trend, $\mathrm{I}$ = increasing trend, $\mathrm{S}=$ stable trend.

The data seem to indicate that interior forest and forest edge habitats on the ORR remain largely intact, while grassland and early successional habitats may be lacking. Nevertheless, ORR population trend data alone have not proven to be good predictors of habitat type changes on the ORR, because both increasing and decreasing trends are noted for bird species occupying similar niches (Appendixes B and C).

PIF data are invaluable for examining bird population trends. However, PIF has been in existence only long enough to offer what some might consider "long-term" trends. Caution should be used in interpolating PIF population trends, and all data must be fully evaluated before making conservation decisions. This is especially true for neotropical migrant species that also are affected by conditions away from their ORR breeding grounds.

It is interesting to note that ORR bird species with declining population trends did not share a specific nesting strategy. Nesting "types” for birds on the ORR included buildings and structures, burrows, cliffs, cavities, shrubs, trees, ground, and nest parasites. Of the seven species noted to be in decline on the ORR (Table 1), two are ground nesters (northern bobwhite and eastern meadowlark) and one (prairie warbler) is known to nest close to the ground at times. Increasing populations of raccoons (Procyon lotor), coyotes (Canis latrans), or other nest predators on the Reservation could play a role in the apparent decrease of these bird species locally. These declines could also be related to other factors such as habitat loss, severe weather events, disease, etc.

The data yielded by these surveys offer interesting opportunities for further population analysis. It should be kept in mind, however, that the data gathered each year only offer a "snapshot" of bird populations on the ORR. Other variables and sources of error may be present in this set of data, such as adverse weather conditions that cause birds to be less active, inconsistent use of certain routes and points, and surveyor 
bias. It is also believed that certain early-arriving migrants, such as black-throated green and black-andwhite warblers, are probably underrepresented on PIF surveys because they are generally much more vocal a month or so before the surveys are conducted. Additionally, swallow species, as well as some flycatchers, tend to be less active in the early morning hours when most PIF surveys are conducted. Although PIF protocols limit variability in time of day and time of year when surveys are conducted, these variables can definitely affect the data. Nevertheless, species richness often is considered the ultimate measure of diverse, quality habitat. With 228 species of birds recorded on the Reservation, the ORR stands out by any measure as an important bird area. 


\section{SELECTED SPECIES ACCOUNTS}

The following are select accounts of 72 bird species; their presence is an indicator of the rich habitat diversity on the ORR. They are presented in phylogenetic order according to the American Ornithologists Union (AOU 1998; AOU 2013). Maps or pictures of some of the major areas mentioned in these descriptions can be found in Figs. 1-3 in Section 1 and Fig. 4, below. These accounts include rare species occurrences and/or species that are indicative of unique ORR habitats (e.g., large areas of interior forest, grasslands, wetlands, ponds, etc.) that may not be found in surrounding developed areas. Included in these accounts are all Reservation species that the Tennessee Fish and Wildlife Commission has proclaimed are "In Need of Management," "Threatened," or "Endangered” as of August 2000. While these accounts are far from all-inclusive, the goal is to aid the readers' understanding of ORR avifauna. Admittedly, the authors can include only data for which they are aware; there can be little doubt that others have recorded observations, and perhaps even species, which are not accounted for in this document. 


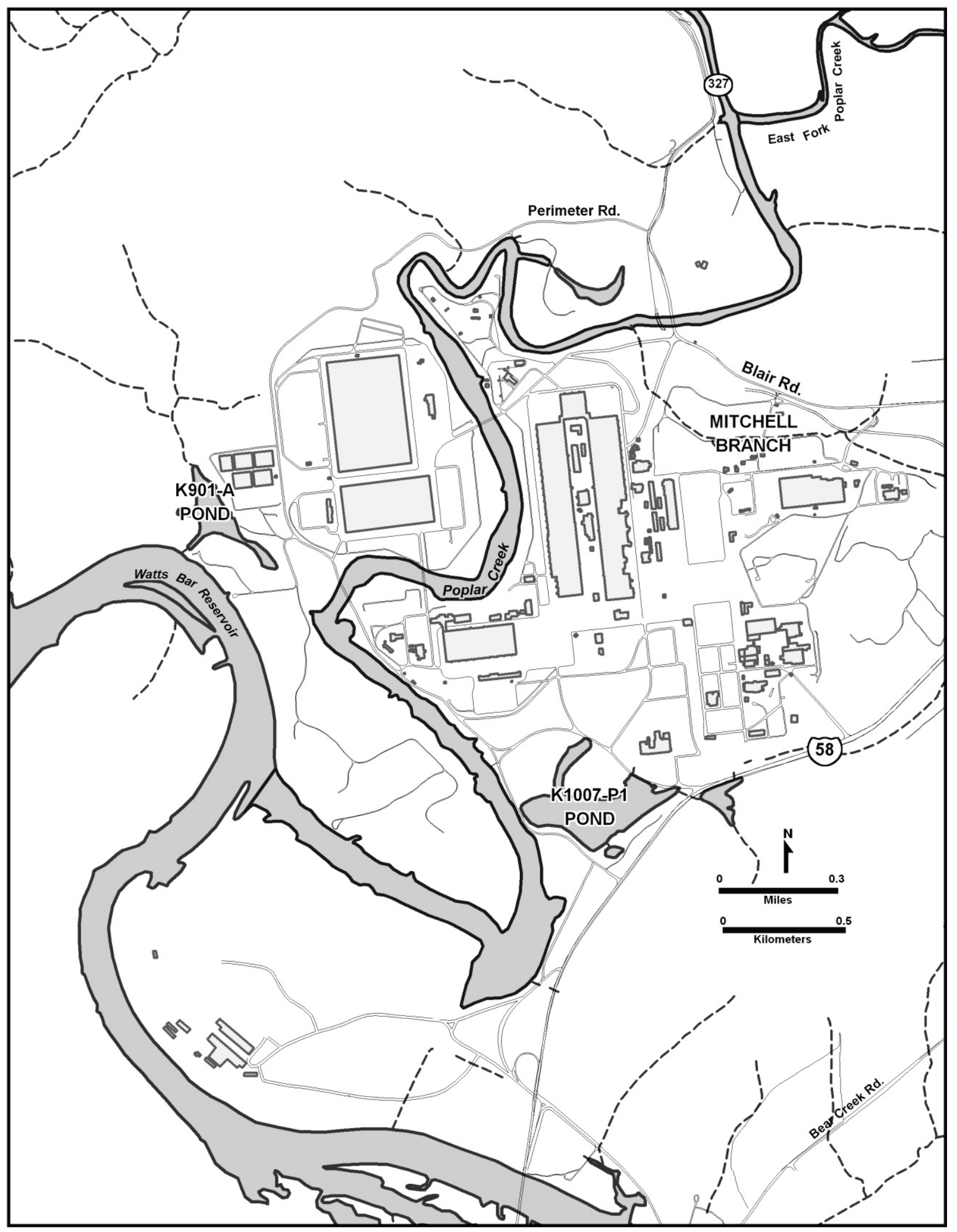

Fig. 4. Bodies of water at East Tennessee Technology Park (Hughes and Thompson 2013). 
Ross's Goose (Chen rossii-occasional): Ross's goose is a regular migrant and wintering bird in Tennessee, though fairly uncommon away from the Mississippi River Valley. They are often seen migrating, flying, and/or foraging with snow geese (TWRA 2012). Individual Ross's geese have been observed twice on the Reservation, in the months of January and February. The most recent record is from just northeast of the ORNL Swan Pond in January 2012, among a flock of Canada geese.

Canada Goose (Branta canadensis_-year-round): Krumholz (1954) reported six Canada geese using White Oak Lake as a nighttime resting spot for several weeks between October 1952 and May 1953. It is not known if the geese Krumholz observed were of the giant "maxima" race, the race re-introduced in East Tennessee on the Melton Hill Reservoir in 1972 (Nicholson 1972) after being extirpated from the state near the turn of the 20th century (Hanson 1965). Canada geese rapidly expanded throughout the state in the 1970s and 1980s, leading many agencies to implement nuisance control measures in the 1990s. Approximately 1,450 birds were relocated off the ORR, including 506 from 1995 to 1999 (Roy et al. 2004) and another 950 from 2004 to 2013. A federal permit was obtained to addle goose eggs on the ORR, and 454 eggs were addled from 2005 to 2014. Additional goose control measures on the ORR included harassment and habitat manipulations to discourage geese. These efforts resulted in a reduction in the Canada goose population on the ORR from 1,500 birds in 1990 to 1,400 birds in 2004 (Roy et al. 2004), to <100 birds by 2013. Although 95\% of ORR Canada geese are non-migratory residents, Roy et al. (2004) documented movements of 28 "Reservation" geese to other states and Canada, including one adult female that traveled 1,206 miles (1,940 km) (straight line distance) to Nunavut, Canada, and returned to the ORR.

Mute Swan (Cygnus olor-year-round): There are no known records of wild mute swans on the ORR. "Domesticated," pinioned mute swans, however, were present on the ORNL Swan Pond from 1964 to 2004 and produced a number of cygnets. The last four mute swans on the pond were rounded up and donated to a private Scott County landowner in 2004.

White-winged Scoter (Melanitta fusca-occasional): This scoter turned up at numerous locations throughout East Tennessee in late winter 2013-14. Three birds were reported on Melton Hill Embayment by Beth Schilling on February 10, 2014, and by Stephany McNew and Colin Sumerall on February 15, 2014 (eBird). Ron Hoff and Dollyann Myers reported one female white-winged scoter near Solway Bridge on March 13, 2014 (TN-Bird).

Common Goldeneye (Bucephala clangula - winter): Two individuals were reported at approximately Clinch River mile 44.4, mid-channel near the Knox/Anderson county line, along the southwest side of Haw Ridge Park, by Kelly Roy on January 2, 2010, on a Knoxville Christmas Count. A female common goldeneye was reported by Michael Plaster (eBird) at the Swan Pond at ORNL on April 5, 2013.

Northern Bobwhite (Colinus virginianus - year-round): Krumholz (1954) recorded this species in the area of White Oak Lake. Howell (1958) reported it for the Melton Valley Area but noted that it was disappearing from that area. Northern bobwhites were recorded on the ORR along transmission line corridors during a study conducted in 1974 and were found to be more prevalent along narrower (13 yd [12 m] wide), as opposed to wider (33.4 yd [30.5 m] wider), corridors (Anderson et al. 1977). Kroodsma (1984a, 1984b) recorded northern bobwhite along power-line edges on the ORR in the mid to late 1970s. The most common areas noted for this species during PIF surveys have been at Dyllis Orchard/Raby Road (1996-2003, 2005, 2007-08), Freels Bend (1996-2001, 2003, 2006, 2011, 2012) and Poplar Creek (1996-2000, 2002-03, 2008). A recent grassland bird survey noted no northern bobwhites in exotic grass fields and only low numbers in early successional and mid-successional cover types (Brinkley and Buehler 2012). This species has shown a general decline in observations since 1995 (Appendix B). Efforts are ongoing on the Reservation to maintain early successional habitat for this species, including prescribed burns, establishment of native grasses, and thinning of pine stands. 
Ruffed Grouse (Bonasa umbellus - year-round): This species is quite rare on the ORR and has never been recorded on a PIF survey, even though it can be found in good numbers, in some years, 6 miles $(10 \mathrm{~km})$ northwest of the Reservation (south of Big Brushy Mountain). Krumholz (1954) recorded this species in the area of White Oak Lake, and there have been a number of anecdotal records for this species on the ORR. It has been observed on Pine Ridge near Gum Branch Road (single specimen). Another grouse was flushed two consecutive mornings in November 2005 on Haw Ridge, 0.6 mile (1 km) south of Kerr Hollow Quarry. More recent confirmations of this species have come from two fatal window strikes at ORNL buildings, one in November 2008 at the Spallation Neutron Source, and one in August 2010 at Building 4500N.

Horned Grebe (Podiceps auritus - winter): This species has been recorded at least eight times on the ORR since 1994. It occurs during the winter season and has been found on the ORR in the months of November, January, February, and March. The most recent observations came from the K1007-P1 Pond at ETTP (Fig. 4) in late March 2012 and from near Solway Bridge, as reported by Ron Hoff and Dollyann Myers, on March 13, 2014 (TN-Bird).

Red-necked Grebe (Podiceps grisegena-occasional): Two red-necked grebes were well-documented on Melton Hill Lake just above Melton Hill Dam from March 10 to March 28, 2014. These birds were seen on both the Roane County and Loudon County sides of the lake. Observers included Mike Ryon, Beth Schilling, Scott Somershoe, several of the authors, and other individuals. Extremely cold weather (particularly in the northeast) in the winter of 2013-14 pushed several species, including this one, farther south than usual. Red-necked grebes were observed on East Tennessee lakes in unprecedented numbers in February and March 2014.

Eared Grebe (Podiceps nigricollis - occasional): One record (one individual) from May 24, 1995, above Melton Hill Dam at approximately Clinch River mile 23.6 (kilometer 38) (observed by Jim Evans and Brenda O’Neal).

Anhinga (Anhinga anhinga — occasional): One record of one individual from June 2, 1994, at the ORNL Swan Pond. This bird was observed by David Cox, Jim Lane, and Brenda O’Neal. Recent conversations with Jim Lane, a wildlife professional with TWRA, leave little doubt as to this record. Not only was he emphatic that this bird was not a cormorant, but the logbook entry itself originally listed "cormorant" (meaning the much more common double-crested cormorant). That entry was crossed out and replaced with “American Anhinga," initialed, and dated the same day by Brenda O’Neal. The observers stated they were surprised it was not a cormorant. Mitchell et al. (1996) and Mann et al. (1997) previously reported the date of this observation as June 20, 1994, but that is a misprint; the correct date is June 2, 1994. East Tennessee anhinga records are extremely rare but have occurred previously, including a flyover in Hamilton County on October 11, 1987 (Dubke 1993). More recently, an adult female anhinga was photographed in Van Buren County on April 8, 2013. Anhingas are deemed "In Need of Management" in Tennessee.

American White Pelican (Pelecanus erythrorhynchos_occasional): A single white pelican was observed on Melton Hill Lake west of Gallaher Bend, in what is known as Reactor Cove (in the vicinity of a heron rookery) on April 26, 2010. Observers included Jim Evans, Neil Giffen, Mike Ryon, Beth Wade, and Murray Wade. There have been several additional, but undocumented, reports of both white and brown pelicans (Pelecanus occidentalis) on boundary waters of the ORR.

Least Bittern (Ixobrychus exilis-occasional): Recorded three times (seen and heard) by Neil Giffen at the K1007-P1 Pond-on July 1, 2012; May 16, 2013; and July 11, 2013. The timing of these records coincides well with the extensive growth of aquatic vegetation at this location related to remediation work at the P1 Pond. Least bitterns are deemed "In Need of Management” in Tennessee. 
Great Egret (Ardea alba—summer): Krumholz (1954) documented this species in the White Oak Creek study area. Mitchell et al. 1996 reported great egrets for Poplar Creek, ETTP Beaver Pond Complex, ORNL Swan Pond, upper and lower White Oak Lake, Freels Bend Land Bridge, and the K901-A Pond at ETTP. It has been documented in a number of locations on the ORR since that time, including White Oak Lake, ORNL Swan Pond, Intermediate Holding Pond (ORNL) and the K1007-P1 Pond at ETTP. This egret is most commonly seen on the ORR between July and September. Although most field guides list great egrets as a migrant in East Tennessee, it has been observed every month from March through November on the ORR. The only confirmed breeding of this species in East Tennessee at the time of Nicholson's (1997) breeding atlas project was in Hamilton County in 1990. This species has become much more common in East Tennessee since that time and is now a likely breeder on, or near, the ORR. Great egrets are deemed “In Need of Management” in Tennessee.

Snowy Egret (Egretta thula-occasional): A single snowy egret was recorded on the ORR at the ETTP Beaver Pond Complex in the spring of 1996 (Mitchell et al. 1996). Snowy egrets are deemed "In Need of Management” in Tennessee.

Little Blue Heron (Egretta caerulea-migrant): This species was first reported on the ORR by Krumholz (1954) in the White Oak Creek area. There were several sightings of probably one individual little blue heron in several wetlands across the ORR between July and September 1995 (Mitchell et al. 1996). In July 2010, single birds were recorded at the K1007P1 Pond (ETTP) and at the Intermediate Holding Pond off Lagoon Road at ORNL. The most recent sighting occurred August 9, 2013, at the Intermediate Holding Pond, adjacent to White Oak Creek mile 2.1 (kilometer 3.4). This immature bird was found by Kitty McCracken and subsequently observed and photographed (see Appendix F) by Kelly Roy and Trent Jett. Most, if not all, of these sightings have been of immature birds. Little blue herons are deemed "In Need of Management” in Tennessee.

Black-crowned Night-Heron (Nycticorax nycticorax —summer): Krumholz (1954) and Mitchell et al. (1996) recorded this species on the ORR, and it has been recorded in several areas of the ORR during PIF surveys. Consistent sightings have come from the Clinch River at Freels Bend (as recently as May 2014) and at Gallaher Bend. Other reliable locations for this species include several rookeries in the area, including one in Reactor Cove, one on White Oak Creek embayment, and one on Duct Island. This species was delisted in Tennessee in 1994, after having undergone status changes from "In Need of Management” to “Threatened” and back to "In Need Of Management” (Nicholson (1997). It is most commonly found from March to October.

White Ibis (Eudocemus albus — occasional): Howell (1958) reported an immature white ibis as a flyover southwest of the Solway Bridge over the Clinch River in August. The next documented record for this species on the ORR was also an immature white ibis, recorded at the Intermediate Holding Pond (ORNL) in July 2010. Two immature white ibises were observed in August 1996 in the City of Oak Ridge, approximately 0.9 mile $(1.5 \mathrm{~km})$ from the ORR boundary.

Bald Eagle (Haliaeetus leucocephalus - year-round): Bald eagle numbers are increasing on the ORR with growing evidence that they are year-round residents, although they can be difficult to find in the months of September through November. They have long been known as a winter visitor to the ORR, dating back to at least the early 1950s (Krumholz 1954). Mitchell et al. (1996) recorded bald eagles near Jones Island Road in 1994 and at Solway Bend, Bearden Creek (Clinch River), Hickory Creek Bend (Clinch River), Freels Bend Cabin, and Solway Bridge in 1996. In spring 2011, an eagle nest was found on Duct Island at a bend in Poplar Creek near ETTP in Roane County. The Duct Island eagle pair is known to have successfully fledged five eaglets from 2011 to 2014. A second ORR eagle nest was confirmed at the "Narrows" of Walker Branch on Melton Hill Reservoir in Anderson County on May 1, 2013, and one eaglet was observed on the nest on that date. In addition to the two nest locations, the 
Solway Bridge, Bearden Creek, and Brashear Island areas continue to produce fairly reliable bald eagle sightings. Interestingly, ORR bald eagle habitat suitability work conducted 20 years ago (Buehler 1994) ranked the Duct Island site as "unsuitable" eagle habitat (score of 0 out of 10), while the Walker Branch Narrows site was ranked good (habitat score of 6.1-8.0 out of 10). Bald eagles are deemed "In Need of Management” in Tennessee and were federally delisted in 2007.

Northern Harrier (Circus cyaneus - winter): Krumholz (1954) documented this species in the White Oak Lake study area, and Mitchell et al. (1996) recorded this species in the McNew Hollow/Hembree Marsh area, Raccoon Creek, 0800 Area along the Clinch River, and Freels Bend. It is a fairly regular winter species around ORR fields and wetlands, although Mitchell et al. (1996) recorded four specimens in September 1994, rather early in the season. The fields at Freels Bend, between November and April, likely offer the best viewing opportunities, although Chuck Estes, Mike Ryon, and Carole Gobert (eBird) have all observed harriers at the Heritage Center greenway (records in 2001, 2010, and 2014). Northern harriers are deemed "In Need of Management” in Tennessee.

Sharp-shinned Hawk (Accipiter striatus_-year-round): This uncommon hawk was documented in the White Oak Creek area of the ORR by Krumholz (1954) and Howell (1958), and a nest with young was also documented by Howell (1958) near the confluence of Poplar Creek with the Clinch River. Hardy (1991) recorded a nesting pair in a mature white pine plantation in 1989, and Mitchell et al. (1996) documented a nest near Raccoon Creek in 1994 (as reported to him in 1995 by Roger Kroodsma). Mitchell et al. (1996) recorded this species at numerous locations on the ORR, and it continues to be seen on a fairly regular basis. Though this hawk is a known breeding bird on the ORR, most observations occur outside the nesting season. Sharp-shinned hawks are deemed "In Need of Management" in Tennessee.

Cooper's Hawk (Accipiter cooperii-year-round): Krumholz (1954) documented this hawk in the White Oak Creek area, and Mitchell et al. (1996) reported it in several locations throughout the ORR. This hawk continues to be sighted on a fairly regular basis, particularly near fields and open areas, and it occurs yearround on the Reservation. This species was state-listed "Threatened" in 1975, downgraded to "In Need of Management” in 1994, and removed from listing in 2000.

Broad-winged Hawk (Buteo platypterus - summer): The broad-winged hawk is a fairly common migrant and summer resident in East Tennessee that is less common in the western part of the state (TWRA 2012). It occurs in both deciduous and mixed forest, mainly frequenting the canopy (Nicholson 1997). Krumholz (1954) documented this hawk in the White Oak Creek watershed, and Howell (1958) recorded it in nearby Melton Valley. This species has been recorded consistently on the ORR during PIF surveys in recent years, with the most sightings occurring in the Poplar Creek area (1997-2003, 2007). More recent observations have come from the North Boundary Greenway Trail (PIF survey, May 2013) and Lower Poplar Creek (incidental observation, July 2014). It is considered to be a probable breeder on the ORR, with observations occurring from March through September.

Virginia Rail (Rallus limicola — occasional): Other than historic records from Krumholz (1954), this species was not known to have been recorded on the ORR again until 2012, when Chuck Estes found them in the slough at the K1007-P1 Pond. Although most of Mr. Estes's observations have been in the slough, he observed them once along the north edge of the P1 Pond and has seen or heard them at least a half dozen times in total, including April 13, 2012; October 18, 2012; May 8, 2013; and late October 2013. He did not find them during several visits in February and March 2014. He has had good luck with them responding to playback, including playback of sora calls, and has heard at least two Virginia rails calling at the same time. Like the least bittern, the timing of this species at this location coincides with remediation efforts that have increased aquatic and riparian vegetation at the pond. 
Sora (Porzana carolina-migrant): Krumholz (1954) recorded soras on the ORR in the early 1950s, and they have been seen or heard at least a half dozen times on the ORR since 1997. As with the common gallinule, little is known of their presence or distribution on the Reservation in the interim. One of the most reliable locations for soras currently is the K1007-P1 pond and the adjoining slough, where they have been recorded as recently as December 2013. Soras have been recorded on the ORR in November, December, January, and April.

Common Gallinule (Gallinula galeata-occasional): This species was recently split from the common moorhen (Gallinula chloropus), which was formerly known as Florida gallinule. The official checklist of North American birds (AOU 1998; AOU 2013) recognizes both species (which have at least modest levels of vocal, physical, and genetic differences), with ornithologists leaning toward using galeata as the New World form and chloropus as the Old World form. There are three known occurrences of this species on the ORR. Krumolz (1954) reported two immature "Florida gallinules" on White Oak Lake in October 1952. Individual specimens were observed on a pond on Solway Bend in May 2008 and on the K1007-P1 Pond in October 2010. Little is known of their presence or distribution on the Reservation between Krumholz' record and the recent sightings. Common gallinules are deemed "In Need of Management” in Tennessee.

Sandhill Crane (Grus Canadensis - winter): This species is an occasional migrant through the area. A single sandhill crane was recorded on the ORR at Poplar Creek in March 1995 (Mitchell et al. 1996), and flyovers have been recorded at least six times since, in the months of December through March. Robert Brewer noted four birds over Chestnut Ridge in December 2003 (eBird). Flyovers in the vicinity of the Three Bend Area (Solway, Freels, and Gallaher Bends, collectively) have been recorded in recent years, and it is suspected that they periodically use the fields in that area during the winter. These individuals may be wandering from large groups that occupy Hiwassee Wildlife Refuge in winter. This refuge is south of Dayton, Tennessee, where the Hiwassee River empties into the Tennessee River, almost 50 miles (over $80 \mathrm{~km}$ ) to the southwest of the ORR.

Semipalmated Plover (Charadrius semipalmatus—occasional): Other than Krumholz' (1954) historic record, there is one record (of one individual) from September 9, 2002, at the K901-A Pond at ETTP (observed by Kitty McCracken and Kelly Roy).

Least Sandpiper (Calidris minutilla - occasional): One record (one individual) from August 29, 1996, at the sewage treatment aeration ponds south of White Oak Avenue and east of First Street on the ORNL campus (observed by Jim Evans and Kelly Roy).

White-rumped Sandpiper (Calidris fuscicollis - occasional): One record (one individual) from May 5, 1994, at the K901-A Pond at ETTP (observed by David Cox and Brenda O’Neal).

Caspian Tern (Hydroprogne caspia-occasional): Reports by Mitchell et al. (1996) and Mann et al. (1997) lack specific details, but it was a known "Reservation” bird at that time. One was observed flying on Melton Hill Reservoir near Freels Bend by David Buehler, Jim Evans, and others on April 9, 2014.

Forster's Tern (Sterna forsteri-occasional): One record of two Forster's terns from August 20, 1999, on Poplar Creek, one mile from the mouth, near the shallow mudflat that is visible at winter pool (observed by Kelly Roy).

Yellow-billed Cuckoo (Coccyzus americanus - summer): This species is widely distributed over forested areas of the ORR and has been previously reported by Krumholz (1954), Howell (1958), Anderson and Shugart (1974), Kroodsma (1982), and Mitchell et al. (1996). It is present spring through 
fall, with most observations occurring May through September, and it is consistently recorded on PIF routes in forested areas.

Barn Owl (Tyto alba-year-round): This widespread owl is rare on the ORR. They were known to utilize the old abandoned silo at Freels Bend before it was demolished between April and June 2006. The most recent known sighting (with photographs) comes from a natural cave opening on Bull Bluff on July 16, 2011 (observed by Jim Evans, Jason Richards, and Kelly Roy). At least three rehabilitated barn owls from the Clinch River Raptor Rehabilitation Center have been released on Solway and Freels Bend over the years. This species is deemed "In Need of Management” in Tennessee.

Northern Saw-whet Owl (Aegolius acadicus — historic): Recorded by Krumholz (1954), but no other known records for this owl on the ORR. Saw-whets occur in the Big South Fork National River and Recreation Area and in the Great Smoky Mountains National Park and sporadically at Seven Islands Refuge in Knox County. There are anecdotal records from the UT Arboretum, just off the ORR in Anderson County, and Murray Wade has seen this species once in the Hardin Valley area of Knox County. This species is deemed "Threatened” in Tennessee.

Red-headed Woodpecker (Melanerpes erythrocephalus - year-round): The red-headed woodpecker is a year-round resident in Tennessee and is most common in the western portion of the state, especially in winter. It breeds in open deciduous forest, river bottoms, groves of dead and dying trees, orchards, parks, and open wooded swamps with dead trees and stumps (TWRA 2012), and is a known breeder on the ORR (Roy et al. 2001). Krumholz (1954) documented this woodpecker on the ORR in the early 1950s, but the authors believe it was virtually absent from the Reservation from the early 1970s until the late 1990s, although Roger Kroodsma recalls seeing one in Haw Ridge Park in the mid-1980s. This species was extensively studied and documented on the ORR by Roy et al. (2001) from 1997 to 2001, and interestingly, its resurgence was believed to be linked, in part, to southern pine beetle outbreaks and the return of beaver (Castor canadensis) to the ORR. Most recent sightings of this species during PIF surveys have occurred at Dyllis Orchard/Raby Road (1998, 2002-03) and New Zion Patrol Road (2002, 2006). It has been observed multiple times since 2013 off Lagoon Road near SWSA-4, a solid waste storage area burial ground. Some of these sightings were at the entrance to cavities in dead pine snags. One of the most reliable areas to see this species on the ORR has been the ETTP Beaver Pond Complex. The redheaded woodpecker was listed "In Need of Management” in Tennessee from 1976 to 1994.

Yellow-bellied Sapsucker (Sphyrapicus varius - winter): The yellow-bellied sapsucker is a fairly common wintering species on the ORR. It has been previously reported by Krumholz (1954), in the Breeder Reactor Environmental Report (PMC 1977), and by Mitchell et al. (1996). It is known to occur October through April, though Hardy (1991) also reported two individuals in a loblolly pine plantation during the 1989 breeding season. Interestingly, it has been recorded twice in recent years (Dyllis Orchard on June 3, 2011, and Solway Bend on May 24, 2013) on ORR PIF surveys (Appendix A), although the only known breeding in Tennessee occurs at higher elevations, near the Tennessee-North Carolina border by the "appalachiensis" subspecies. In spite of these breeding season records, there is no evidence that this is a breeding bird on the ORR. The yellow-bellied sapsucker is deemed "In Need of Management" in Tennessee, no doubt, in part, because so little is known about the breeding biology of this bird within the state.

Hairy Woodpecker (Picoides villosus - year-round): Krumholz (1954) documented this woodpecker species in the White Oak Creek area, and Howell (1958) recorded it in Melton Valley. Anderson and Shugart (1974) recorded this species in the Walker Branch Watershed. Kroodsma (1984b) recorded this species in a forested area of the ORR during a breeding bird survey conducted between the mid- and late 1970s. Mitchell et al. (1996) recorded this species year-round on the ORR. This species is consistently 
recorded during PIF surveys in forested areas throughout the ORR, most often on the Dyllis Orchard, Solway Bend, and Poplar Creek routes.

Peregrine Falcon (Falco peregrinus — occasional): This uncommon migrant has been recorded at least three times on the ORR: on May 15, 1995, flying over the east end of the Reservation; on April 25, 1996, near Walker Branch; and on March 9, 2004, flying over the west end of ORNL. The first observation was by Roger Kroodsma, the second observation was by Fred Alsop and numerous members of a Breeding Bird Refresher Workshop, and the third observation was by Kelly Roy. Peregrine falcons are listed "Endangered" in Tennessee.

Olive-sided Flycatcher (Contopus cooperi-migrant): This rare ORR bird is known from several sightings in the 1990s including two at Freels Bend on May 12 and 15, 1995 (Mitchell et al. 1996; believed to be of the same bird), and one from a dead snag at the west end of SWSA-4 on August 20, 1999 (observed by Kelly Roy southwest of the intersection of Burial Ground Access Road and Trench 6 Access Road). Tennessee sightings of this species usually come from higher elevations along the eastern edge of the state. This species has been state-listed "In Need of Management" since 1994, though Nicholson (1997) and others believe its status warrants upgrading to "Threatened."

Eastern Wood-pewee (Contopus virens-summer): Krumholz (1954) recorded this species in the White Oak Creek area, and Howell (1958) recorded it twice in Melton Valley. Anderson and Shugart (1974) recorded this species during the breeding season in the Walker Branch Watershed. Eastern wood-pewees are recorded on a fairly routine basis during PIF surveys throughout the ORR. Although this species has shown an increase in population on the ORR since 1995 (Appendix B), its population is probably stable in Tennessee and decreasing range-wide (TWRA 2012).

Acadian Flycatcher (Empidonax virescens - summer): The Acadian flycatcher is an interior forest species common to the ORR. Howell (1958) first reported this flycatcher species on the Reservation in the fringe of bushes and small trees near the reservoir and small streams. Subsequent breeding season records for this species have come from upland hardwoods, according to the Breeder Reactor Environmental Report (PMC 1977), and from the Walker Branch Watershed according to Anderson and Shugart (1974). Kroodsma (1984b) recorded this species in low densities in interior forests during his 1977-81 studies. The Acadian flycatcher is currently a common species in mature forests throughout the ORR, especially in association with streams. It is a commonly recorded species during yearly PIF surveys, with the highest number of individuals observed in McNew Hollow, Poplar Creek, and Walker Branch. This flycatcher is one of a number of species on the Reservation that requires unfragmented interior forest and is one of the 28 species on the ORR listed by PIF to be of management concern (US Fish and Wildlife Service 2011) for the Appalachian Mountains sub-region (PIF 2012).

Willow Flycatcher (Empidonax trailii-summer): Willow flycatchers nest in scattered locations across Tennessee. They breed in moist, shrubby areas, often with standing or running water, and in willowdominated vegetation (TWRA 2012). Kroodsma first recorded this species on the ORR during the breeding season in the 1980s at two locations near Bethel Valley Road and near willows growing along a stream embayment at Freels Bend during the 1996 PIF survey. This species continues to be recorded in small numbers at Freels Bend, with the most recent observation during the PIF survey of 2013. Willow flycatchers also have been recorded outside of PIF surveys in the shrubby riparian zone adjacent to the K1007-P1 Pond (ETTP) from 2010 to 2013.

Western Kingbird (Tyrannus verticalis - occasional): One record (one individual) from August 26, 1998, at the fields just east of the Scarboro Facility, south of Bethel Valley Road between Pumphouse Road and the intersection of Bethel Valley Road and Illinois Avenue (observed by Jim Evans, Jason Mitchell, Kelly Roy, and Mike Ryon). Another record (one individual), just off the Reservation, from 
October 25, 2007, at Commerce Park, approximately 0.6 mile $(1 \mathrm{~km})$ north of the previous sighting (observed by Chris Welsh).

Loggerhead Shrike (Lanius ludovicianus_-year-round): Krumholz (1954) documented this species in the White Oak Creek area, and Howell (1958) reported two birds in the vicinity of the ORNL facilities on July 12, 1957. Mike Ryon reported (eBird) a single loggerhead shrike at the Heritage Center Greenway (adjacent to K1007-P1 Pond at ETTP) on July 1, 1991. One was observed on August 11, 1994, by Kelly Roy and others, approximately 400 yd southeast of the intersection of Pumphouse Road and Bethel Valley Road. Mitchell et al. (1996) observed loggerhead shrike(s) at Freels Bend on four different dates in November 1995. Despite the continued presence of apparently suitable habitat, one of the last known sightings of this species occurred at Freels Bend on April 24, 1996 (Mitchell et al. 1996). This species has been in widespread decline for decades and is currently deemed "In Need of Management" in Tennessee.

Yellow-throated Vireo (Vireo flavifrons - summer): The yellow-throated vireo is a fairly common summer bird on the ORR, found in both interior forests and woodland edges. This vireo was reported by Krumholz (1954) and Howell (1958) in areas with large trees near forest openings. This species was also recorded by Anderson and Shugart (1974) in some areas of the Walker Branch Watershed, and Kroodsma (1982) reported yellow-throated vireos during his power-line studies from 1975 to 1978. This species is still recorded fairly consistently during PIF surveys along several routes on the ORR, albeit in declining numbers since 1995 (Appendix B). This species prefers large, tall trees with open understory, openings, or woodland edges (Nicholson 1997), habitat that may have been more prevalent on the ORR historically than it is today.

Horned Lark (Eremophila alpestris_-occasional): Howell (1958) recorded a single flyover in 1957, and Jim Evans and Beth Schilling observed a flock of 25 horned larks inside the security fence at ETTP on January 11, 1996.

Black-capped Chickadee (Poecile atricapillus_-historic): Krumholz (1954), whose study covered a 3 year period from June 1950 to June 1953, is the only known person to have recorded this species on the ORR. He also recorded Carolina chickadees, presumably lessening the argument for a case of mistaken identity on his part. Though generally considered out-of-range, the authors accept his black-capped record (no doubt some will disagree), in part because this species is prone to irregular southward irruptions and slight shifts to the south during winter, and because he also recorded Carolinas. It is also worth noting that at the time of Krumholz's work, ornithologists recognized as many as 26 subspecies of chickadees (Bent 1964).

Brown-headed Nuthatch (Sitta pusilla-year-round): This species was first recorded on the ORR in September 1996, only a month after Beth Schilling discovered them in mature pines at the campground just above Melton Hill Dam in Loudon County. Roy et al. (2001) continued to document this species on the Reservation with numerous observations from 1996 to 2001. The appearance of this pine obligate species on the ORR is likely related to several factors, but most notable among them is the maturation of the ORR's loblolly pine (Pinus taeda) stands. This species was recorded on the 2001 PIF survey in the Dyllis Orchard/Raby Road area. It has been seen numerous times at the beaver ponds west of ETTP, as well as at the Melton Hill Dam campground and Clark Center Park-all locations from which it is still being reported on eBird. It is a known breeding bird on the ORR.

Bewick's Wren (Thyomanes bewickii-historic): Areas of historic reports of this species on the ORR include Freels Bend and White Oak Creek valley (Krumholz 1954, Howell 1958). Abandoned farmland and homesteads present at the establishment of the ORR provided abundant nesting habitat for this species. The succession of many areas into forested habitat has significantly decreased available habitat for this species on the ORR. The last record for this species on the ORR was in the 1970s (PMC 1977). 
This species was actually in decline in Tennessee by the 1940s and is now found, with any regularity, only in Rutherford County in Middle Tennessee (TWRA 2012). The Bewick's wren is listed as "Endangered" in Tennessee and is no longer found on the ORR.

Wood Thrush (Hylocichla mustelina-summer): The wood thrush is an interior forest species common on the ORR. There have been regular historical records of this species throughout the ORR, including White Oak Creek/Melton Valley, the Breeder Reactor site, and the Walker Branch Watershed (Krumholz 1954, Howell 1958, PMC 1977, Anderson and Shugart 1977). This species occurred in somewhat high densities (10-20 pairs/99 acres [40 ha]) in mixed forests on the ORR from 1977 through 1981 (Kroodsma 1984b). Though still common on forested ORR breeding bird routes, this species has been in a general decline since 1995 (Appendix B).

Varied Thrush (Ixoreus naevius - occasional): Known from one well-documented bird visiting a feeder at a residence on Whippoorwill Drive in Oak Ridge, April 13-17, 1996. This residential property abuts the DOE Reservation, and on at least one occasion, the bird was observed flying onto the ORR (Cushman and Cushman 1997). This was the third state record for varied thrush.

Worm-eating Warbler (Helmitheros vermivorum - summer): The worm-eating warbler is an infrequently recorded interior forest species in many areas of the Reservation. There are breeding season records from Howell (1958) and Kroodsma (1984b), and this species has been recorded sporadically on PIF surveys across the ORR since 1995. The most consistent PIF records have come from McNew Hollow, and the most recent records are from the New Zion Patrol Road area in 2011.

Louisiana Waterthrush (Parkesia motacilla-summer): This species, almost always associated with wooded streams during the breeding season, was recorded by Krumholz (1954) in the White Oak Creek study area and by Howell (1958) in Melton Valley. A pair was observed on Bear Creek in June 1996 and June 1997 (Mann et al. 1997). This species began showing up on PIF surveys in 2003 at McNew Hollow, Poplar Creek, and Walker Branch. The most consistent PIF records are for the McNew Hollow Road area (2003, 2004, 2006, 2010). There is one record from Gallaher Bend in 2011. There are continued anecdotal reports of this species for Walker Branch Watershed and Northwest Tributary.

Golden-winged Warbler (Vermivora chrysoptera-occasional): One record of one individual from May 5, 1998, at the far west end of Bear Creek Road, just east of Clinch River mile 14.5 (kilometer 23.3) (observed by Beth Schilling and Kelly Roy). This species is deemed "In Need of Management" in Tennessee.

Blue-winged Warbler (Vermivora cyanoptera-summer): Roger Kroodsma (1998, personal communication) recalled this species calling on territory near the intersection of Bear Creek Road and Highway 95 in the 1980s. Other than this report, there is little documentation of this species on the ORR before the mid-1990s. Mann et al. (1997) documented several sightings in 1995-96, and it has been turning up on breeding bird surveys since 1997 (Poplar Creek 1997-2013; Dyllis Orchard/Raby Road 1997, 1998, 2009, 2010; McNew Hollow 2007, 2009). Many recent sightings come from power-line corridors and areas of early successional vegetation, particularly on the Three Bend Area. TVA right-ofway maintenance and efforts to improve early successional habitat on the ORR have no doubt benefitted this species, which has been increasing as a Reservation bird since the mid-1990s (Appendix B). Bluewinged warblers are believed to have been present on the ORR in only very small numbers before the mid-1990s, and they are probably under-represented on today's breeding bird survey point counts. Bluewinged warblers are of "Regional Concern" to PIF.

Prothonotary Warbler (Protonotaria citrea-summer): This cavity nesting warbler is associated with swamps, streams, embayments, and wooded ponds, and was first reported on the ORR by Krumholz 
(1954) in the White Oak Creek watershed, 1950-53. Howell (1958) reported two birds in June 1957 adjacent to the Clinch River "near a small, willow-bordered pond $4.4 \mathrm{mi}$. from the Scarboro School along the A Road" (Freels Bend area) and another in July 1957 "1.6 mi. east of the White Wing Bridge on A Road” (near Melton Hill Dam today). Mann et al. (1997) documented breeding season records throughout the 1970s, 1980s, and 1990s. This species occurs in small numbers during PIF surveys in the Poplar Creek area (1997, 2000-01, 2005-07, 2011). Other fairly recent PIF records are for the Dyllis Orchard/Raby Road area (2005) and the New Zion Patrol Road area (2003, 2005-06). Informal survey records continue to show associations with beaver ponds west of ETTP, as well as along East Fork Poplar Creek, the Clinch River, and the 0800 area off Jones Island Road.

Hooded Warbler (Wilsonia citrina-summer): This interior forest warbler was reported by Howell (1958) in the White Oak Creek/Melton Valley area and on the slopes of nearby Haw Ridge and Copper Ridge. Anderson and Shugart (1974) found the bird to be abundant in the Walker Branch watershed during the breeding season. Kroodsma (1984b) reported the hooded warbler in low densities, while Hardy (1991) recorded it as one of the 10 most abundant breeding birds in mature loblolly pine plantations and one of the eight most abundant species in white pine plantations (as reported by Mann et al. 1997). This species was frequently recorded during PIF surveys from 1995 to 2011 at Dyllis Orchard/Raby Road, McNew Hollow, and New Zion Patrol Road. Hooded warblers also were noted in 2011 PIF surveys at Gallaher Bend, Park City Road, and Poplar Creek. This species is commonly seen and heard near "Katy's Kitchen” and the silo, east of Walker Branch. Hardy's observations notwithstanding, this species is unknown to the authors as showing any preference for pine stands over other mixed-forest habitats.

Cerulean Warbler (Setophaga cerulean-summer): J.C. Howell (1958) tentatively identified two singing male cerulean warblers by song only in Melton Valley in June and July 1957. He cautions, however, "While the songs of these two warblers seemed typical, there is the possibility that they could have been songs of Parula Warblers which were known to be present nearby.” This interior forest species formerly nested in the Walker Branch Watershed, where nine were observed from May through July of 1972 (Anderson and Shugart 1974). Five cerulean warblers were observed in the Walker Branch Watershed in April 1996, and two additional observations of this species were recorded that same month in a 3- to 5-year old regenerating clearcut loblolly stand near the Poplar Creek floodplain (Mitchell et al. 1996; Mann et al. 1997). Recent PIF survey records include New Zion Patrol Road (1999), Poplar Creek (2001, 2004) and Gallaher Bend (2005, 2006, 2009). The most recent eBird records are for April 10, 2013, at Freels Bend and May 25, 2013, at the North Boundary Greenway Trail. Cerulean warblers are deemed "In Need of Management" in Tennessee, and their population appears to be stable on the ORR (Table 1, Appendix B).

Yellow-throated Warbler (Setophaga dominica-summer): Krumholz (1954) documented this species in the White Oak Creek area, and Howell (1958) recorded this species during a study conducted in Melton Valley in 1957. Mitchell et al. (1996) recorded this species for the spring, summer, and fall seasons on the ORR. The yellow-throated warbler has been found throughout the ORR during PIF surveys. It has been recorded most consistently during PIF surveys at Dyllis Orchard/Raby Road, Gallaher Bend, McNew Hollow, and Poplar Creek.

Prairie Warbler (Setophaga discolor-summer): The prairie warbler has historically been one of the more common bird species recorded on the ORR (Krumholz 1954, Howell 1958, PMC 1977, Anderson et al. 1977, Kroodsma 1982, Kroodsma 1984a). This species is most commonly found in low elevation, dry, second-growth habitats with a dense groundcover, numerous shrubs, and an open canopy (Nicholson 1997). Most records on the ORR are in wide power line corridors and old fields. Hardy (1991) also reported a prairie warbler in a mature loblolly pine plantation during the breeding season. This species is present in numerous locations on the ORR where there is suitable habitat, and it has been recorded 
consistently during PIF surveys since 1995. However, observations of this species have shown a general decline since 1995 (Appendix B).

Bachman's Sparrow (Aimophila aestivalis_occasional, no records after 1982): This species was documented by Krumholz (1954) in the White Oak Lake study area. In addition, Howell (1958) reported nine observations on six dates at various locations on the ORR, including Freels Bend. The Bachman's sparrow was formerly present on the ORR in open grassy fields containing young eastern red cedars or pines, young pine plantations, and cedar barrens. Howell (1958) noted that the "pinewoods sparrow," as it was formerly known, "occurred in old fields grown up to bushes, rather than saplings and trees.” He also noted that it seemed to prefer sites that were somewhat eroded with areas bare of vegetation. The last documentation of this species on the ORR was of two singing territorial males northwest of the ORNL campus in 1982 (Kroodsma 1987). Bachman's sparrow is listed as "Endangered” in Tennessee.

Vesper Sparrow (Pooecetes gramineus - migrant): This sparrow, rarely seen during migration on the ORR, has been observed in the months of March, April, and October. The most recent known sightings are from October 30, 2006, at the NT3 Stream just west of the Y-12 facility and north of Bear Creek Road and on October 26, 2007, at the Checking Station on Bethel Valley Road. This sparrow is deemed "In Need of Management” in Tennessee.

Grasshopper Sparrow (Ammodramus savannarum —summer): Howell (1958) reported seven records of this species on the ORR, with six of those records being reported for, according to Mann et al. (1997), fields that were part of an agricultural complex containing Freels Bend. Kroodsma (1987) and Mitchell et al. (1996) also reported this species, with Mitchell et al. stating that nesting areas were associated with active hayfields where the mowing schedule had been modified to enhance nesting success. Chris Welsh reported (eBird) five birds on Freels Bend on May 23, 1998, and Mike Ryon reported (eBird) one bird there on April 13, 2005. Grasshopper sparrows were recorded in very low numbers during PIF surveys at Freels Bend in 1997, 1999, and 2000. There have been a few sightings outside these reports in recent years.

Henslow's Sparrow (Ammodramus henslowii-occasional): The breeding range of this species extends from the north-central United States eastward and south to Kentucky and northern Virginia. It appears to have extended its breeding range into central Tennessee in the late 1990s. Its habitat includes overgrown fields and meadows - often wet - with scattered low shrubs or saplings and standing dead vegetation from the previous season. The species has been declining mainly because of loss of habitat (TWRA 2012). Howell (1958) reported one singing male Henslow's sparrow at a survey point in the White Oak Creek/Melton Branch study area. Jim Evans and Jason Mitchell observed a Henslow's sparrow on Freels Bend on May 12, 2007, and Than Boves reported (eBird) a single Henslow's there on April 16, 2010. In spite of these observations, the authors have no definitive indication that this species is a breeding bird on the Reservation. Henslow's sparrow is deemed "In Need of Management” in Tennessee.

Lincoln's Sparrow (Melospiza lincolnii-occasional): Known from one record at Freels Bend on May 9, 2014; observed by Scott Somershoe, most of the authors, and several participants of a breeding bird refresher workshop.

Summer Tanager (Piranga rubra - summer): This species was recorded in the White Oak Lake study area by Krumholz (1954). On June 19, 1957, Howell (1958) found a nest with four young about 10 days old in a white oak (Quercus alba) and noted the species to be widespread throughout wooded sections of Melton Valley and both its ridges. This tanager was one of the more abundant species noted in the Breeder Reactor Environmental Report (PMC 1977), and 15 were reported for the Walker Branch survey (Anderson and Shugart 1974). Kroodsma (1984b) recorded this species at very high densities along power-line right-of-way edges in forested areas, but at much lower densities in interior forest. The 
summer tanager is now found throughout the ORR during PIF surveys. Consistent records come from Dyllis Orchard/Raby Road, Gallaher Bend, Poplar Creek, Solway Bend, and Walker Branch. Summer tanagers also were noted in PIF 2011 surveys at Natural Area 14 and New Zion Patrol Road.

Scarlet Tanager (Piranga olivacea-summer): Krumholz (1954) and Howell (1958) showed no records of this tanager in the White Oak Lake and Melton Valley areas. Anderson and Shugart (1974) noted this species to be common in the Walker Branch Watershed, with 21 observations during the breeding season. Kroodsma (1982) recorded 14 scarlet tanager territories, noting the species to be relatively unaffected by power-line corridors. Mitchell et al. (1996) recorded this species on the ORR during the spring, summer, and fall seasons. This species remains widespread throughout forested areas of the ORR, with recent records for all major PIF routes.

Blue Grosbeak (Passerina caerulea - summer): This species was first recorded on the ORR beside a road 2.8 miles (4.5 km) from the Scarboro School in July 1957 (Howell 1958). Anderson et al. (1977) recorded this species along transmission line corridors on the ORR in May and June 1974. Mitchell et al. (1996) also documented this species in the spring, summer, and fall during surveys of ORR protected species in 1994-96. The most consistent records for this species during PIF surveys have been at Freels Bend, although it can be found in many areas containing thickets and overgrown field edges such as Dyllis Orchard/Raby Road and the K1007-P1 Pond.

Dickcissel (Spiza americana — occasional): The distribution and abundance of this species sharply declines eastward of West Tennessee. Almost all East Tennessee records have been from the Ridge and Valley and have been concentrated in the most extensive agricultural areas in the northeast. Recent concentrations in northeastern Tennessee are consistent with the distribution of other grassland species in the region (e.g., grasshopper sparrow) (Nicholson 1997). Several birds have been recorded at Freels Bend, including one during the 1996 PIF survey. Although no dickcissels have been recorded on ORR breeding bird surveys since that time, two dickcissels were sighted in October 2010 at ETTP on the northwestern portion of the ORR in a pond riparian zone adjacent to a switchgrass (Panicum virgatum) field.

Red Crossbill (Loxia curvirostra-occasional): Known from one record of five birds flying over Haw Ridge Park on January 5, 2013, reported by Edmund LeGrand on a Knoxville Christmas Count.

Evening Grosbeak (Coccothraustes vespertinus_occasional): Known from one report of an individual bird, along Gum Branch Road approximately 0.75 mile $(1.2 \mathrm{~km})$ north of Bear Creek Road on April 12, 1994; observed by Beth Schilling, Kelly Roy, and possibly others. 


\section{SUMMARY}

Several bird species encountered on the ORR stand out as somewhat unusual or rare for this region; however, in the context of a 65 year period, these are probably not at all unusual. The nine species listed as "historic" in Appendix A have been absent from the Reservation for so long that it is doubtful when, if ever, they might again be encountered on the ORR. Certain other species, such as loggerhead shrike and Bachman's sparrow, have been absent so many years and are in such widespread decline that they, too, have a tentative status as future Reservation birds.

One hundred nine breeding bird species, along with an additional 11 "potential” breeding species, were identified out of the total 228 species found on the ORR. This total breeding bird list of 120 species consists of all "summer" $(n=51)$ and "year-round" $(n=63)$ residents, along with one "migrant," two "occasional," and three "historic" species (Appendix A). The blue-headed vireo is identified primarily as a "migrant" on the Reservation, but it has been recorded on breeding bird surveys, is known to breed nearby, and is, therefore, considered a potential breeding bird on the ORR. Bachman's sparrow ("occasional" status) was a Reservation breeding bird, but it has not been recorded in more than 30 years (this species might arguably fit better in the "historic" category). The least bittern, also with "occasional" status, has been observed during the breeding season and is considered a potential breeding bird on the ORR. Three "historic" species, considered to be potential breeding birds on the ORR in the 1950s, are the king rail (Rallus elegans), black-billed cuckoo (Coccyzus erythropthalmus), and Bewick's wren. Many sources consider East Tennessee to be in the breeding range for hooded mergansers (Lophodytes cucullatus), yet the authors have no evidence of this species breeding on the ORR. Though this duck has been recorded every month from November through June, it is considered a "winter" species, as the authors have very few May to June records.

Some grassland species, such as eastern meadowlark (Sturnella magna) and northern bobwhite, are in rather sharp decline on the ORR (Appendix B). This is a widespread trend, however, and efforts have been ongoing for at least a decade to preserve grassland species on the ORR. Those efforts have included prescribed burning, conversion to native warm season grasses (NWSG), disking to maintain early successional habitats, and altered mowing schedules to protect ground nesting birds. Thinning of ORR pine stands has been ongoing sporadically for decades. In recent years, however, we have been collaborating with UT and TWRA to emphasize grassland species management rather than thinning solely for timber production or fuel reduction. Additional right-of-way acreage on the ORR will be converted to NWSG in 2014 because of collaborations with TVA. Softening corridor edges, a recommendation of Brinkley and Buehler (2012), will also be employed whenever practical. This management practice involves thinning trees along corridor edges to release understory growth, which serves to "soften" the transition zone between corridor and forest. While some grassland species are in decline, there is little doubt that the above-mentioned efforts have contributed to ORR records for other species such as Henslow's and grasshopper sparrows.

Most, if not all, of the species that appear to have declined in population on the ORR since 1995 are experiencing similar trends on a larger scale. Other species are known to have shown significant declines since the 1950s, when Krumholz (1954), for example, reported an estimated 4,000 mallards (Anas platyrhynchos) and 1,000 black ducks (Anas rubripes) using White Oak Lake in the winter of 1952-53. Duck numbers such as these reported by Krumholz have not been seen on the ORR for at least the last 30 years.

Most bird species on the ORR seem to have stable or increasing populations, and new species continue to be found with some regularity. Of the 26 species determined by PIF to have decreasing populations in the Appalachian Region (Tables 1 and 2), only seven were found to have decreasing populations on the ORR (using a weight of evidence approach to analyzing slopes of trend lines). Without question, there are 
species not reported in Tables 1 and 2 that have seen fairly dramatic increases in population on the ORR during this study. Two such species are bald eagles and tree swallows (Tachycineta bicolor).

Despite some access restrictions on the ORR, eBird lists six areas of the Reservation as "hotspots," and three of these already have accumulated "public" bird species lists in excess of 100 species each. These include the Heritage Center Greenway, the Gallaher Bend/Clark Center Park area, and Freels Bend. The value of these areas to the public and the opportunities provided by all of the Reservation's greenways cannot be overstated. The tremendous diversity of avifauna on the Reservation is a testament to good stewardship and good land management practices. A species list of 228 birds could not have been achieved without the preservation of, maintenance of, and in some cases the creation of, a wide variety of habitat types.

Without question, there are bird species that easily could have gone undetected on the ORR for the last 65 years. Eurasian collared doves (Streptopelia decaocto) have been recorded in a number of areas surrounding the ORR and will likely be added to the Reservation species list, perhaps without welcome, in the near future. Golden eagles (Aquila chrysaetos), which have been recorded in Morgan and Cumberland counties, and Swainson's warbler (Limnothlypis swainsonii), known from several localities in Anderson County, are just two more examples of species that may have gone undetected on the Reservation. Certain other species, such as some of the rails, are extremely secretive and easily could go undetected. Nevertheless, it is hoped that the species list contained in this report will continue to grow with the addition of reliable, documented sightings of birds never before observed on the Oak Ridge Reservation. 


\section{REFERENCES}

American Ornithologists’ Union. 1998. Check-list of North American Birds, 7th ed. American Ornithologists' Union, Washington, D.C.

American Ornithologists’ Union. 2013. “Fifty-fourth supplement to the American Ornithologists’ Union Check-list of North American Birds.” The Auk 130, 558-571.

Anderson, S. H., K. H. Mann, and H. H. Shugart. 1977. "The Effect of Transmission-Line Corridors on Bird Populations.” American Midland Naturalist 97, 216-221.

Anderson, S. H., and H. H. Shugart Jr. 1974. "Habitat Selection of Breeding Birds in an East Tennessee Deciduous Forest.” Ecology 55, 828-837.

Bent, A. C. 1964. "Life Histories of North American Jays, Crows, and Titmice, Part II.” In Life Histories of North American Birds. Dover Publications, New York.

Brinkley, S. K., and D. A. Buehler. 2012. Monitoring Avian Communities in Native and Exotic Grasslands on the Oak Ridge Reservation, Tennessee. ORNL/TM-2012/135, Oak Ridge National Laboratory, Oak Ridge, Tenn.

Buehler, D. A. 1994. "Bald Eagle Habitat Suitability on Melton Hill Reservoir and the Clinch River.” In Environmental Sciences Division Publication No. 4248. ORNL/NERP-9, Oak Ridge National Laboratory, Oak Ridge, Tenn.

Cushman, J. H., and R. M. Cushman. 1997. “Third Varied Thrush Observed in Tennessee.” The Migrant 68(1), 10.

Dubke, L. H. 1993. “Anhinga over Amnicola Marsh, Hamilton County, Tennessee.” The Migrant 63(3), 58.

Giffen, N. R., J. W. Evans, and P. D. Parr. 2012. Wildlife Management Plan for the Oak Ridge Reservation. ORNL/TM-2012/387, Oak Ridge National Laboratory, Oak Ridge, Tenn.

Hanson, H. C. 1965. The Giant Canada Goose. Southern Illinois University Press. Carbondale.

Hardy, C. 1991. "A Comparison of bird Communities in Loblolly Pine Plantations on the Oak Ridge National Environmental Research Park.” MS thesis, The University of Tennessee, Knoxville.

Howell, J. C. 1958. Long-range ecological study of the Oak Ridge area. I. Observations on the summer birds in Melton Valley. Unpublished report, National Environmental Research Park files, Oak Ridge National Laboratory, Oak Ridge, Tenn.

Hughes, Joan F., and Sharon D. Thompson. 2013. “2012 Oak Ridge Reservation Annual Site Environmental Report.” DOE/ORO/2445, Oak Ridge National Laboratory, Oak Ridge, Tenn.

Kroodsma, R. L. 1982. “Bird Community Ecology on Power Line Corridors in East Tennessee.” Biological Conservation 23, 79-94.

Kroodsma, R. L. 1984a. "Ecological Factors Associated with the Degree of Edge Effect in Breeding Birds.” Journal of Wildlife Management 48, 418-425. 
Kroodsma, R. L. 1984b. “Effect of Edge on Breeding Forest Bird Species.” Wilson Bulletin 96, 426-436.

Kroodsma, R. L. 1987. Resource Management Plan for the Oak Ridge Reservation, Vol. 24: Threatened and Endangered Animal Species. ORNL/ESH-1/V24, Oak Ridge National Laboratory, Oak Ridge, Tenn.

Krumholz, L. A. 1954. An ecological survey of White Oak Creek, 1950-1953. ORO-587, Oak Ridge National Laboratory, Oak Ridge, Tenn.

Mann, L. K., J. M. Mitchell, J. W. Evans, J. D. Joslin, and M. D. Roedel. 1997. "Birds of the Oak Ridge Reservation.” The Migrant 68(3), 76-93.

Mitchell, J. M., E. R. Vail, J. W. Webb, J. W. Evans, A. L. King, and P. A. Hamlett. 1996. Survey of protected terrestrial vertebrates on the Oak Ridge Reservation, Final Report. ES/ER/TM-188-R1, Oak Ridge National Laboratory, Oak Ridge, Tenn.

Nicholson, C. P. 1997. Atlas of the Breeding Birds of Tennessee. University of Tennessee Press, Knoxville, Tenn.

Panjabi, A. O., P. J. Blancher, R. Dettmers, and K. V. Rosenberg, Version 2012. Partners in Flight Technical Series No. 3. Rocky Mountain Bird Observatory website:

http://www.rmbo.org/pubs/downloads/Handbook2012.pdf.

Parr, P. D., G. Byrd, and J. W. Johnston, Jr. 2012. Forest Management Plan for the Department of Energy Oak Ridge Reservation: An Interdisciplinary Approach for Managing a Heritage Resource. ORNL/TM2012/389, Oak Ridge National Laboratory, Oak Ridge, Tenn.

Parr, P. D., G. S. Byrd, J. W. Johnston, Jr., and N. R. Giffen. 2014. Forest Management Plan for the DOE Oak Ridge Reservation: An Interdisciplinary Approach for Managing a Heritage Resource. ORNL/TM2012/389 Rev. 1, Oak Ridge National Laboratory, Oak Ridge, Tenn.

Parr, P. D., and J. F. Hughes. 2006. Oak Ridge Reservation Physical Characteristics and Natural Resources. ORNL/TM-2006/110, Oak Ridge National Laboratory, Oak Ridge, Tenn.

Partners in Flight (PIF) Science Committee. 2012. "Species Assessment Database, version 2012.” http://rmbo.org/pifassessment. Accessed September 10, 2013.

Partners in Flight (PIF). 2013. http://www.partnersinflight.org. Accessed November 4, 2013.

Project Management Corporation (PMC). 1977. Clinch River Breeder Reactor Plant Environmental Report. Vol. 1. Oak Ridge, Tenn.

Roy, W. K., D. L. Combs, and J. W. Evans. 2004. "Movement and Harvest of Giant Canada Geese in East Tennessee.” The Migrant 75(4), 140-149.

Roy, W. K., J. W. Evans, and M. G. Ryon. 2001. “The Red-headed Woodpecker and Brown-headed Nuthatch on the Oak Ridge Reservation: Relationship to Recent Landscape Changes.” The Migrant 72(1), $1-12$.

Smith, T. M. and H. H. Shugart. 1987. "Territory Size Variation in the Ovenbird: The Role of Habitat Structure.” Ecology 68, 695-704. 
Sullivan, B. L., C. L. Wood, M. J. Iliff, R. E. Bonney, D. Fink, and S. Kelling. 2009. “eBird: A Citizenbased Bird Observation Network in the Biological Sciences.” Biological Conservation 142, 2282-2292. http://eBird.org.

Tennessee Wildlife Resources Agency (TWRA). 2012. “Tennessee’s Watchable Wildlife.” http://www.tnwatchablewildlife.org/.

TN-Bird. An email discussion group about Tennessee birds owned by the Tennessee Ornithological Society. http://www.tnbirds.org/birding_tn.htm.

US Fish and Wildlife Service. 2011. "Birds of Management Concern and Focal Species, US Fish and Wildlife Service, Migratory Bird Program.”

http://www.fws.gov/migratorybirds/CurrentBirdIssues/Management/BMC.html.

Washington-Allen, R. A., T. L. Ashwood, S. W. Christensen, H. Offerman, and P. Scarbrough Luther. 1995. Terrestrial Mapping of the Oak Ridge Reservation: Phase I. ES/ER/TM-152, Oak Ridge National Laboratory, Oak Ridge, Tenn. 

APPENDIX A. BIRD SPECIES RECORDED ON THE OAK RIDGE RESERVATION (1950-2014) 

APPENDIX A. BIRD SPECIES RECORDED ON THE OAK RIDGE RESERVATION (1950-2014) ${ }^{a}$

\begin{tabular}{|c|c|c|c|c|c|c|}
\hline \multirow{2}{*}{ Scientific name } & \multirow{2}{*}{ Common name } & \multirow{2}{*}{ Season $^{b}$} & \multirow{2}{*}{$\begin{array}{l}\text { PIF } \\
\text { Obs }^{c}\end{array}$} & \multicolumn{3}{|c|}{ Status $^{d}$} \\
\hline & & & & Federal & State & PIF \\
\hline \multicolumn{7}{|c|}{ Swans, Geese, and Ducks } \\
\hline Anser albifrons & greater white-fronted goose & occasional & 0 & & & \\
\hline Chen caerulescens & snow goose & migrant & 0 & & & \\
\hline Chen rossii & Ross's goose & occasional & 0 & & & \\
\hline Branta canadensis & Canada goose $^{e}$ & year-round & 581 & $\mathrm{MC}$ & & \\
\hline Cygnus olor & mute swan (domestic) ${ }^{e}$ & year-round & 0 & & & \\
\hline Aix sponsa & wood duck ${ }^{e}$ & year-round & 25 & $\mathrm{MC}$ & & \\
\hline Anas strepera & gadwall & winter & 0 & $\mathrm{MC}$ & & \\
\hline Anas americana & American wigeon & winter & 0 & $\mathrm{MC}$ & & \\
\hline Anas rubripes & American black duck & winter & 0 & $\mathrm{MC}$ & & \\
\hline Anas platyrhynchos & mallard $^{e}$ & year-round & 3 & $\mathrm{MC}$ & & \\
\hline Anas discors & blue-winged teal & migrant & 0 & $\mathrm{MC}$ & & \\
\hline Anas clypeata & northern shoveler & winter & 0 & $\mathrm{MC}$ & & \\
\hline Anas acuta & northern pintail & migrant & 0 & $\mathrm{MC}$ & & \\
\hline Anas crecca & green-winged teal & winter & 0 & $\mathrm{MC}$ & & \\
\hline Aythya valisineria & canvasback & migrant & 0 & $\mathrm{MC}$ & & \\
\hline Aythya americana & redhead & winter & 0 & $\mathrm{MC}$ & & \\
\hline Aythya collaris & ring-necked duck & winter & 0 & $\mathrm{MC}$ & & \\
\hline Aythya marila & greater scaup & occasional & 0 & $\mathrm{MC}$ & & \\
\hline Aythya affinis & lesser scaup & winter & 0 & $\mathrm{MC}$ & & \\
\hline Melanitta fusca & white-winged scoter & occasional & 0 & MC & & \\
\hline Bucephala albeola & bufflehead & winter & 0 & & & \\
\hline Bucephala clangula & common goldeneye & winter & 0 & $\mathrm{MC}$ & & \\
\hline Lophodytes cucullatus & hooded merganser & winter & 0 & & & \\
\hline Mergus merganser & common merganser & occasional & 0 & & & \\
\hline Mergus serrator & red-breasted merganser & migrant & 0 & & & \\
\hline Oxyura jamaicensus & ruddy duck & winter & 0 & $\mathrm{MC}$ & & \\
\hline
\end{tabular}




\begin{tabular}{|c|c|c|c|c|c|c|}
\hline \multirow{2}{*}{ Scientific name } & \multirow{2}{*}{ Common name } & \multirow{2}{*}{ Season $^{b}$} & \multirow{2}{*}{$\begin{array}{l}\text { PIF } \\
\text { Obs }^{c}\end{array}$} & \multicolumn{3}{|c|}{ Status $^{d}$} \\
\hline & & & & Federal & State & $\overline{\text { PIF }}$ \\
\hline \multicolumn{7}{|c|}{ Grouse, Turkey, and Quail } \\
\hline Colinus virginianus & northern bobwhite $^{e}$ & year-round & 225 & & & $\mathrm{RC}$ \\
\hline Bonasa umbellus & ruffed grouse $^{e}$ & year-round & 0 & & & \\
\hline Meleagris gallopavo & wild turkey $^{e}$ & year-round & 170 & & & \\
\hline \multicolumn{7}{|c|}{ Loons } \\
\hline Gavia immer & common loon & migrant & 0 & & & \\
\hline \multicolumn{7}{|c|}{ Grebes } \\
\hline Podilymbus podiceps & pied-billed grebe $^{t}$ & year-round & 0 & MC & & \\
\hline Podiceps auritus & horned grebe & winter & 0 & $\mathrm{MC}$ & & \\
\hline Podiceps nigricollis & eared grebe & occasional & 0 & & & \\
\hline Podiceps grisegena & red-necked grebe & occasional & 0 & & & \\
\hline \multicolumn{7}{|c|}{ Cormorants } \\
\hline Phalacrocorax auritus & double-crested cormorant $^{e}$ & year-round & 84 & MC & & \\
\hline \multicolumn{7}{|c|}{ Darters } \\
\hline Anhinga anhinga & anhinga & occasional & 0 & & NM & \\
\hline \multicolumn{7}{|c|}{ Pelicans } \\
\hline Pelecanus erythrorhynchos & American white pelican & occasional & 0 & & & \\
\hline \multicolumn{7}{|c|}{ Bitterns and Herons } \\
\hline Ixobrychus exilis & least bittern ${ }^{f}$ & occasional & 0 & $\mathrm{MC}$ & NM & \\
\hline Ardea herodias & great blue heron $^{e}$ & year-round & 340 & & & \\
\hline Ardea alba & great egret $^{f}$ & summer & 4 & & NM & \\
\hline Egretta thula & snowy egret & occasional & 0 & $\mathrm{MC}$ & NM & \\
\hline Egretta caerulea & little blue heron & migrant & 0 & $\mathrm{MC}$ & NM & \\
\hline Butorides virescens & green heron $^{e}$ & summer & 18 & & & \\
\hline Nycticorax nycticorax & black-crowned night heron $^{e}$ & summer & 115 & $\mathrm{MC}$ & & \\
\hline Eudocemus albus & white ibis & occasional & 0 & & & \\
\hline \multicolumn{7}{|c|}{ Vultures } \\
\hline Coragyps atratus & black vulture $^{e}$ & year-round & 100 & & & \\
\hline Cathartes aura & turkey vulture $^{e}$ & year-round & 27 & & & \\
\hline
\end{tabular}




\begin{tabular}{|c|c|c|c|c|c|c|}
\hline \multirow{2}{*}{ Scientific name } & \multirow{2}{*}{ Common name } & \multirow{2}{*}{ Season $^{b}$} & \multirow{2}{*}{$\begin{array}{c}\text { PIF } \\
\text { Obs }^{c}\end{array}$} & \multicolumn{3}{|c|}{ Status $^{d}$} \\
\hline & & & & Federal & State & $\overline{\text { PIF }}$ \\
\hline \multicolumn{7}{|c|}{ Kites, Hawks, Eagles, and Allies } \\
\hline Pandion haliaetus & osprey $^{e}$ & year-round & 53 & & & \\
\hline Haliaeetus leucocephalus & bald eagle $^{e}$ & year-round & 0 & $\mathrm{MC}^{g}$ & NM & \\
\hline Circus cyaneus & northern harrier & winter & 0 & & NM & \\
\hline Accipiter striatus & sharp-shinned hawk $^{e}$ & year-round & 4 & $\mathrm{MC}$ & NM & \\
\hline Accipiter cooperii & Cooper's hawk ${ }^{e}$ & year-round & 7 & & & \\
\hline Buteo lineatus & red-shouldered hawk ${ }^{e}$ & year-round & 26 & & & \\
\hline Buteo platypterus & broad-winged hawk $^{e}$ & summer & 6 & & & \\
\hline Buteo jamaicensis & red-tailed hawk ${ }^{e}$ & year-round & 61 & & & \\
\hline Buteo lagopus & rough-legged hawk & historic & 0 & & & \\
\hline \multicolumn{7}{|c|}{ Rails, Gallinules, and Coots } \\
\hline Rallus elegans & king rail $^{f}$ & historic & 0 & MC & NM & \\
\hline Rallus limicola & Virginia rail & migrant & 0 & $\mathrm{MC}$ & & \\
\hline Porzana carolina & sora & migrant & 0 & $\mathrm{MC}$ & & \\
\hline Gallinula galeata & common gallinule & occasional & 0 & & NM & \\
\hline Fulica americana & 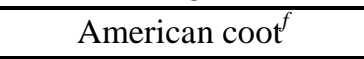 & year-round & 0 & $\mathrm{MC}$ & & \\
\hline \multicolumn{7}{|c|}{ Cranes } \\
\hline Grus canadensis & sandhill crane & winter & 0 & $\mathrm{MC}$ & & \\
\hline \multicolumn{7}{|c|}{ Plovers } \\
\hline Charadrius semipalmatus & semipalmated plover & occasional & 0 & $\mathrm{MC}$ & & \\
\hline Charadrius vociferus & killdeer $^{e}$ & year-round & 37 & & & \\
\hline \multicolumn{7}{|c|}{ Sandpipers and Allies } \\
\hline Actitus macularius & spotted sandpiper & migrant & 0 & & & \\
\hline Tringa solitaria & solitary sandpiper & migrant & 0 & $\mathrm{MC}$ & & \\
\hline Tringa melanoleuca & greater yellowlegs & migrant & 0 & & & \\
\hline Tringa flavipes & lesser yellowlegs & migrant & 0 & $\mathrm{MC}$ & & \\
\hline Calidris minutilla & least sandpiper & occasional & 0 & & & \\
\hline Calidris fuscicollis & white-rumped sandpiper & occasional & 0 & & & \\
\hline Calidris melanotos & pectoral sandpiper & occasional & 0 & & & \\
\hline
\end{tabular}




\begin{tabular}{|c|c|c|c|c|c|c|}
\hline \multirow{2}{*}{ Scientific name } & \multirow{2}{*}{ Common name } & \multirow{2}{*}{ Season $^{b}$} & \multirow{2}{*}{$\begin{array}{l}\text { PIF } \\
\text { Obs }^{c}\end{array}$} & \multicolumn{3}{|c|}{ Status $^{d}$} \\
\hline & & & & Federal & State & PIF \\
\hline Gallinago gallinago & common snipe & winter & 0 & & & \\
\hline Scolopax minor & American woodcock $^{e}$ & year-round & 0 & MC & & \\
\hline \multicolumn{7}{|c|}{ Gulls and Terns } \\
\hline Chroicocephalus philadelphia & Bonaparte’s gull & winter & 0 & & & \\
\hline Larus delawarensis & ring-billed gull & winter & 1 & & & \\
\hline Larus argentatus & herring gull & occasional & 0 & & & \\
\hline Hydroprogne caspia & Caspian tern & occasional & 0 & & & \\
\hline Sterna forsteri & Forster's tern & occasional & 0 & & & \\
\hline \multicolumn{7}{|c|}{ Pigeons and Doves } \\
\hline Columba livia & rock pigeon $^{e}$ & year-round & 0 & & & \\
\hline Zenaida macroura & mourning dove $e^{e}$ & year-round & 483 & $\mathrm{MC}$ & & \\
\hline \multicolumn{7}{|c|}{ Cuckoos } \\
\hline Coccyzus americanus & yellow-billed cuckoo $^{e}$ & summer & 689 & & & \\
\hline Coccyzus erythropthalmus & black-billed cuckoo $^{\dagger}$ & historic & 0 & & & $\mathrm{RC}$ \\
\hline \multicolumn{7}{|c|}{ Owls } \\
\hline Tyto alba & barn owl ${ }^{e}$ & year-round & 0 & & NM & \\
\hline Megascops asio & eastern screech owl ${ }^{e}$ & year-round & 1 & & & \\
\hline Bubo virginianus & great horned owl $^{e}$ & year-round & 1 & & & \\
\hline Strix varia & barred owl $^{e}$ & year-round & 16 & & & \\
\hline Asio flammeus & short-eared owl & historic & 0 & $\mathrm{MC}$ & & \\
\hline Aegolius acadicus & northern saw-whet owl & historic & 0 & $\mathrm{MC}$ & $\mathrm{T}$ & $\mathrm{RC}$ \\
\hline \multicolumn{7}{|c|}{ Goatsuckers } \\
\hline Chordeiles minor & common nighthawk ${ }^{f}$ & summer & 2 & & & \\
\hline Caprimulgus carolinensis & chuck-will's-widow $^{e}$ & summer & 13 & $\mathrm{MC}$ & & $\mathrm{RC}$ \\
\hline Caprimulgus vociferus & eastern whip-poor-will ${ }^{e}$ & summer & 12 & & & $\mathrm{RC}$ \\
\hline \multicolumn{7}{|c|}{ Swifts } \\
\hline Chaetura pelagica & chimney swift $^{e}$ & summer & 83 & & & $\mathrm{RC}$ \\
\hline \multicolumn{7}{|c|}{ Hummingbirds } \\
\hline Archilochus colubris & ruby-throated hummingbird $^{e}$ & summer & 102 & & & \\
\hline
\end{tabular}




\begin{tabular}{|c|c|c|c|c|c|c|}
\hline \multirow{2}{*}{ Scientific name } & \multirow{2}{*}{ Common name } & \multirow{2}{*}{ Season $^{b}$} & \multirow{2}{*}{$\begin{array}{l}\text { PIF } \\
\text { Obs }^{c}\end{array}$} & \multicolumn{3}{|c|}{ Status $^{d}$} \\
\hline & & & & Federal & State & PIF \\
\hline \multicolumn{7}{|c|}{ Kingfishers } \\
\hline Megaceryle alcyon & belted kingfisher $^{e}$ & year-round & 36 & & & $\mathrm{RC}$ \\
\hline \multicolumn{7}{|c|}{ Woodpeckers } \\
\hline Melanerpes erythrocephalus & red-headed woodpecker ${ }^{e}$ & year-round & 7 & $\mathrm{MC}$ & & \\
\hline Melanerpes carolinus & red-bellied woodpecker $^{e}$ & year-round & 846 & & & \\
\hline Sphyrapicus varius & yellow-bellied sapsucker & winter & 2 & $\mathrm{MC}$ & NM & \\
\hline Picoides pubescens & downy woodpecker ${ }^{e}$ & year-round & 361 & & & \\
\hline Picoides villosus & hairy woodpecker $^{e}$ & year-round & 238 & & & \\
\hline Colaptes auratus & northern flicker $^{e}$ & year-round & 138 & & & $\mathrm{RC}$ \\
\hline Dryocopus pileatus & pileated woodpecker $^{e}$ & year-round & 250 & & & \\
\hline \multicolumn{7}{|c|}{ Falcons } \\
\hline Falco sparverius & American kestrel $^{e}$ & year-round & 10 & $\mathrm{MC}$ & & $\mathrm{RC}$ \\
\hline Falco columbarius & merlin & migrant & 0 & & & \\
\hline Falco peregrinus & peregrine falcon & occasional & 0 & $\mathrm{MC}^{h}$ & $\mathrm{E}$ & $\mathrm{RC}$ \\
\hline \multicolumn{7}{|c|}{ Tyrant Flycatchers } \\
\hline Contopus cooperi & olive-sided flycatcher & migrant & 0 & $\mathrm{MC}$ & NM & $\mathrm{RC}$ \\
\hline Contopus virens & eastern wood-pewee $^{e}$ & summer & 61 & & & $\mathrm{RC}$ \\
\hline Empidonax virescens & Acadian flycatcher $^{e}$ & summer & 474 & & & $\mathrm{RC}$ \\
\hline Empidonax trailii & willow flycatcher $^{e}$ & summer & 11 & & & \\
\hline Sayornis phoebe & eastern phoebe $^{e}$ & year-round & 165 & & & \\
\hline Myiarchus crinitus & great-crested flycatcher $^{e}$ & summer & 132 & & & \\
\hline Tyrannus verticalis & western kingbird & occasional & 0 & & & \\
\hline Tyrannus tyrannus & eastern kingbird $^{e}$ & summer & 60 & & & \\
\hline \multicolumn{7}{|c|}{ Shrikes } \\
\hline Lanius ludovicianus & loggerhead shrike $^{e}$ & year-round & 0 & & NM & $\mathrm{RC}$ \\
\hline \multicolumn{7}{|c|}{ Vireos } \\
\hline Vireo griseus & white-eyed vireo $^{e}$ & summer & 431 & & & \\
\hline Vireo flavifrons & yellow-throated vireo $^{e}$ & summer & 90 & & & $\mathrm{RC}$ \\
\hline Vireo solitarius & blue-headed vireo $^{f}$ & migrant & 4 & & & \\
\hline
\end{tabular}




\begin{tabular}{|c|c|c|c|c|c|c|}
\hline \multirow{2}{*}{ Scientific name } & \multirow{2}{*}{ Common name } & \multirow{2}{*}{ Season $^{b}$} & \multirow{2}{*}{$\begin{array}{l}\text { PIF } \\
\text { Obs }^{c}\end{array}$} & \multicolumn{3}{|c|}{ Status $^{d}$} \\
\hline & & & & Federal & State & PIF \\
\hline Vireo gilvus & warbling vireo & occasional & 0 & & & \\
\hline Vireo olivaceus & red-eyed vireo $^{e}$ & summer & 3071 & & & \\
\hline \multicolumn{7}{|c|}{ Jays and Crows } \\
\hline Cyannocitta cristata & blue jay $^{e}$ & year-round & 870 & & & \\
\hline Corvus brachyrhynchos & 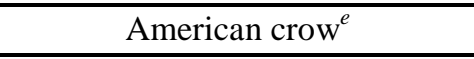 & year-round & 1575 & & & \\
\hline \multicolumn{7}{|c|}{ Lark } \\
\hline Eremophila alpestris & horned lark & occasional & 0 & & & \\
\hline \multicolumn{7}{|c|}{ Swallows } \\
\hline Progne subis & purple martin $^{e}$ & summer & 9 & & & $\mathrm{RC}$ \\
\hline Tachycineta bicolor & tree swallow $^{e}$ & summer & 127 & & & \\
\hline Stelgidopteryx serripennis & northern rough-winged swallow ${ }^{e}$ & summer & 77 & & & \\
\hline Riparia riparia & bank swallow & migrant & 0 & & & \\
\hline Petrochelidon pyrrhonota & cliff swallow $^{e}$ & summer & 4 & & & \\
\hline Hirundo rustica & barn swallow $^{e}$ & summer & 289 & & & $\mathrm{RC}$ \\
\hline \multicolumn{7}{|c|}{ Titmice and Chickadees } \\
\hline Poecile carolinensis & Carolina chickadee $^{e}$ & year-round & 1136 & & & \\
\hline Poecile atricapillus & black-capped chickadee & historic & 0 & $\mathrm{MC}$ & $\mathrm{NM}$ & \\
\hline Baeolophus bicolor & tufted titmouse $^{e}$ & year-round & 1325 & & & \\
\hline \multicolumn{7}{|c|}{ Nuthatches } \\
\hline Sitta canadensis & red-breasted nuthatch & winter & 0 & & & \\
\hline Sitta carolinensis & white-breasted nuthatch ${ }^{e}$ & year-round & 421 & & & \\
\hline Sitta pusilla & brown-headed nuthatch $^{e}$ & year-round & 2 & $\mathrm{MC}$ & & \\
\hline \multicolumn{7}{|c|}{ Creepers } \\
\hline Certhia americana & brown creeper & winter & 0 & & & \\
\hline \multicolumn{7}{|c|}{ Wrens } \\
\hline Troglodytes aedon & house wren $^{e}$ & summer & 3 & & & \\
\hline Troglodytes hiemalis & winter wren & winter & 0 & & & \\
\hline Cistothorus platensis & sedge wren & occasional & 0 & $\mathrm{MC}$ & & \\
\hline Cistothorus palustris & marsh wren & occasional & 0 & & & \\
\hline
\end{tabular}




\begin{tabular}{|c|c|c|c|c|c|c|}
\hline \multirow{2}{*}{ Scientific name } & \multirow{2}{*}{ Common name } & \multirow{2}{*}{ Season $^{b}$} & \multirow{2}{*}{$\begin{array}{c}\text { PIF } \\
\text { Obs }^{c}\end{array}$} & \multicolumn{3}{|c|}{ Status $^{d}$} \\
\hline & & & & Federal & State & $\overline{\text { PIF }}$ \\
\hline Thryothorus ludovicianus & Carolina wren $^{e}$ & year-round & 1048 & & & \\
\hline Thryomanes bewickii & Bewick’s wren $^{f}$ & historic & 0 & $\mathrm{MC}$ & $\mathrm{E}$ & \\
\hline \multicolumn{7}{|c|}{ Kinglets, Gnatcatchers, and Thrushes } \\
\hline Polioptila caerulea & blue-gray gnatcatcher $^{e}$ & summer & 876 & & & \\
\hline Regulus satrapa & golden-crowned kinglet & winter & 0 & & & \\
\hline Regulus calendula & ruby-crowned kinglet & winter & 0 & & & \\
\hline Siala sialis & eastern bluebird $^{e}$ & year-round & 244 & & & \\
\hline Catharus fuscescens & veery & migrant & 0 & & & \\
\hline Catharus ustulatus & Swainson’s thrush & migrant & 2 & & & \\
\hline Catharus guttatus & hermit thrush & winter & 0 & & & \\
\hline Hylocichla mustelina & wood thrush $^{e}$ & summer & 1167 & MC & & $\mathrm{RC}$ \\
\hline Turdus migratorius & American robin $^{e}$ & year-round & 86 & & & \\
\hline Ixoreus naevius & varied thrush & occasional & 0 & & & \\
\hline \multicolumn{7}{|c|}{ Thrashers and Mockingbirds } \\
\hline Dumetella carolinensis & gray catbird $^{e}$ & summer & 18 & & & \\
\hline Toxostoma rufum & brown thrasher $^{e}$ & year-round & 104 & & & $\mathrm{RC}$ \\
\hline Mimus polyglottos & northern mockingbird $^{e}$ & year-round & 85 & & & \\
\hline \multicolumn{7}{|c|}{ Starlings } \\
\hline Sturnus vulgaris & European starling $^{e}$ & year-round & 202 & & & \\
\hline \multicolumn{7}{|c|}{ Pipits and Wagtails } \\
\hline Anthus rubescens & American pipit & occasional & 0 & & & \\
\hline \multicolumn{7}{|c|}{ Waxwings } \\
\hline Bombycilla cedrorum & cedar waxwing ${ }^{e}$ & year-round & 45 & & & \\
\hline \multicolumn{7}{|c|}{ Wood-Warblers } \\
\hline Seiurus aurocapilla & ovenbird $^{e}$ & summer & 543 & & & \\
\hline Helmitheros vermivorus & worm-eating warbler $^{e}$ & summer & 77 & $\mathrm{MC}$ & & $\mathrm{RC}$ \\
\hline Parkesia motacilla & Louisiana waterthrush $^{e}$ & summer & 22 & $\mathrm{MC}$ & & $\mathrm{RC}$ \\
\hline Parkesia noveboracensis & northern waterthrush & migrant & 2 & & & \\
\hline Vermivora chrysotera & golden-winged warbler & occasional & 0 & $\mathrm{MC}$ & NM & $\mathrm{RC}$ \\
\hline
\end{tabular}




\begin{tabular}{|c|c|c|c|c|c|c|}
\hline \multirow{2}{*}{ Scientific name } & \multirow{2}{*}{ Common name } & \multirow{2}{*}{ Season $^{b}$} & \multirow{2}{*}{$\begin{array}{l}\text { PIF } \\
\text { Obs }^{c}\end{array}$} & \multicolumn{3}{|c|}{ Status $^{d}$} \\
\hline & & & & Federal & State & $\overline{\text { PIF }}$ \\
\hline Vermivora cyanoptera & blue-winged warbler $^{e}$ & summer & 27 & $\mathrm{MC}$ & & $\mathrm{RC}$ \\
\hline Mniotilta varia & black-and-white warbler $^{e}$ & summer & 3 & & & $\mathrm{RC}$ \\
\hline Protonotaria citrea & prothonotary warbler $^{e}$ & summer & 17 & $\mathrm{MC}$ & & \\
\hline Oreothlypis peregrina & Tennessee warbler & migrant & 0 & & & \\
\hline Oreothlypis ruficapilla & Nashville warbler & migrant & 0 & & & \\
\hline Geothlypis formosa & Kentucky warbler $^{e}$ & summer & 175 & $\mathrm{MC}$ & & $\mathrm{RC}$ \\
\hline Geothlypis trichas & common yellowthroat $^{e}$ & summer & 383 & & & \\
\hline Setophaga citrina & hooded warbler $^{e}$ & summer & 318 & & & \\
\hline Setophaga ruticilla & American redstart $^{e}$ & summer & 5 & & & \\
\hline Setophaga kirtlandii & Kirtland's warbler & historic & 0 & $\mathrm{E}$ & & \\
\hline Setophaga tigrina & Cape May warbler & migrant & 0 & & & \\
\hline Setophaga cerulea & cerulean warbler $^{f}$ & summer & 7 & $\mathrm{MC}$ & NM & $\mathrm{RC}$ \\
\hline Setophaga americana & northern parula ${ }^{e}$ & summer & 183 & & & \\
\hline Setophaga magnolia & magnolia warbler & migrant & 0 & & & \\
\hline Setophaga castanea & bay-breasted warbler & migrant & 1 & $\mathrm{MC}$ & & \\
\hline Setophaga fusca & blackburnian warbler & migrant & 0 & & & \\
\hline Setophaga petechia & yellow warbler ${ }^{e}$ & summer & 10 & & & \\
\hline Setophaga pensylvanica & chestnut-sided warbler & migrant & 0 & & & \\
\hline Setophaga striata & blackpoll warbler & migrant & 0 & & & \\
\hline Setophaga caerulescens & black-throated blue warbler & occasional & 0 & & & \\
\hline Setophaga palmarum & palm warbler & migrant & 0 & & & \\
\hline Setophaga pinus & pine warbler $^{e}$ & year-round & 325 & & & \\
\hline Setophaga coronata & yellow-rumped warbler & winter & 1 & & & \\
\hline Setophaga dominica & yellow-throated warbler ${ }^{e}$ & summer & 162 & & & \\
\hline Setophaga discolor & prairie warbler $^{e}$ & summer & 382 & $\mathrm{MC}$ & & $\mathrm{RC}$ \\
\hline Setophaga virens & black-throated green warbler ${ }^{f}$ & summer & 1 & & & \\
\hline Cardellina canadensis & Canada warbler & occasional & 0 & $\mathrm{MC}$ & & \\
\hline Cardellina pusilla & Wilson's warbler & occasional & 0 & & & \\
\hline Icteria virens & yellow-breasted chat ${ }^{e}$ & summer & 989 & & & $\mathrm{RC}$ \\
\hline \multicolumn{7}{|c|}{ Towhees, Sparrows, and Allies } \\
\hline
\end{tabular}




\begin{tabular}{|c|c|c|c|c|c|c|}
\hline \multirow{2}{*}{ Scientific name } & \multirow{2}{*}{ Common name } & \multirow{2}{*}{ Season $^{b}$} & \multirow{2}{*}{$\begin{array}{c}\text { PIF } \\
\text { Obs }^{c}\end{array}$} & \multicolumn{3}{|c|}{ Status $^{d}$} \\
\hline & & & & Federal & State & PIF \\
\hline Pipilo erythrophthalmus & eastern towhee $^{e}$ & year-round & 652 & & & $\mathrm{RC}$ \\
\hline Peucaea aestivalis & Bachman's sparrow $^{e}$ & occasional $^{i}$ & 0 & $\mathrm{MC}$ & $E$ & $\mathrm{RC}$ \\
\hline Spizella arborea & American tree sparrow & historic & 0 & & & \\
\hline Spizella passerina & chipping sparrow $^{e}$ & year-round & 60 & & & \\
\hline Spizella pusilla & field sparrow $^{e}$ & year-round & 494 & & & $\mathrm{RC}$ \\
\hline Pooecetes gramineus & vesper sparrow & migrant & 0 & & NM & \\
\hline Passerculus sandwichensis & savannah sparrow & winter & 0 & & & \\
\hline Ammodramus savannarum & grasshopper sparrow $^{e}$ & summer & 9 & & & $\mathrm{RC}$ \\
\hline Ammodramus henslowii & Henslow's sparrow & occasional & 0 & $\mathrm{MC}$ & NM & $\mathrm{RC}$ \\
\hline Passerella iliaca & fox sparrow & winter & 0 & & & \\
\hline Melospiza lincolnii & Lincoln’s sparrow & occasional & 0 & & & \\
\hline Melospiza melodia & song sparrow $^{e}$ & year-round & 105 & & & \\
\hline Melospiza georgiana & swamp sparrow & winter & 0 & & & \\
\hline Zonotrichia albicollis & white-throated sparrow & winter & 0 & & & \\
\hline Zonotrichia leucophrys & white-crowned sparrow & winter & 0 & & & \\
\hline Junco hyemalis & dark-eyed junco & winter & 0 & & & \\
\hline \multicolumn{7}{|c|}{ Tanagers } \\
\hline Piranga rubra & summer tanager $^{e}$ & summer & 285 & & & $\mathrm{RC}$ \\
\hline Piranga olivacea & scarlet tanager $^{e}$ & summer & 1060 & & & \\
\hline \multicolumn{7}{|c|}{ Cardinals, Grosbeaks, and Allies } \\
\hline Pheucticus ludovicianus & rose-breasted grosbeak & migrant & 1 & & & \\
\hline Passerina caerulea & blue grosbeak $^{e}$ & summer & 56 & & & \\
\hline Passerina cyanea & indigo bunting $^{e}$ & summer & 1376 & & & \\
\hline Cardinalis cardinalis & northern cardinal $^{e}$ & year-round & 1557 & & & \\
\hline Spiza americana & dickcissel & occasional & 0 & $\mathrm{MC}$ & & \\
\hline \multicolumn{7}{|c|}{ Blackbirds and Allies } \\
\hline Dolichonyx oryzivorus & bobolink & occasional & 0 & & & \\
\hline Agelaius phoeniceus & red-winged blackbird $^{e}$ & year-round & 163 & & & \\
\hline Sturnella magna & eastern meadowlark ${ }^{e}$ & year-round & 75 & & & $\mathrm{RC}$ \\
\hline Euphagus carolinus & rusty blackbird & occasional & 0 & $\mathrm{MC}$ & & \\
\hline
\end{tabular}




\begin{tabular}{|c|c|c|c|c|c|c|}
\hline \multirow{2}{*}{ Scientific name } & \multirow{2}{*}{ Common name } & \multirow{2}{*}{ Season $^{b}$} & \multirow{2}{*}{$\begin{array}{l}\text { PIF } \\
\text { Obs }^{c}\end{array}$} & \multicolumn{3}{|c|}{ Status $^{d}$} \\
\hline & & & & Federal & State & $\overline{\text { PIF }}$ \\
\hline Quiscalus quiscula & common grackle $^{e}$ & year-round & 184 & & & \\
\hline Molothrus ater & brown-headed cowbird $^{e}$ & year-round & 500 & & & \\
\hline Icterus spurius & orchard oriole $^{e}$ & summer & 60 & & & \\
\hline Icterus galbula & Baltimore oriole $^{e}$ & summer & 2 & & & \\
\hline \multicolumn{7}{|c|}{ Finches } \\
\hline Haemorphous mexicanus & house finch $^{e}$ & year-round & 35 & & & \\
\hline Haemorphous purpureus & purple finch & winter & 0 & & & \\
\hline Loxia curvirostra & red crossbill & occasional & 0 & $\mathrm{MC}$ & & $\mathrm{RC}$ \\
\hline Spinus pinus & pine siskin & winter & 0 & & & \\
\hline Spinus tristis & American goldfinch $^{e}$ & year-round & 703 & & & \\
\hline Coccothraustes vespertinus & evening grosbeak & occasional & 0 & & & \\
\hline \multicolumn{7}{|c|}{ Old World Sparrows } \\
\hline Passer domesticus & house sparrow $^{e}$ & year-round & 1 & & & \\
\hline
\end{tabular}

${ }^{a}$ Land, surface waters, and boundary waters of the Oak Ridge Reservation; all records from 1950 to 2014.

${ }^{b}$ Occasional—very seldom found, most are migrants and some are out-of-range; historic—no records after 1953 (except Bewick's wren—no records after 1957);

migrant—found primarily during spring or fall migration; summer-found primarily in summer (including migration); winter—found primarily in winter (including migration); year-round-may be found year-round.

${ }^{c}$ PIF Obs = Number of observations during Partners in Flight breeding bird surveys, 1995-2013.

${ }^{d} \mathrm{E}$ = endangered; $\mathrm{T}$ = threatened; $\mathrm{MC}$ = species of management concern; $\mathrm{NM}$ = in need of management; $\mathrm{RC}$ = considered of regional concern by Partners in Flight in the Appalachian Mountain Region.

${ }^{e}$ Breeding bird, past or present, on the Oak Ridge Reservation.

${ }^{f}$ Potential breeding bird, past or present, on the Oak Ridge Reservation.

${ }^{9}$ The bald eagle was federally delisted effective August 8, 2007.

${ }^{h}$ The peregrine falcon was federally delisted effective August 25, 1999.

${ }^{i}$ No records of Bachman's sparrow after 1982 
APPENDIX B. PARTNERS IN FLIGHT BIRD OBSERVATION TRENDS FOR SPECIES ON THE OAK RIDGE RESERVATION OF REGIONAL CONCERN 



\section{APPENDIX B. PARTNERS IN FLIGHT BIRD OBSERVATION TRENDS FOR SPECIES ON THE OAK RIDGE RESERVATION OF REGIONAL CONCERN}

Note: Linear trends are not related to statistical analysis and only display slope of the line.

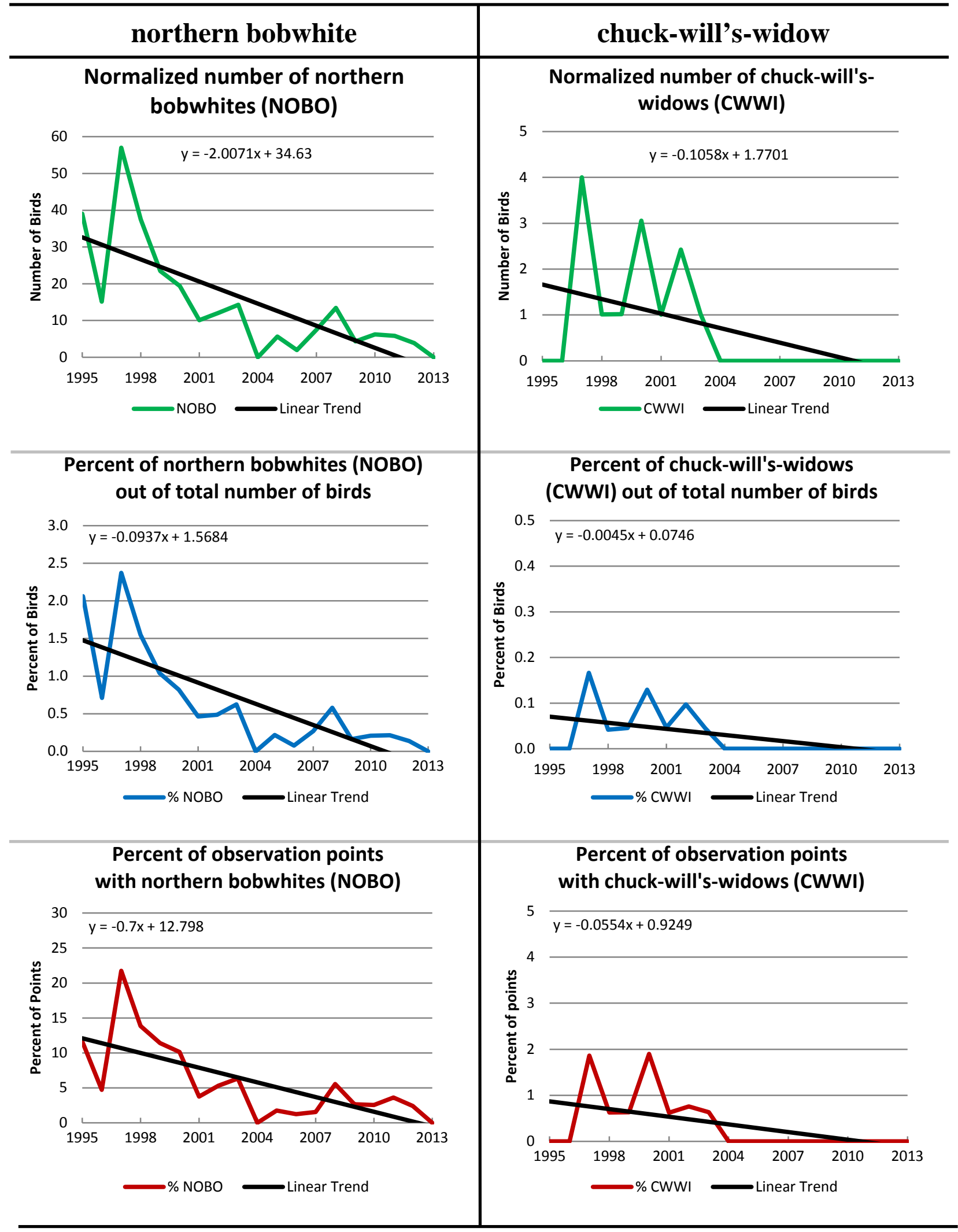




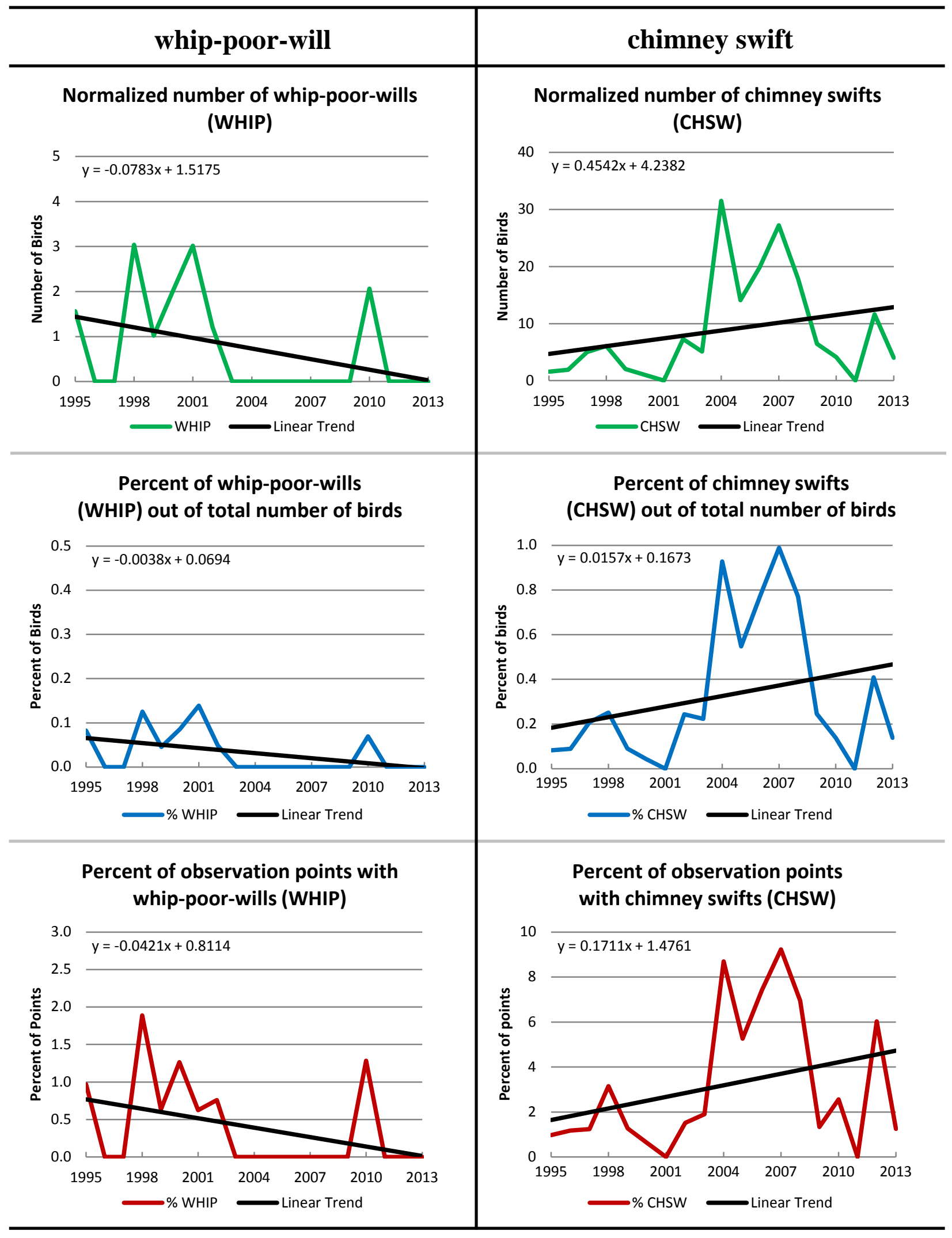




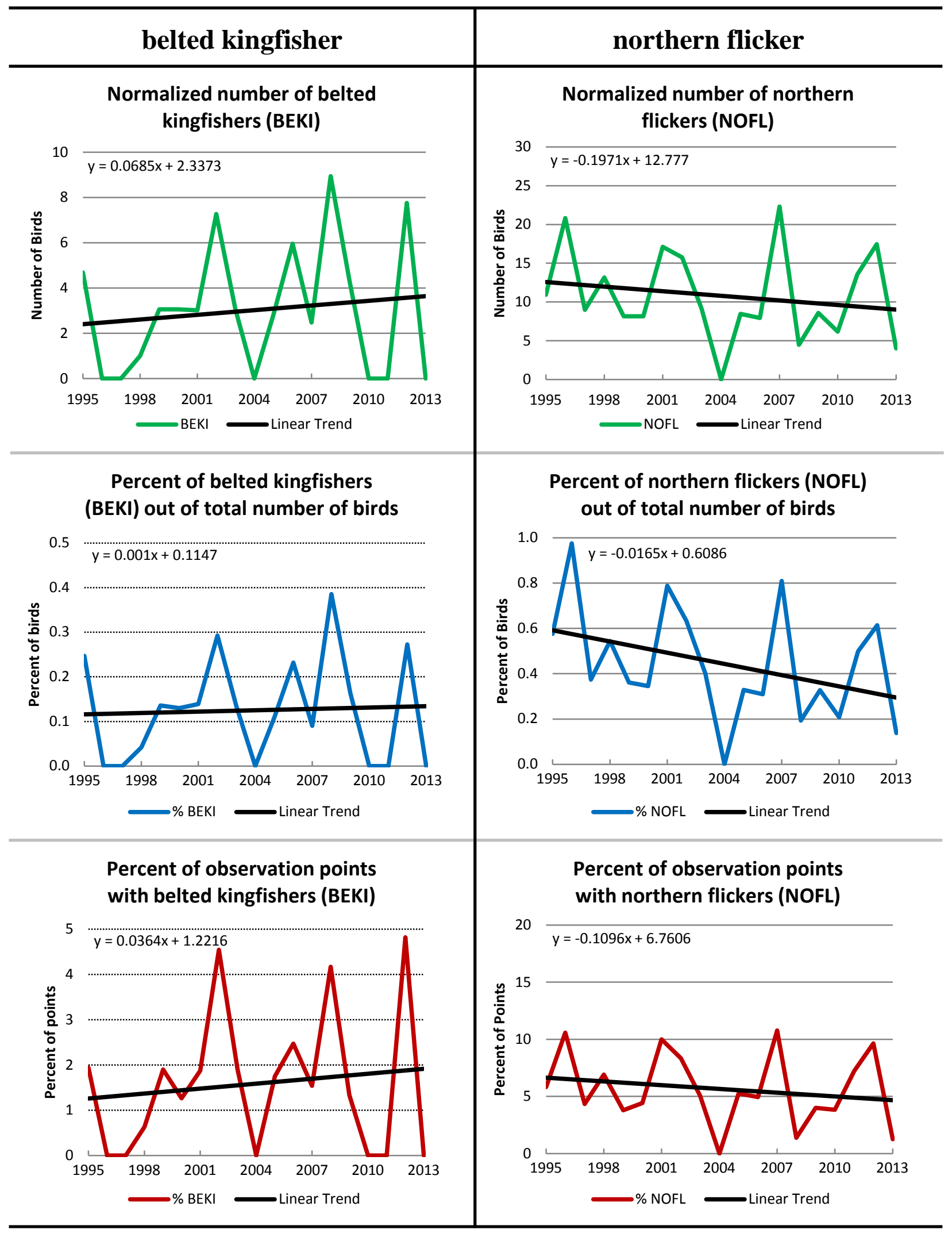




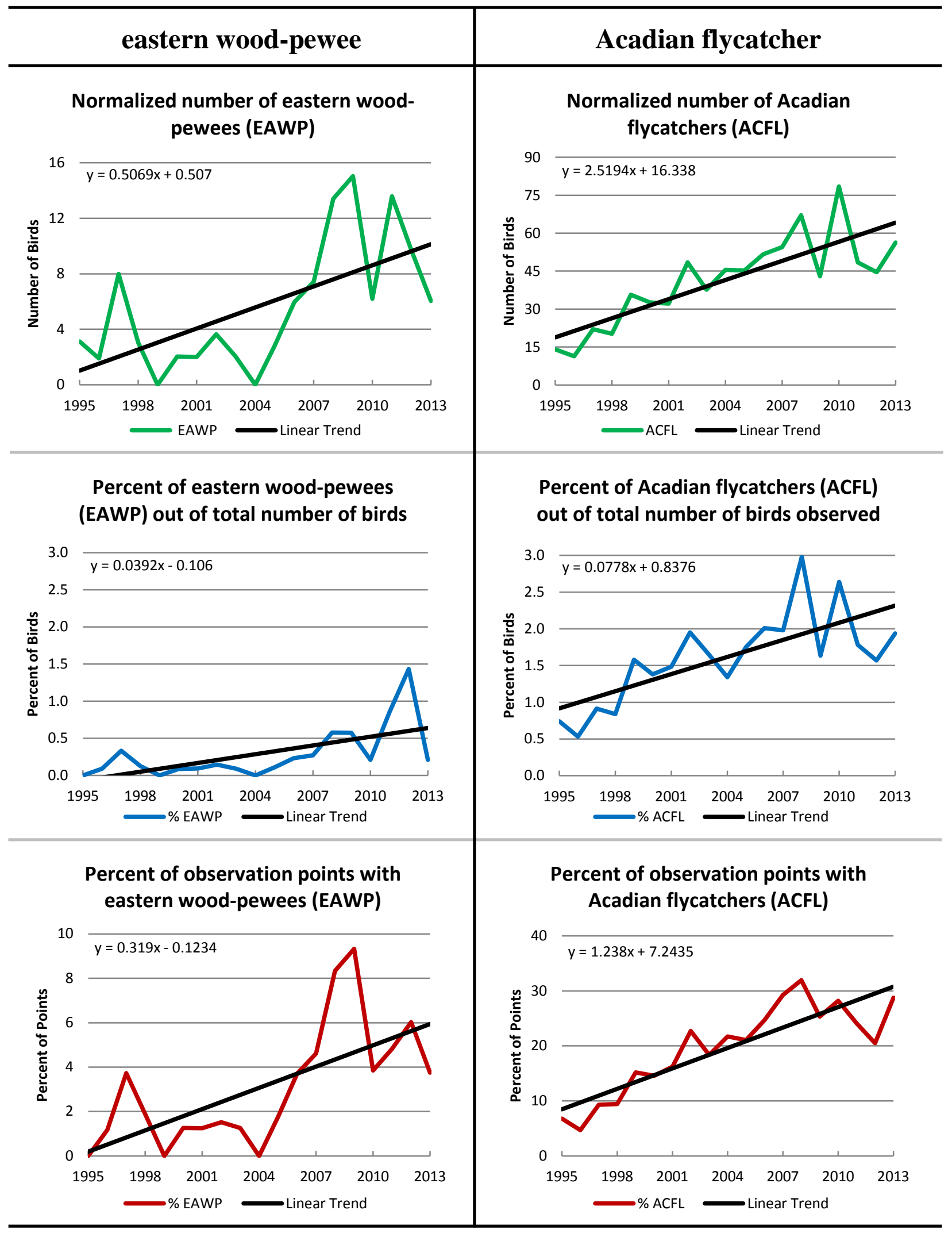




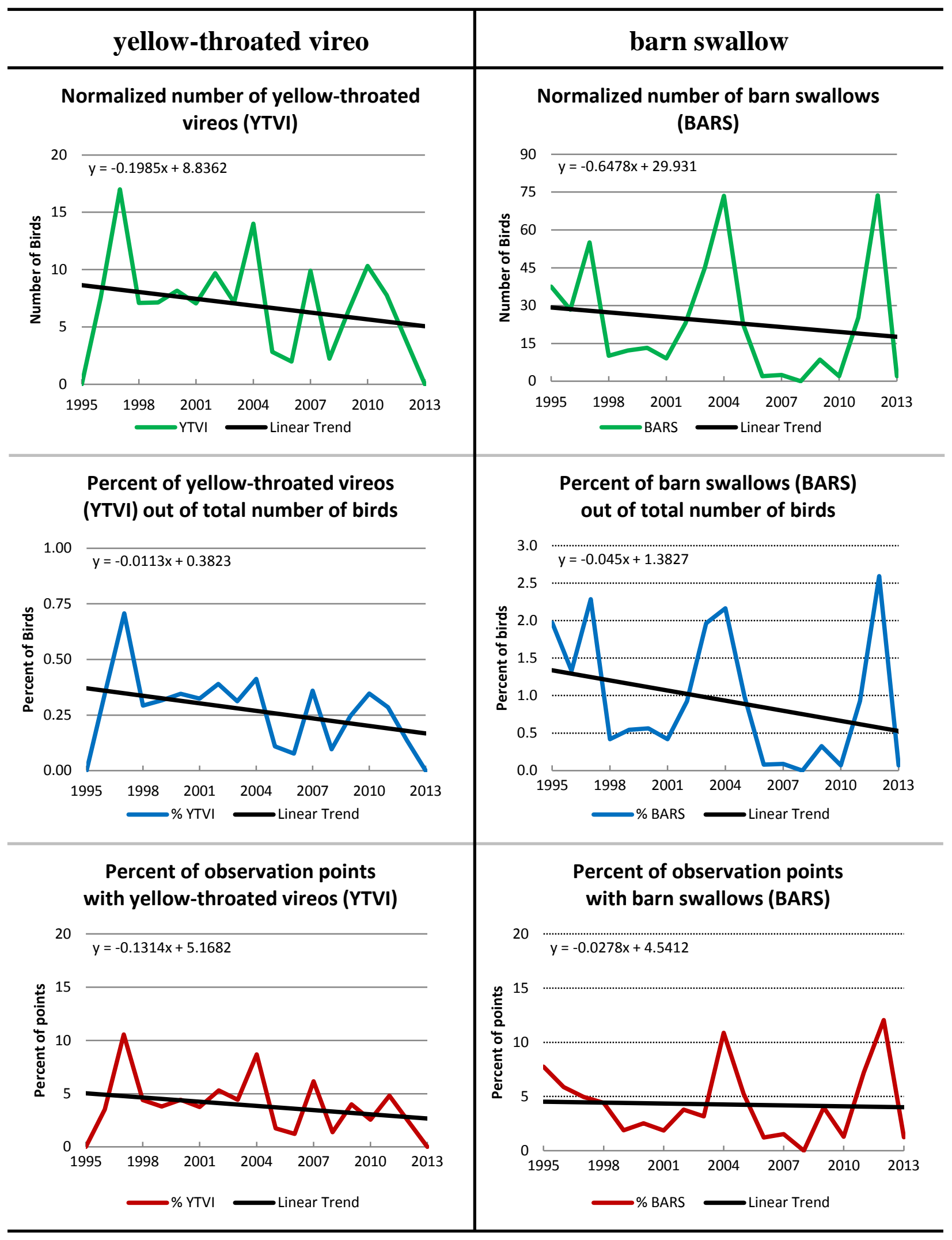




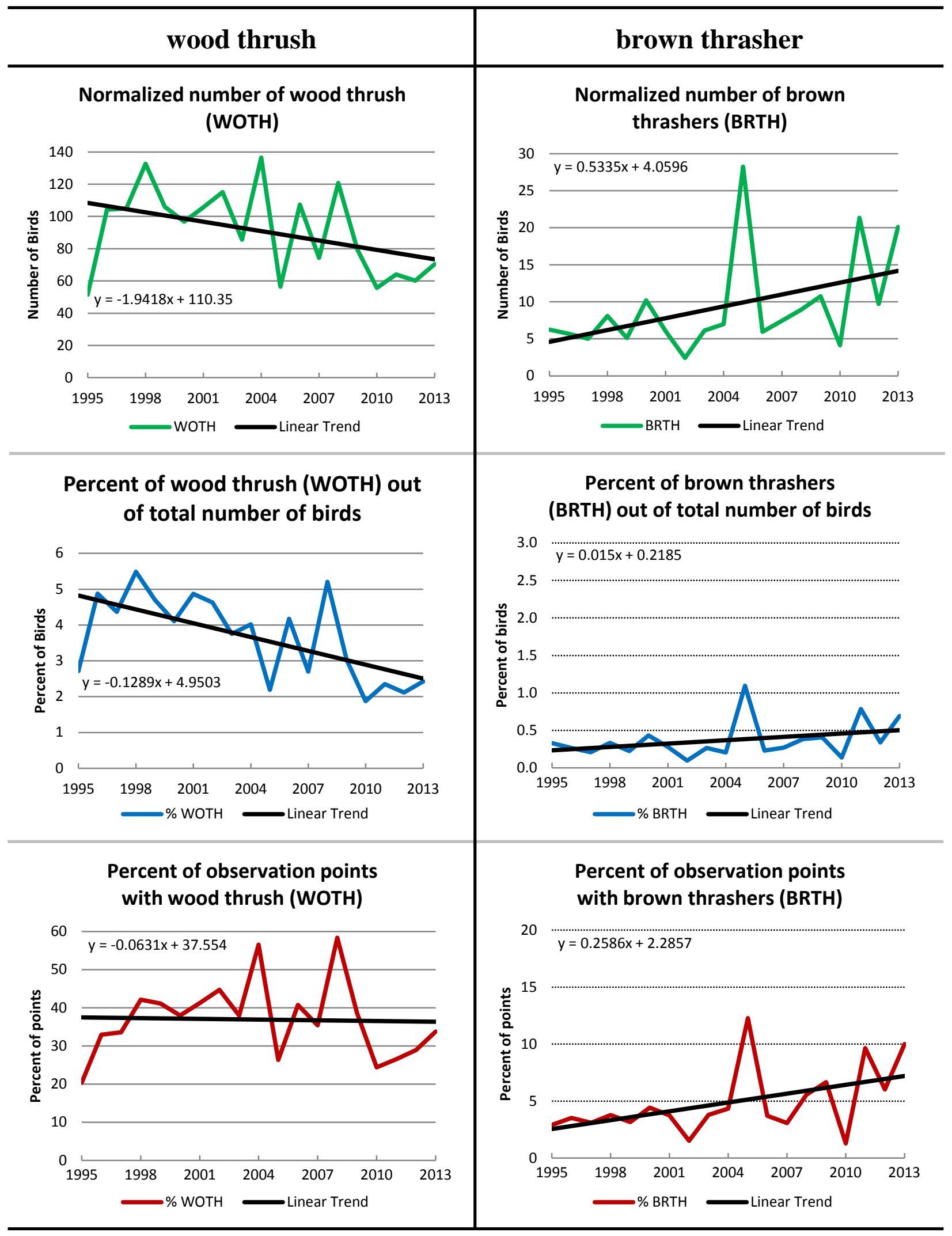




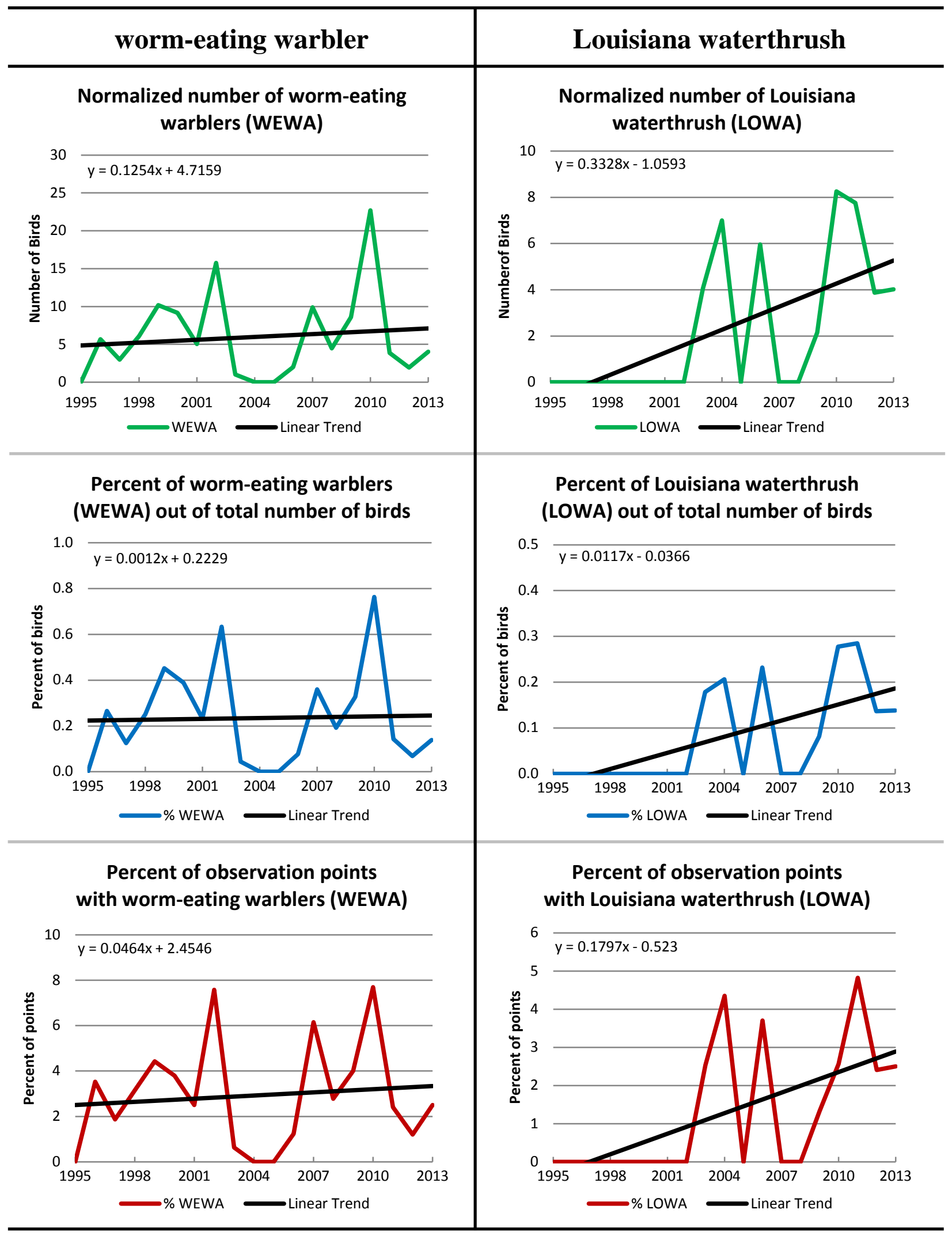




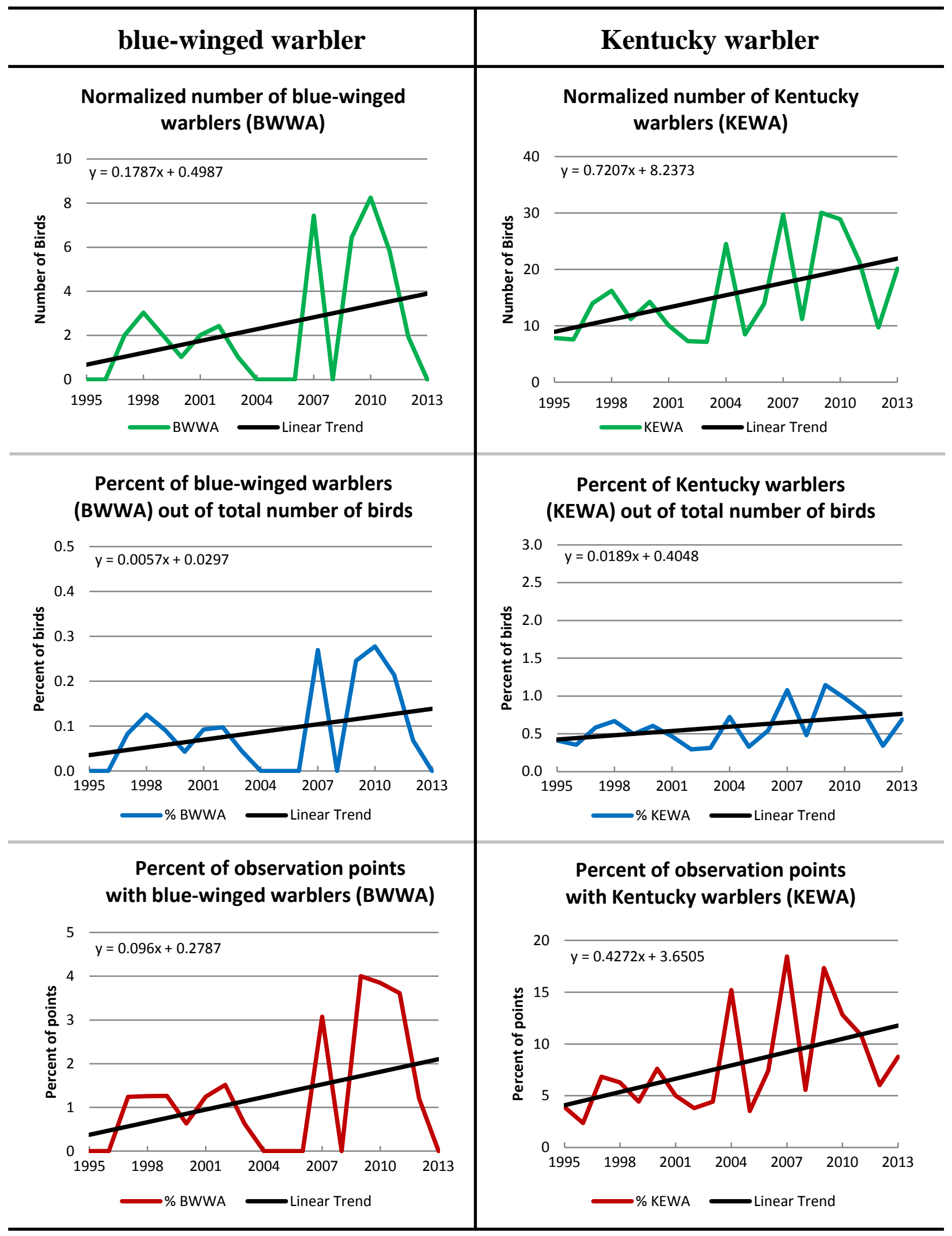




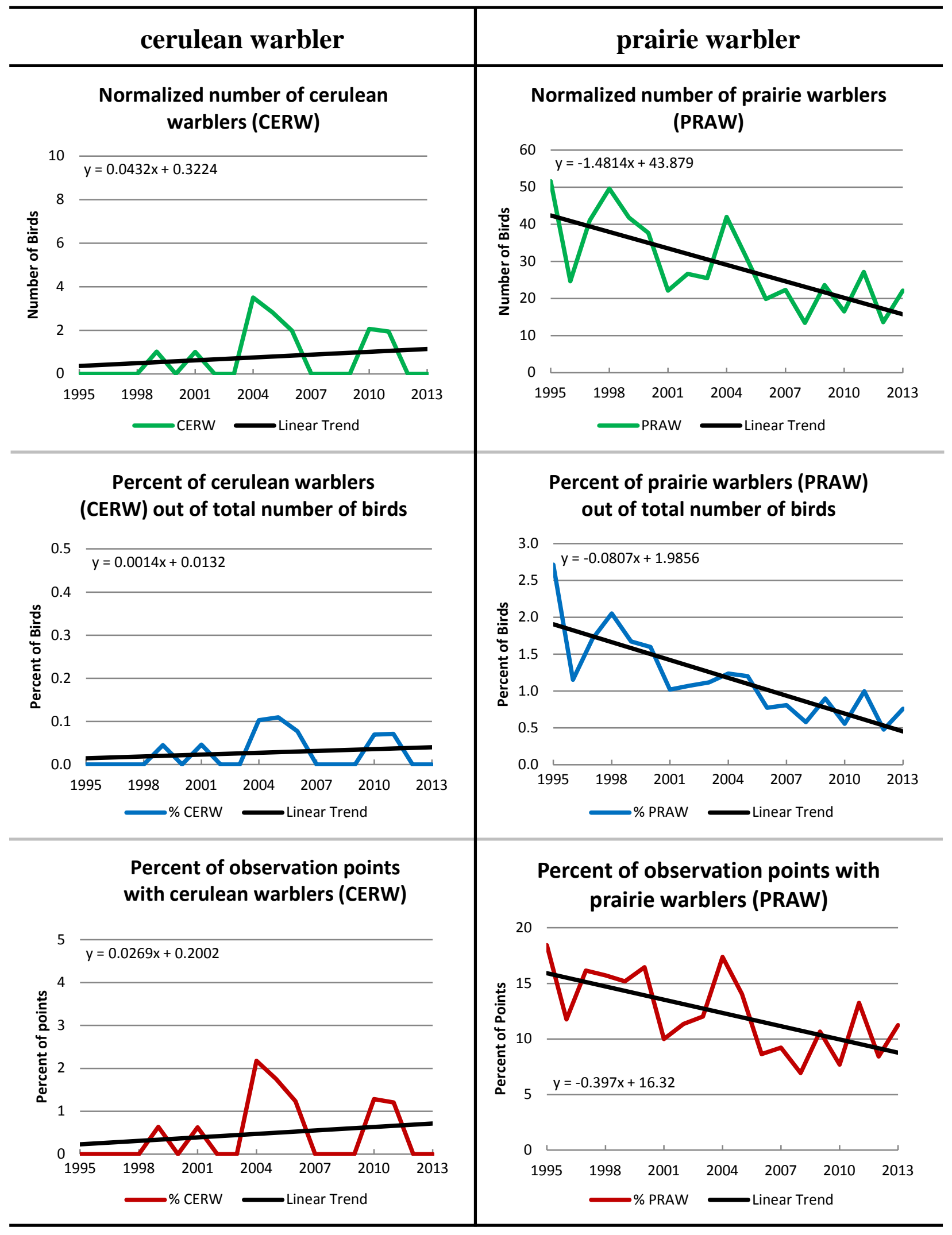




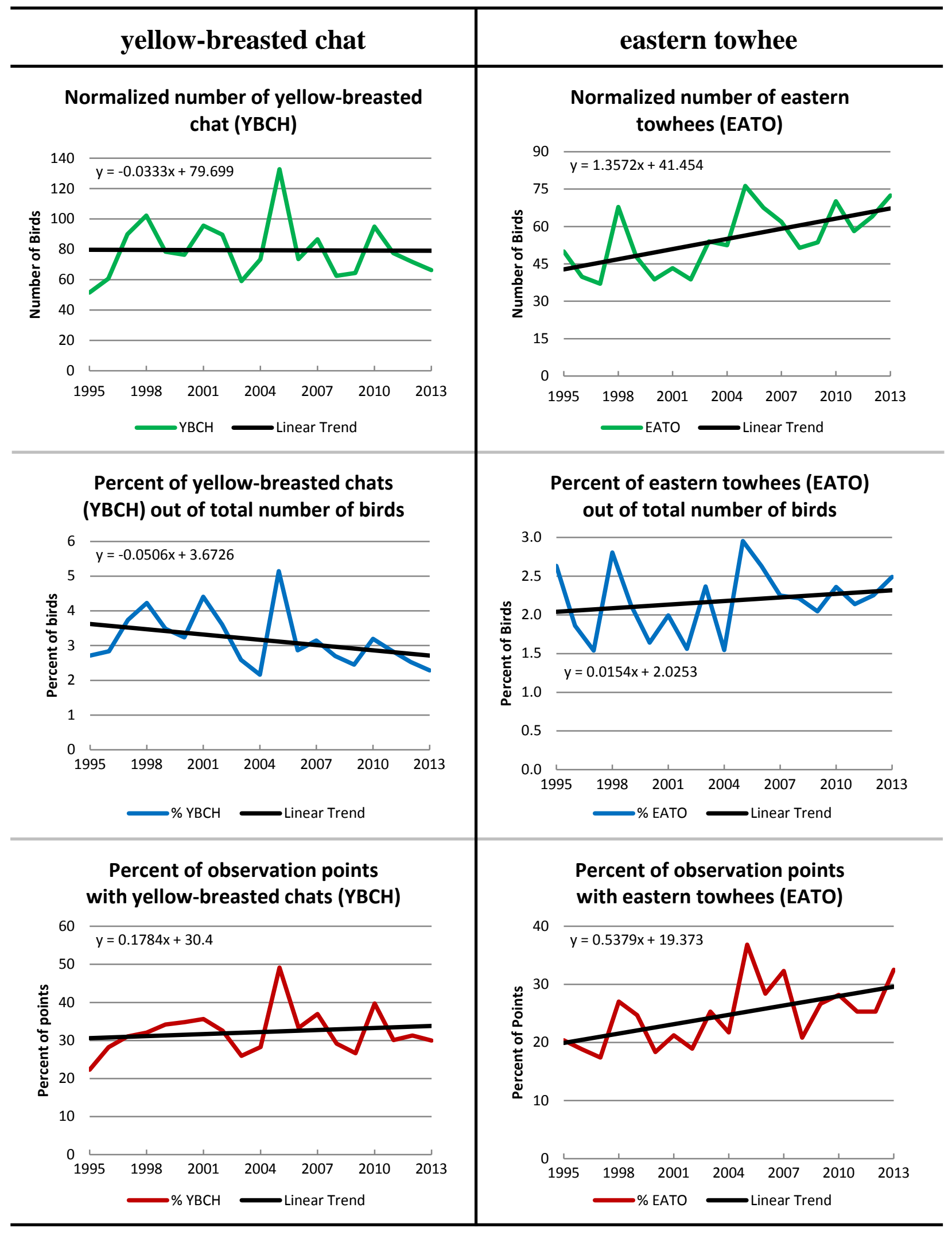




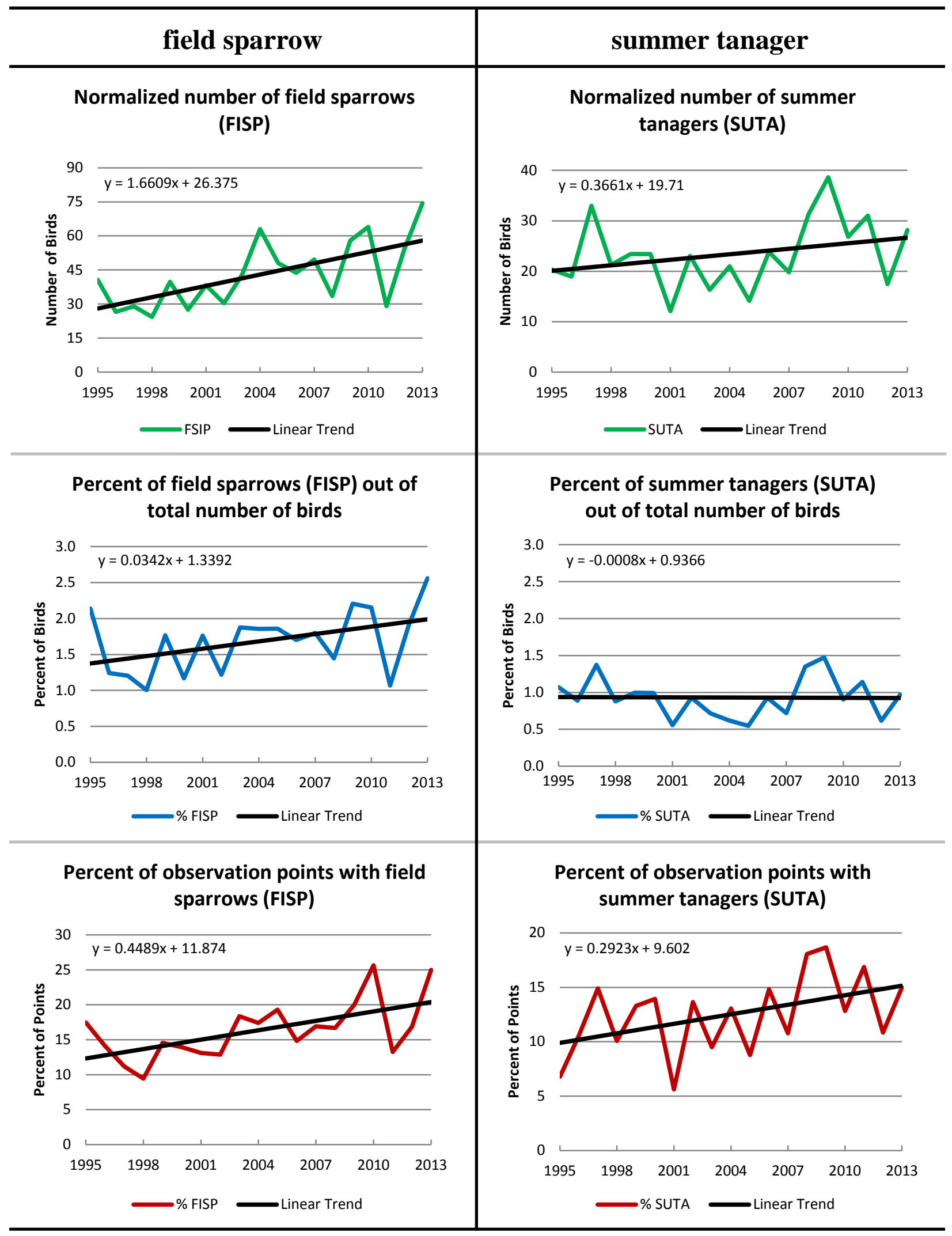




\section{eastern meadowlark}
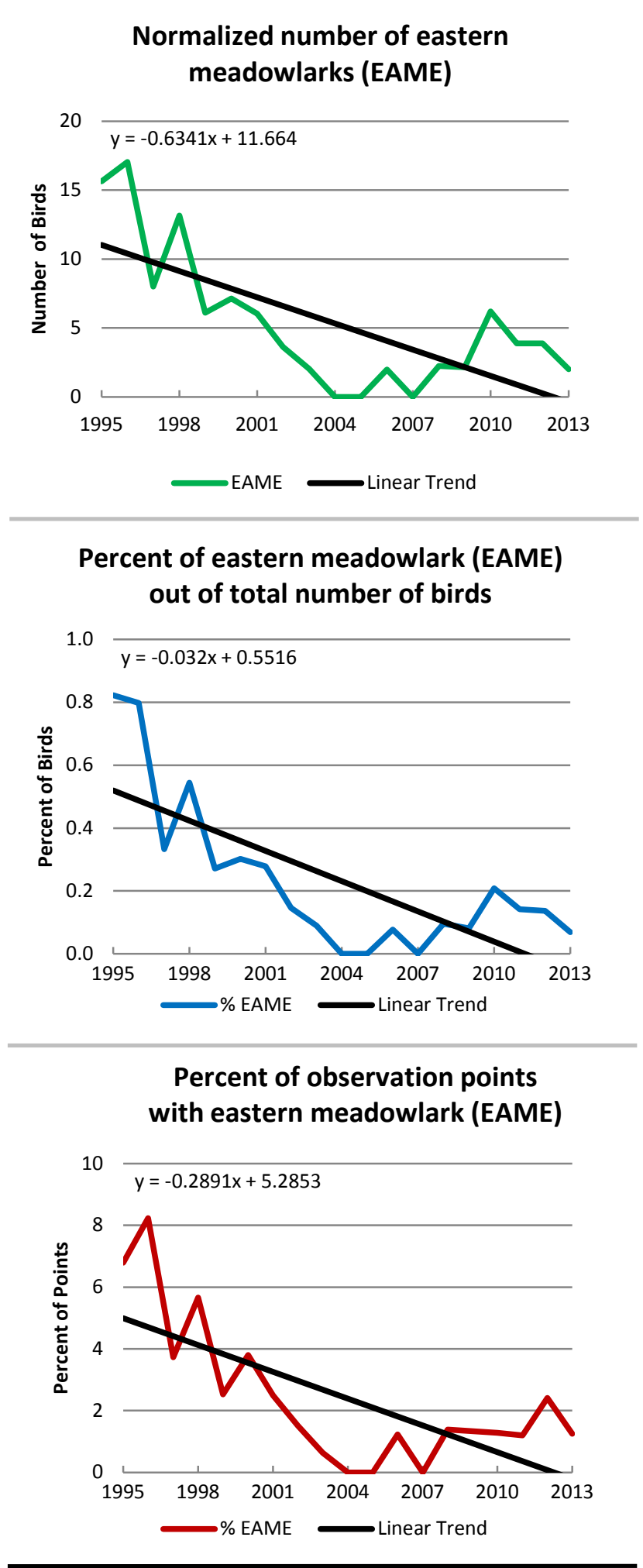
APPENDIX C. PARTNERS IN FLIGHT BIRD OBSERVATION TRENDS FOR SPECIES OF LOCAL INTEREST ON THE OAK RIDGE RESERVATION 



\section{APPENDIX C. PARTNERS IN FLIGHT BIRD OBSERVATION TRENDS FOR SPECIES OF LOCAL INTEREST ON THE OAK RIDGE RESERVATION}

Note: Linear trends are not related to statistical analysis and only display slope of the line.

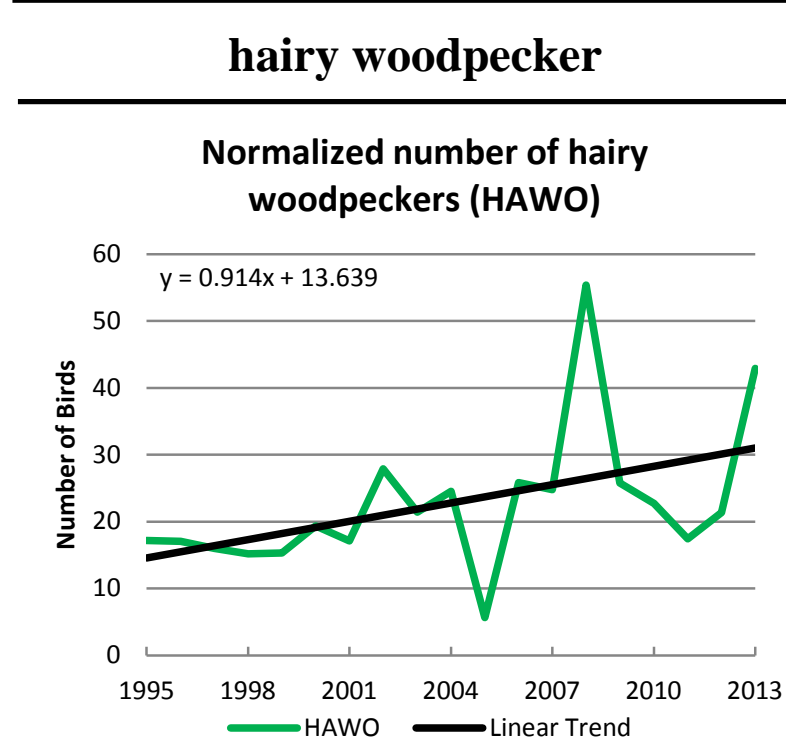

Percent of hairy woodpeckers (HAWO) out of total number of birds

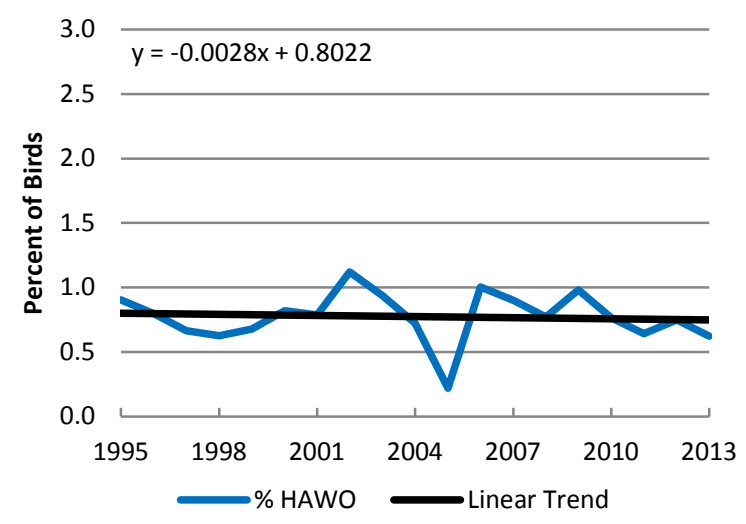

Percent of observation points with hairy woodpeckers (HAWO)

$20 \quad y=0.1691 x+9.3711$
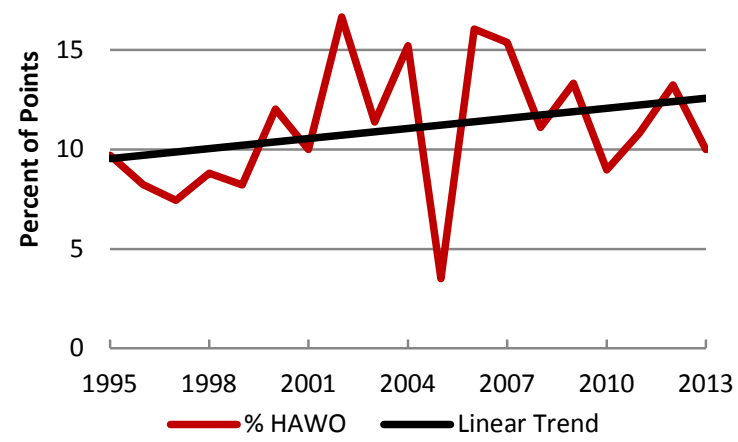

pileated woodpecker

Normalized number of pileated woodpecker (PIWO)

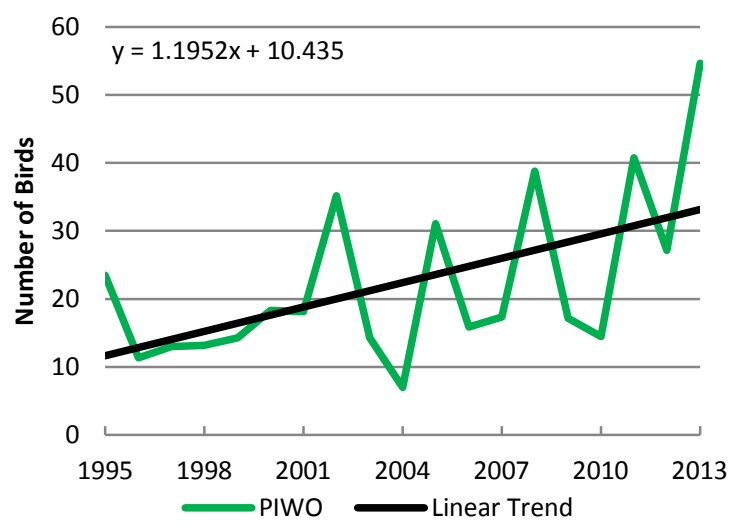

Percent of pileated woodpeckers (PIWO) out of total number of birds

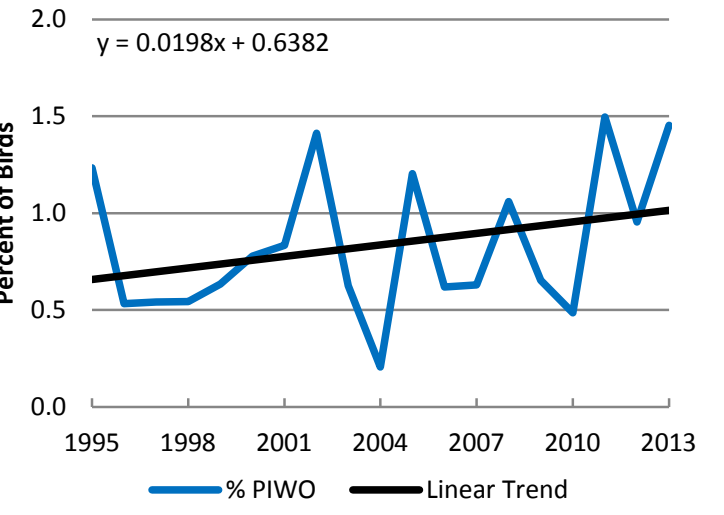

Percent of observation points with pileated woodpeckers (PIWO)

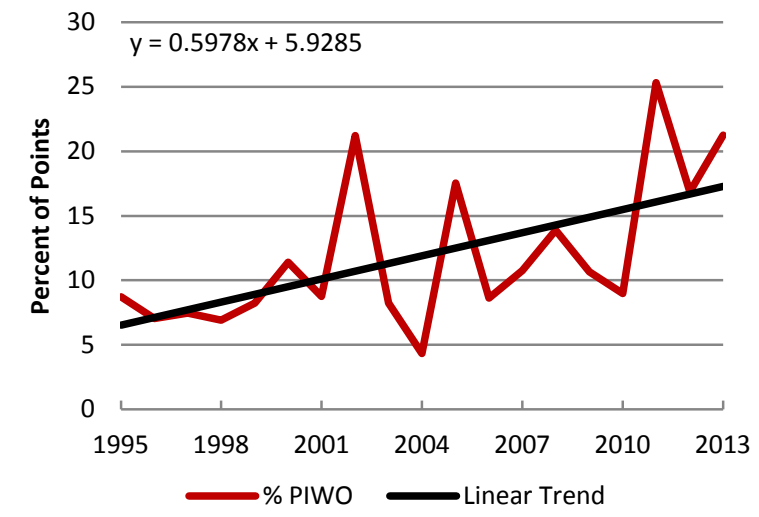




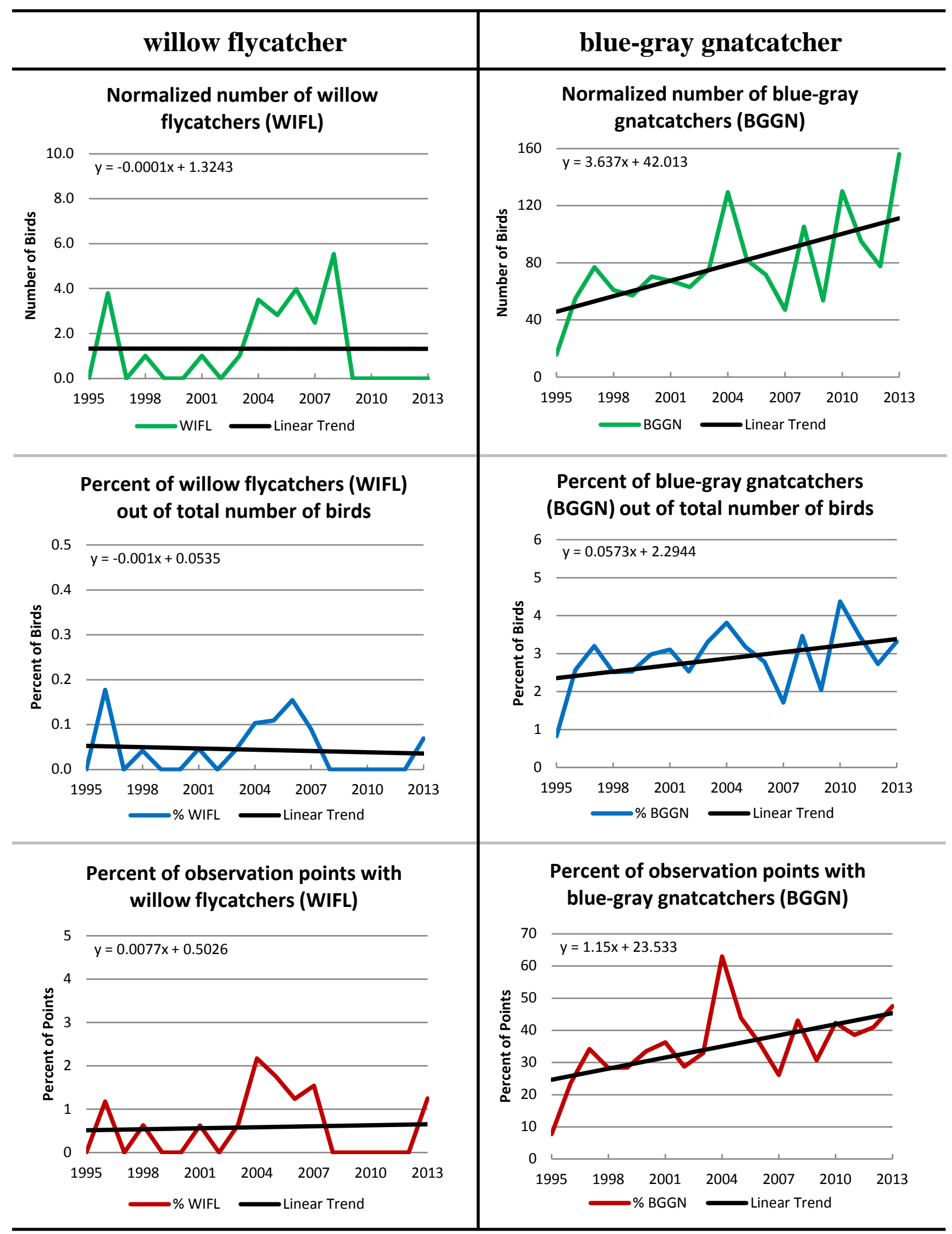




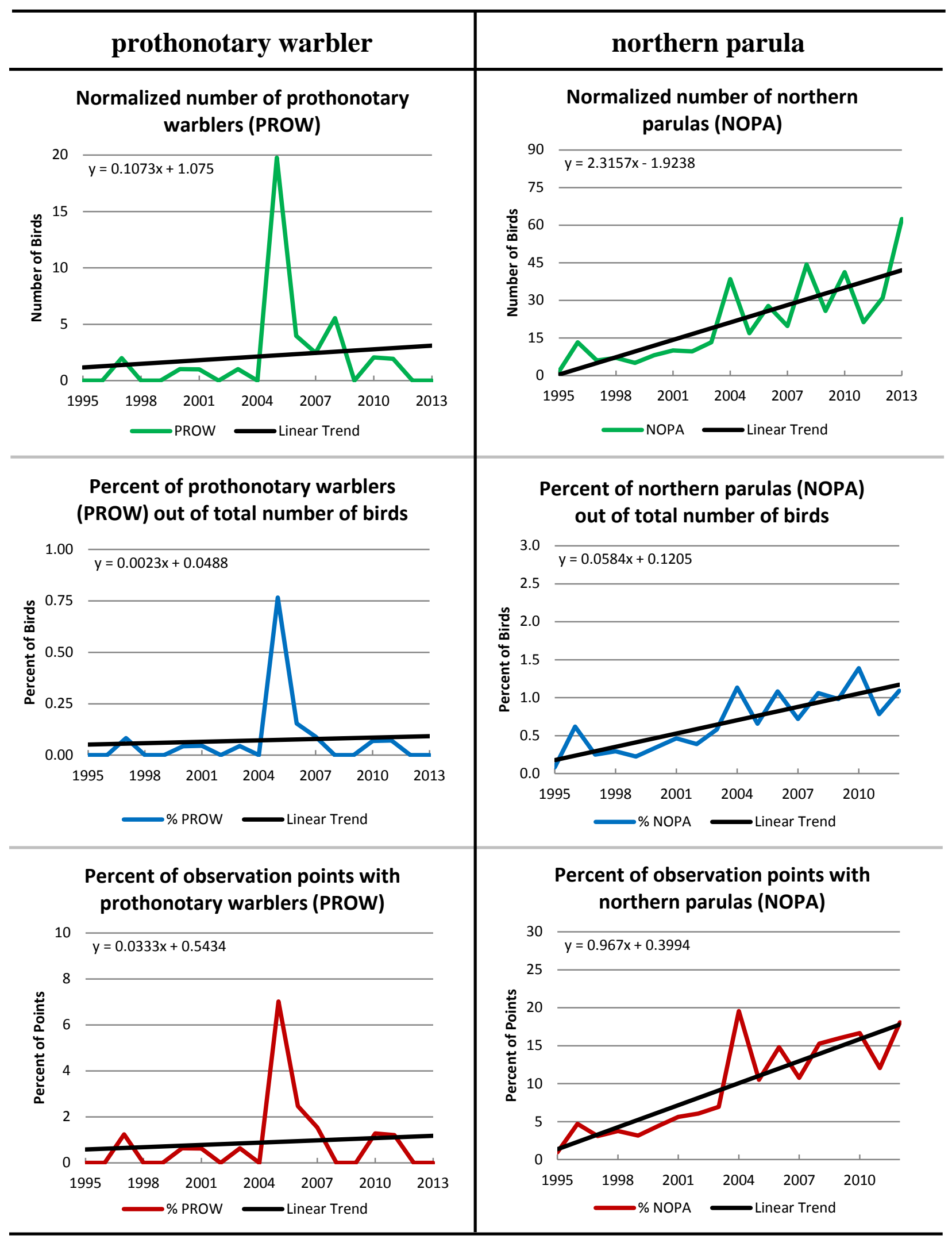




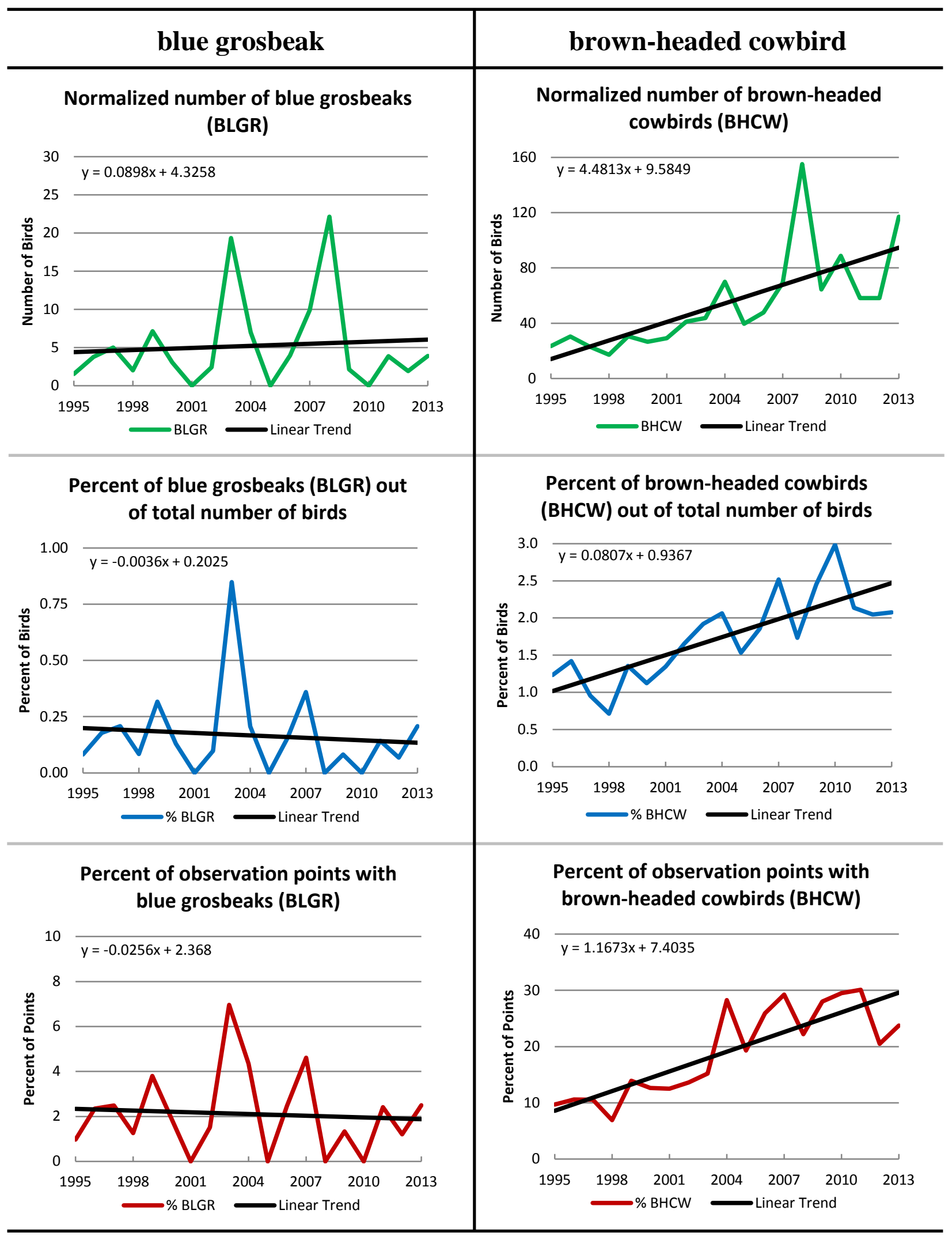



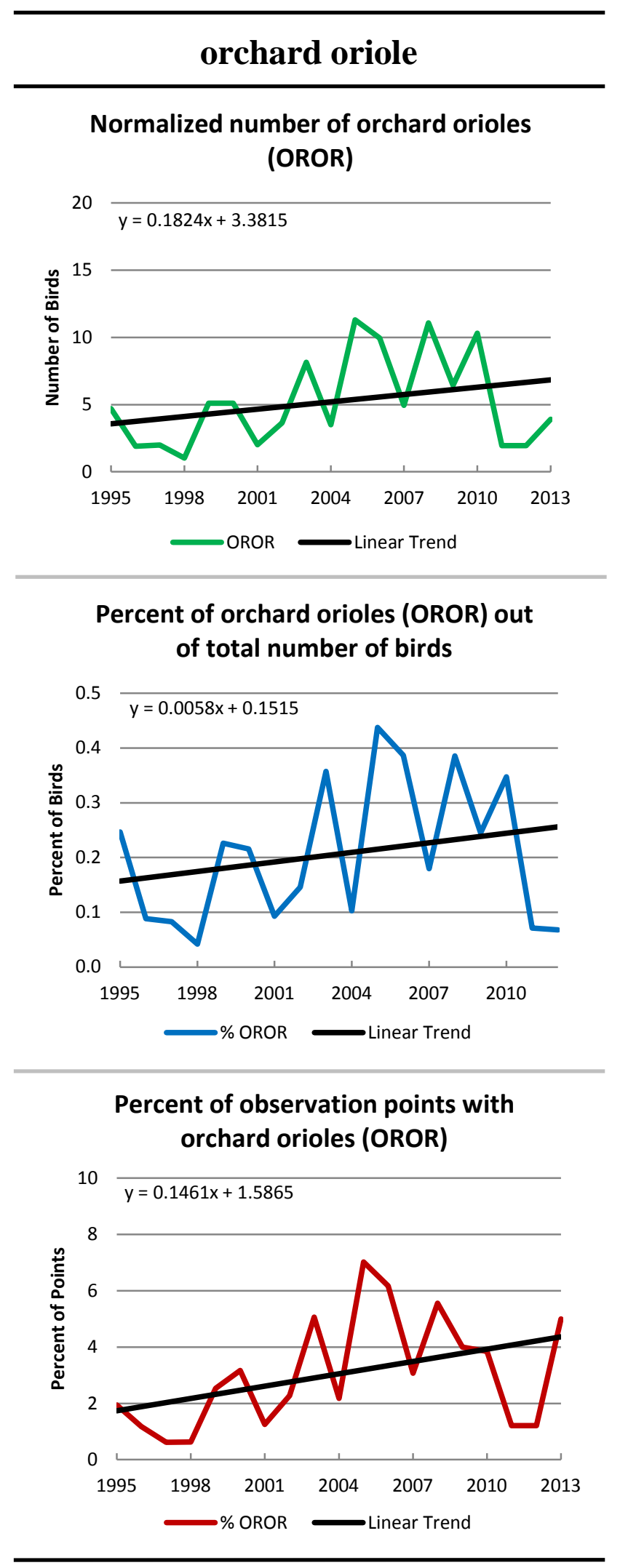

APPENDIX D. AERIAL PHOTOS OF THE OAK RIDGE RESERVATION 

APPENDIX D. AERIAL PHOTOS OF THE OAK RIDGE RESERVATION

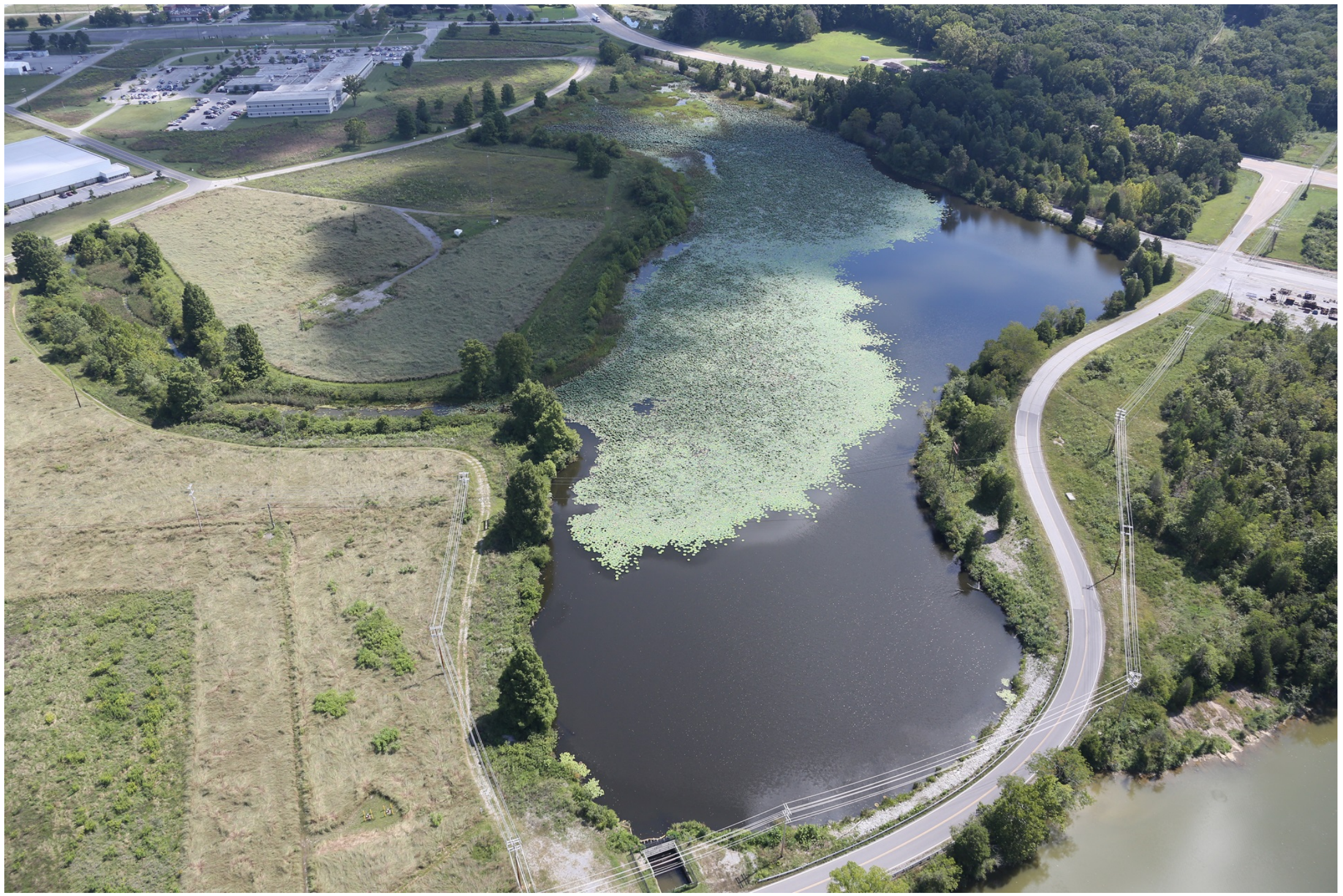

K1007-P1 Pond showing extensive growth of American lotus and other aquatic vegetation (September 2013). (Photo: Jason Richards) 


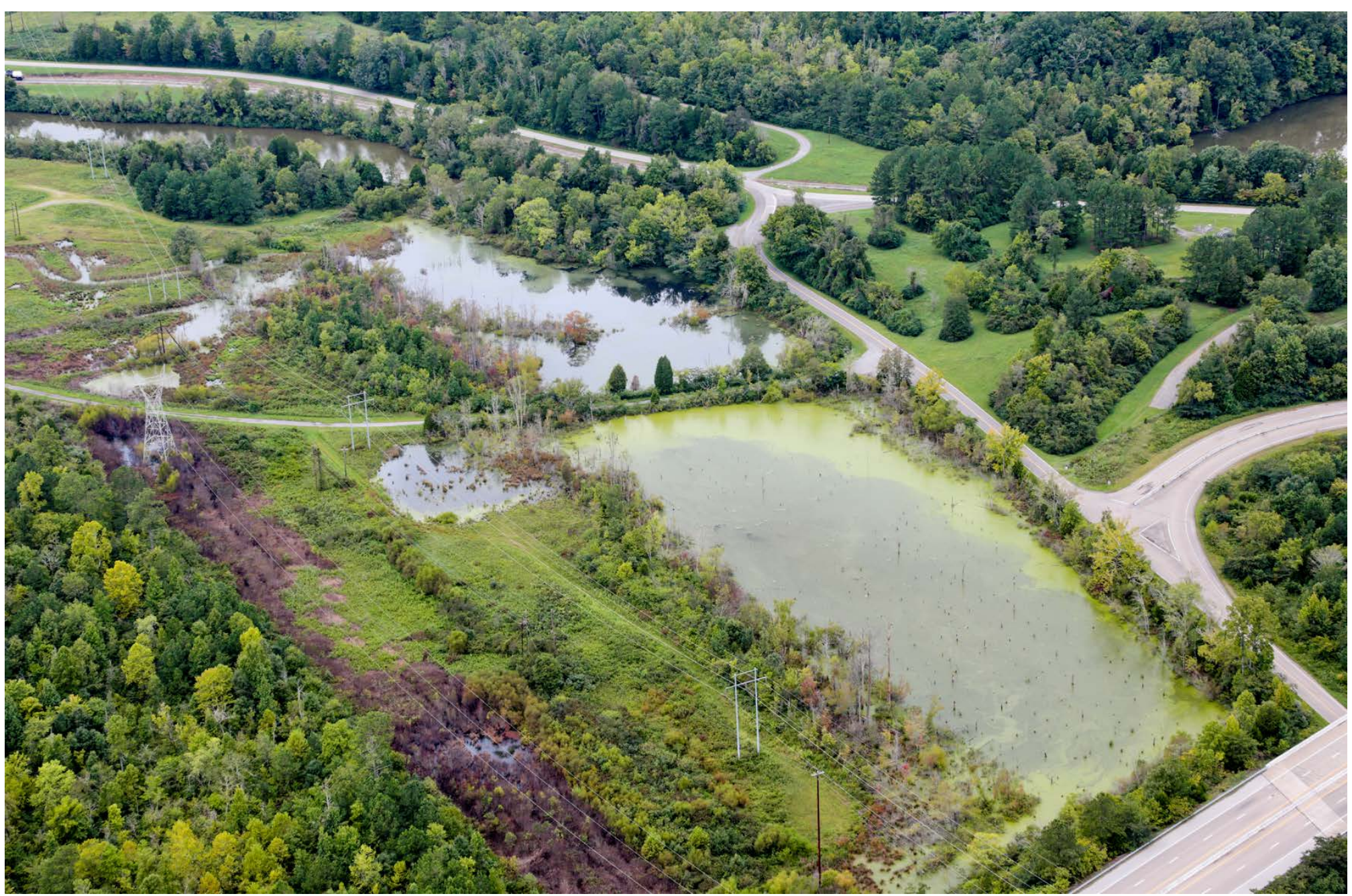

East Tennessee Technology Park beaver pond complex, showing wetlands and impoundment with standing dead snags (September 2014). (Photo: Jason Richards) 


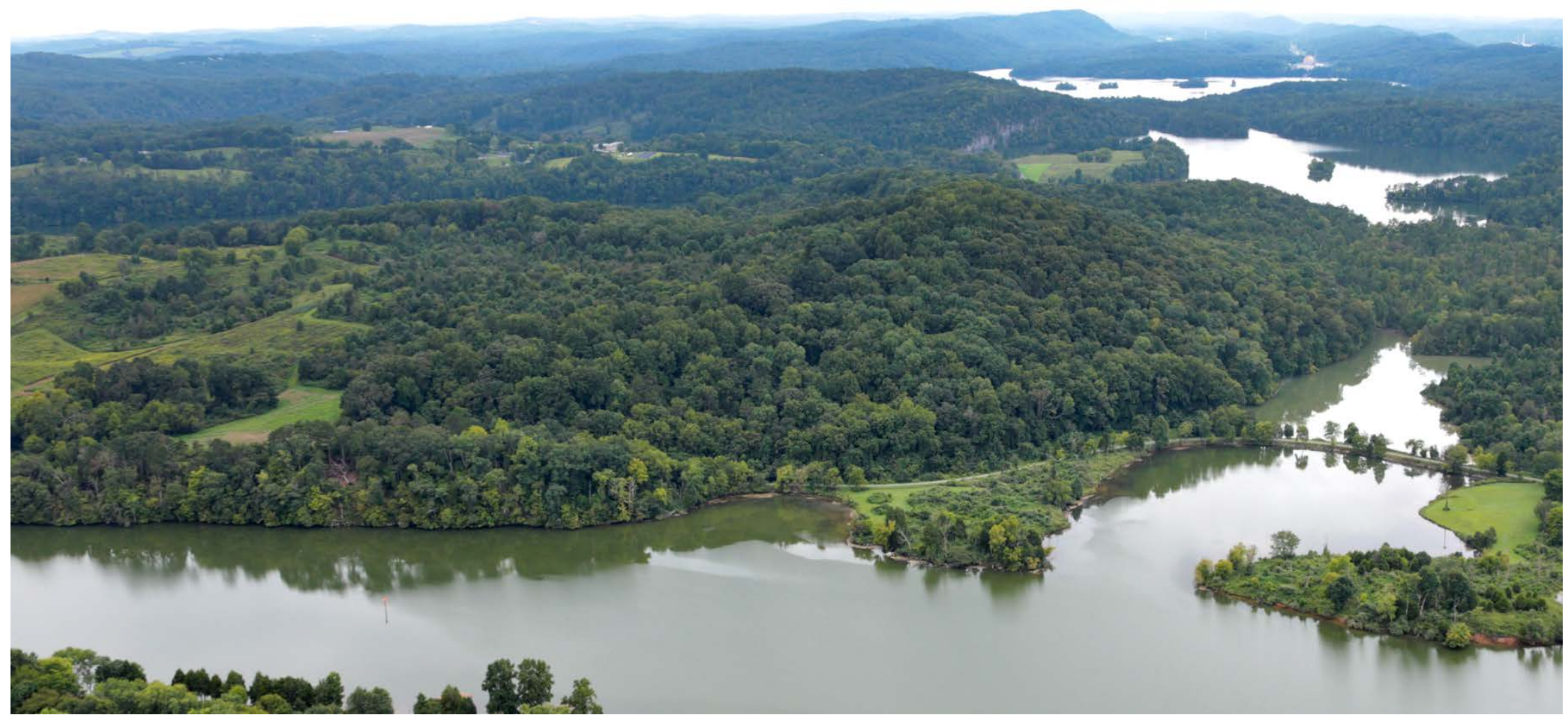

A view of the north end of Freels Bend, showing Melton Hill Reservoir (foreground and in the distance on the right), the Freels Bend land bridge (lower right), and early succession and field habitat (left side), which is characteristic of much of Freels Bend (September 2014). (Photo: Jason Richards) 


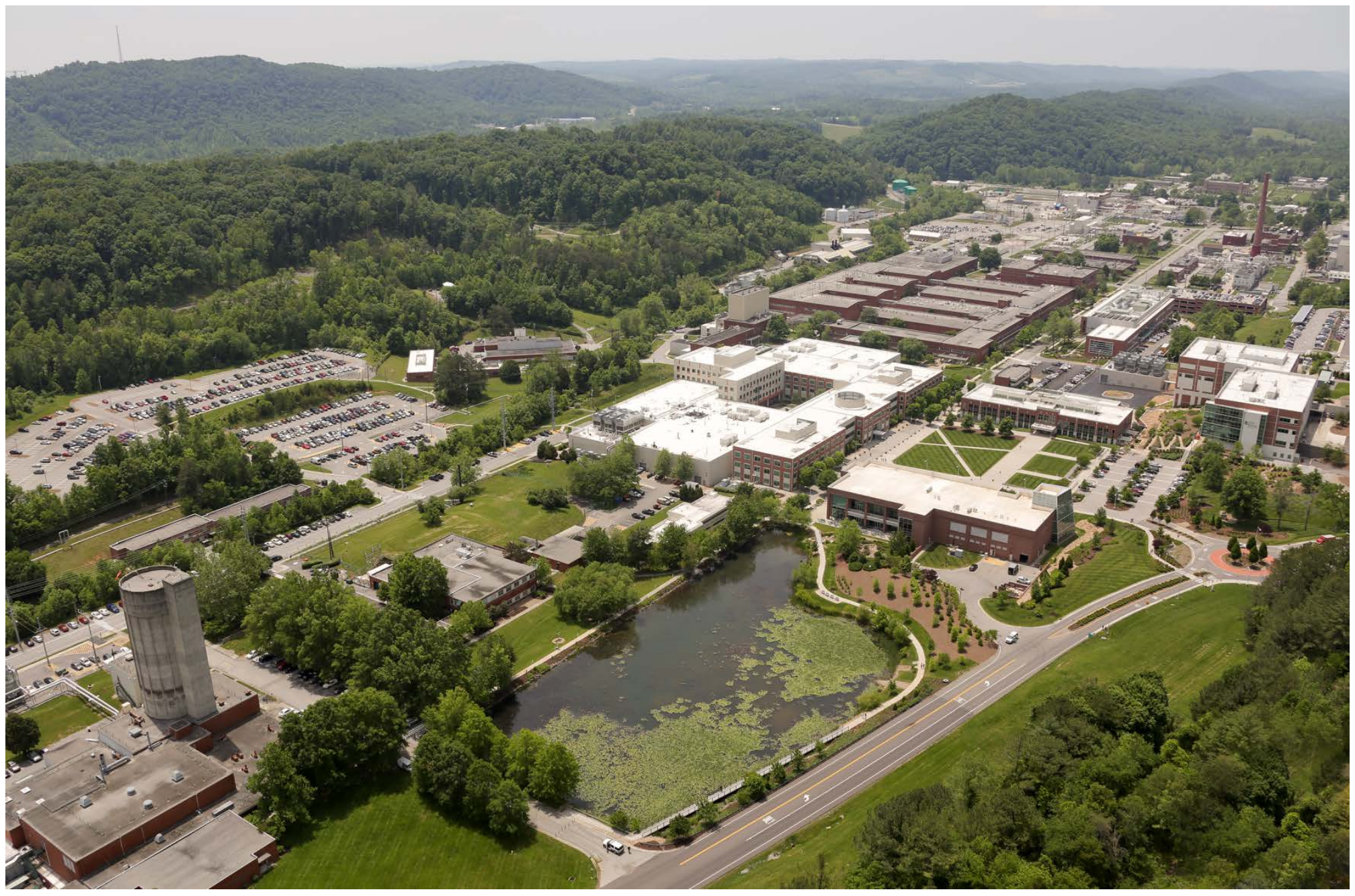

A view of Oak Ridge National Laboratory with the Swan Pond in the foreground, Haw Ridge in the immediate background, and Copper Ridge in the upper left (May 2014). (Photo: Jason Richards) 
APPENDIX E. HABITAT TYPES ON THE OAK RIDGE RESERVATION 

APPENDIX E. HABITAT TYPES ON THE OAK RIDGE RESERVATION

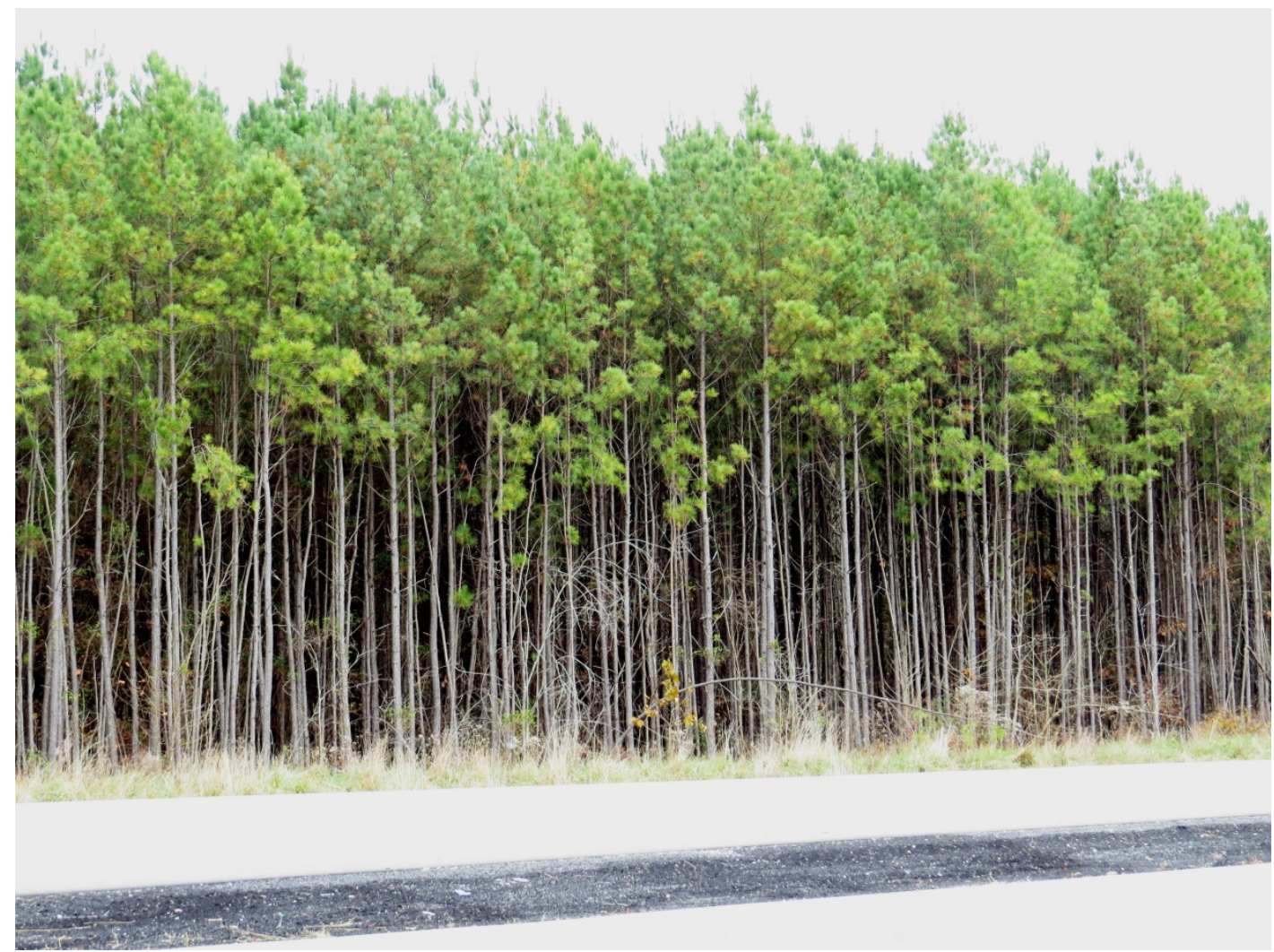

Loblolly Pine Stand, unmanaged (November 2013). (Photo: Kelly Roy)

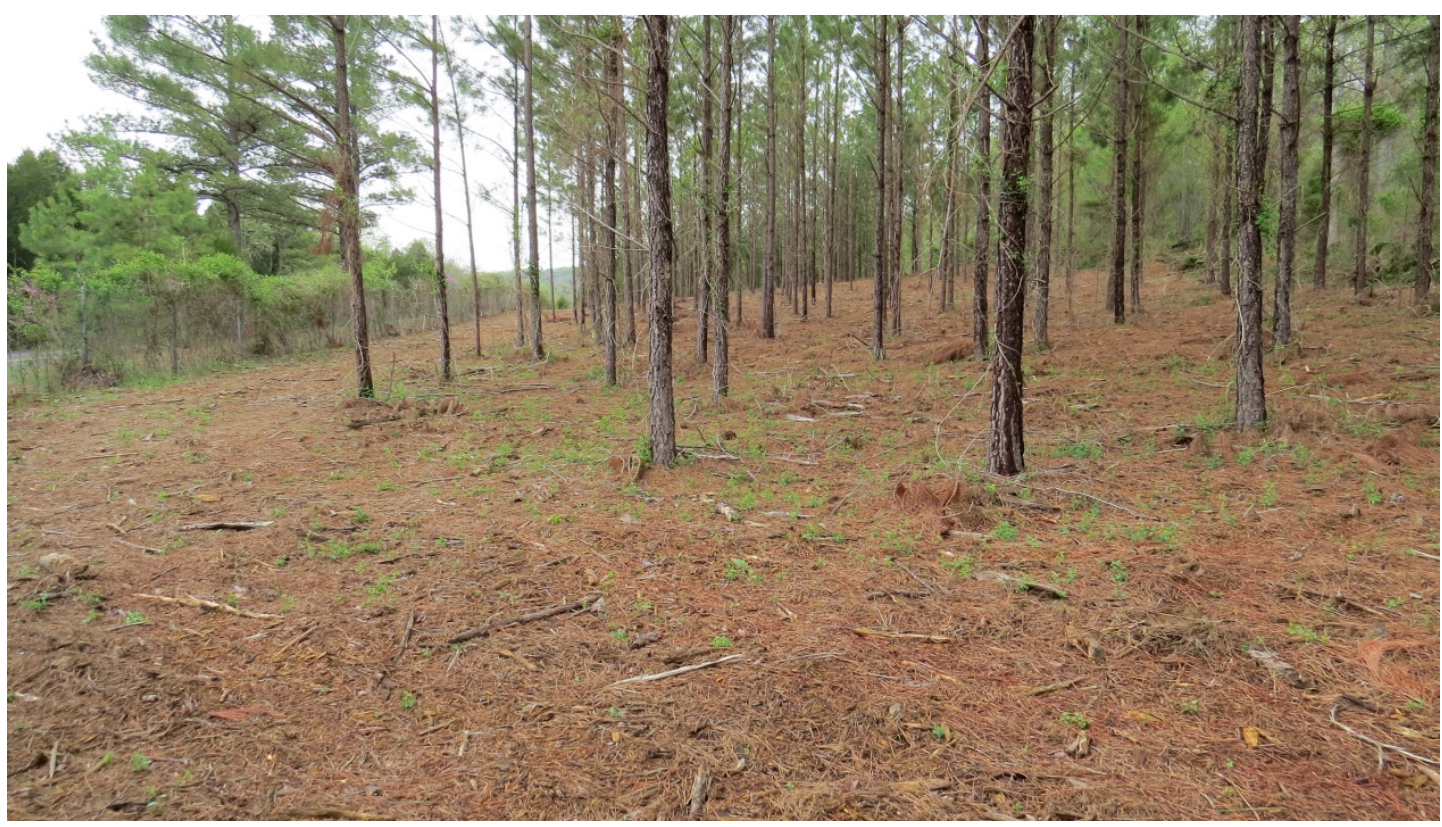

Loblolly Pine Stand, after thinning (April 2014). (Photo: Kelly Roy) 


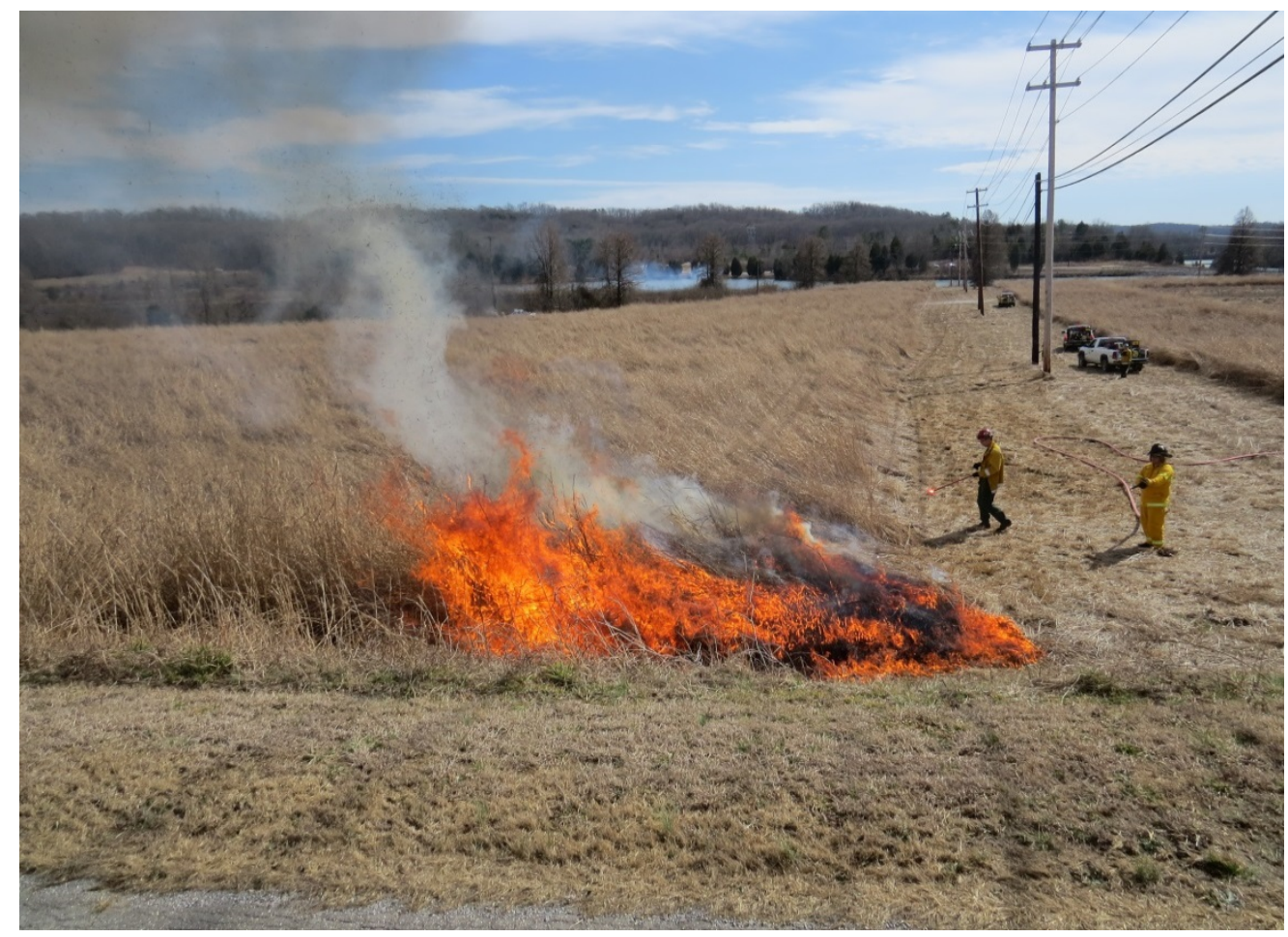

Prescribed burning of switchgrass field at ETTP (February 2014). (Photo: Kelly Roy)

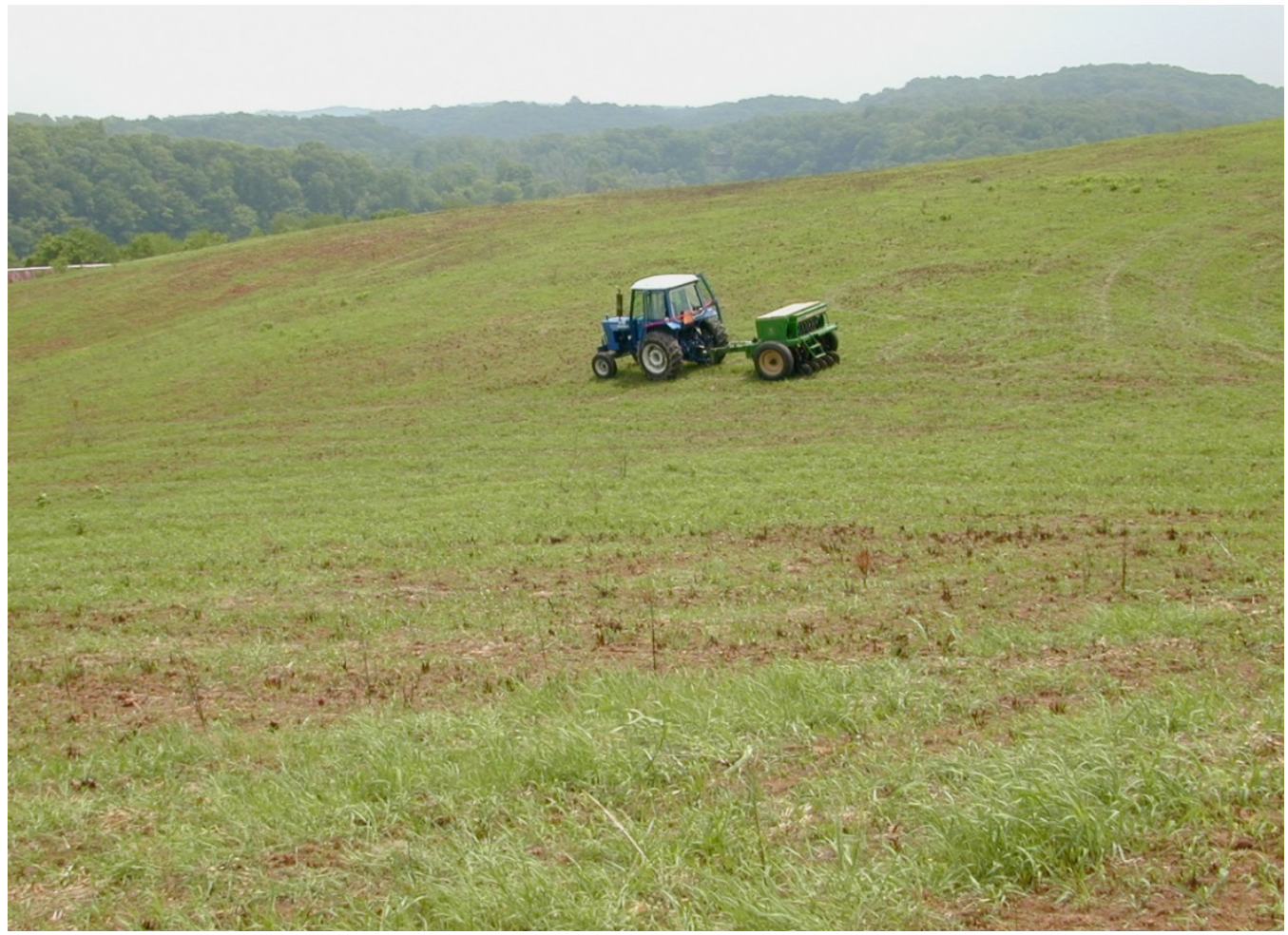

Jim Evans (TWRA) planting native warm season grasses at Freels Bend in 2002 using a no-till drill. (Photo: Michael Ryon) 


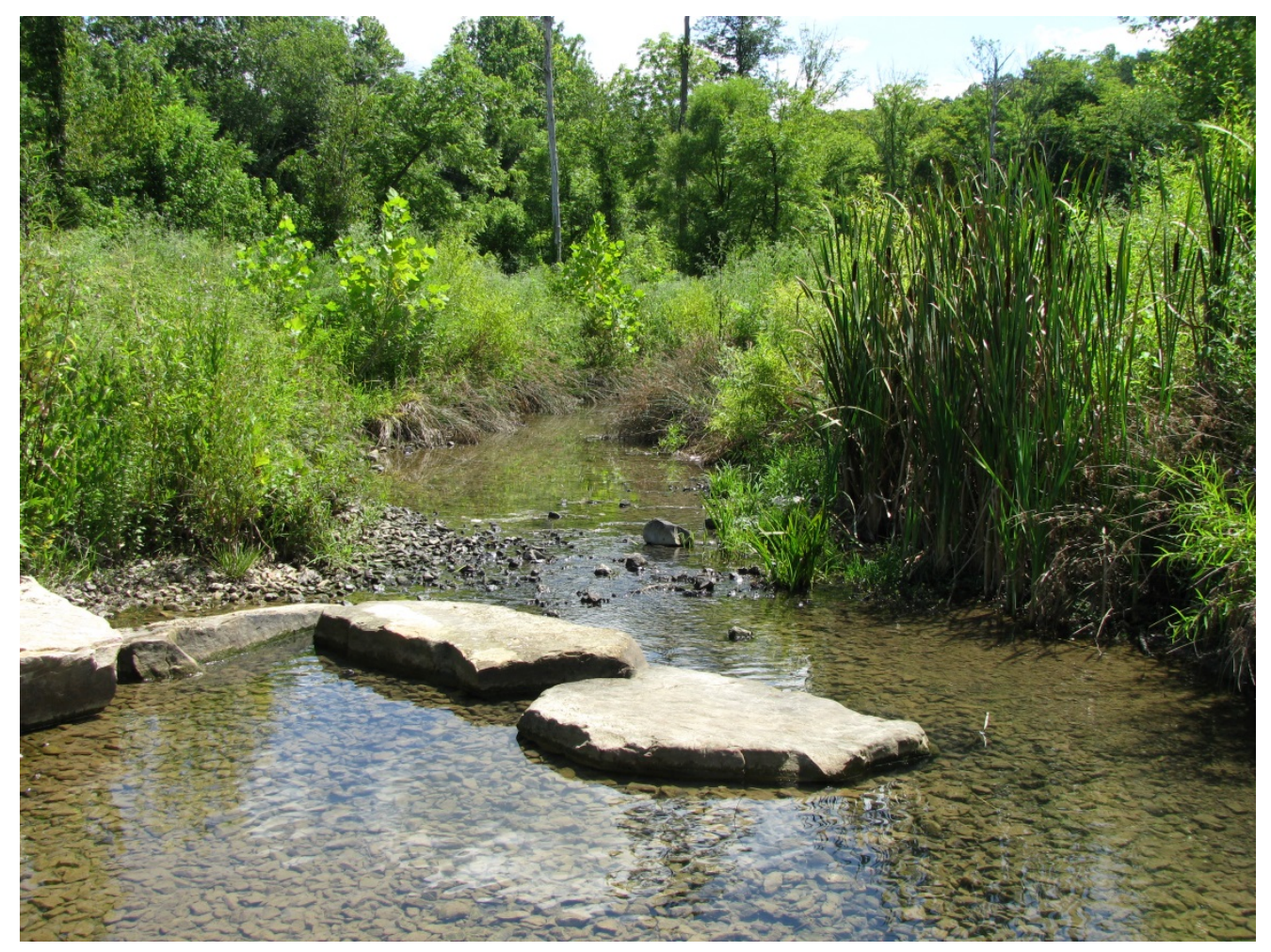

Bear Creek at mile 2.9 (kilometer 4.6), showing rushes, willows, cattails, early succession sycamore, and dead snags (August 2008). (Photo: Kelly Roy)

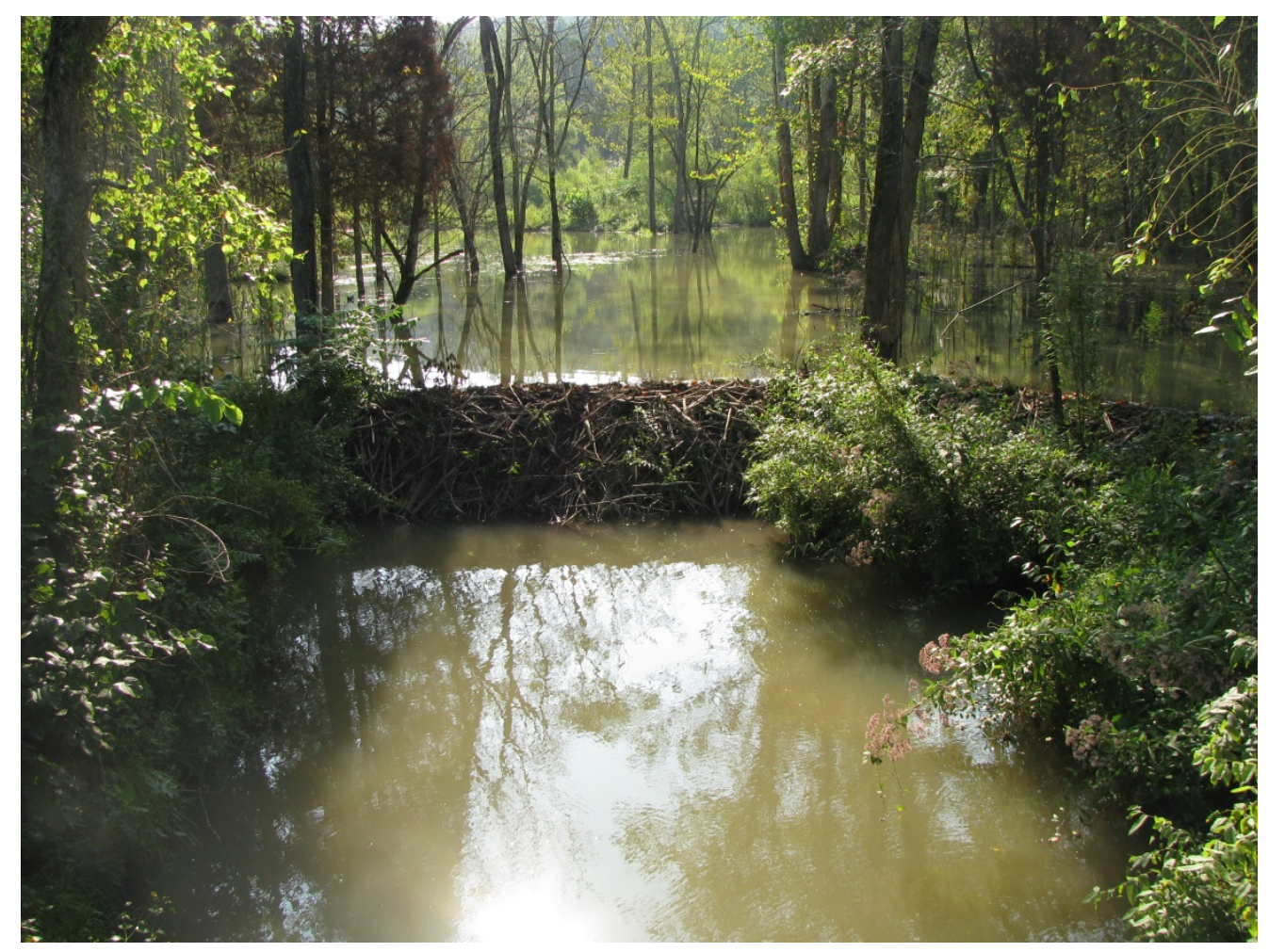

Beaver dam on Bear Creek just upstream of Hwy 95 (August 2010). (Photo: Kelly Roy) 


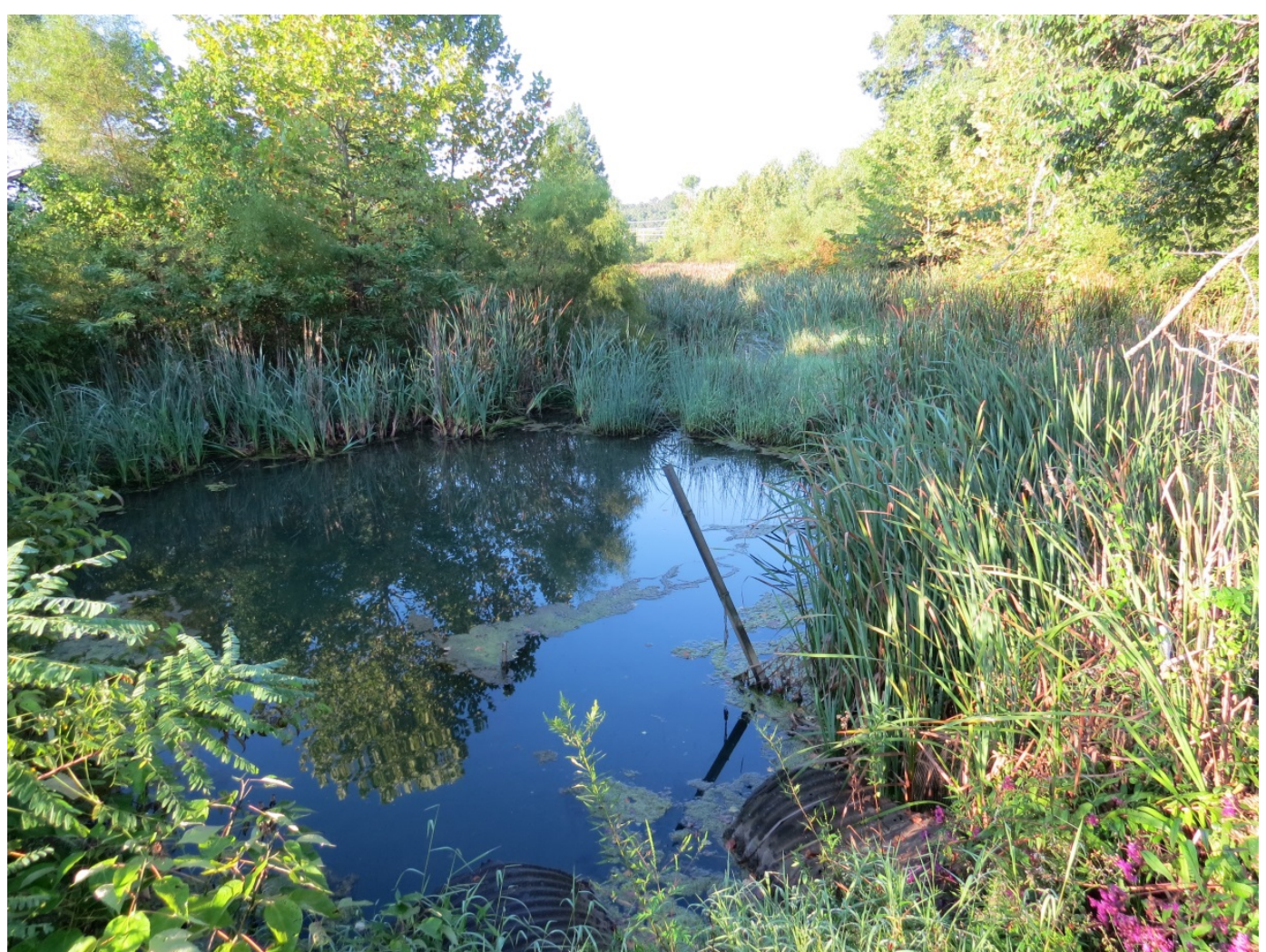

Storm Drain 490, which empties into K-1007-P1 Pond, featuring sora and Virginia rail habitat (September 2013). (Photo: Kelly Roy)

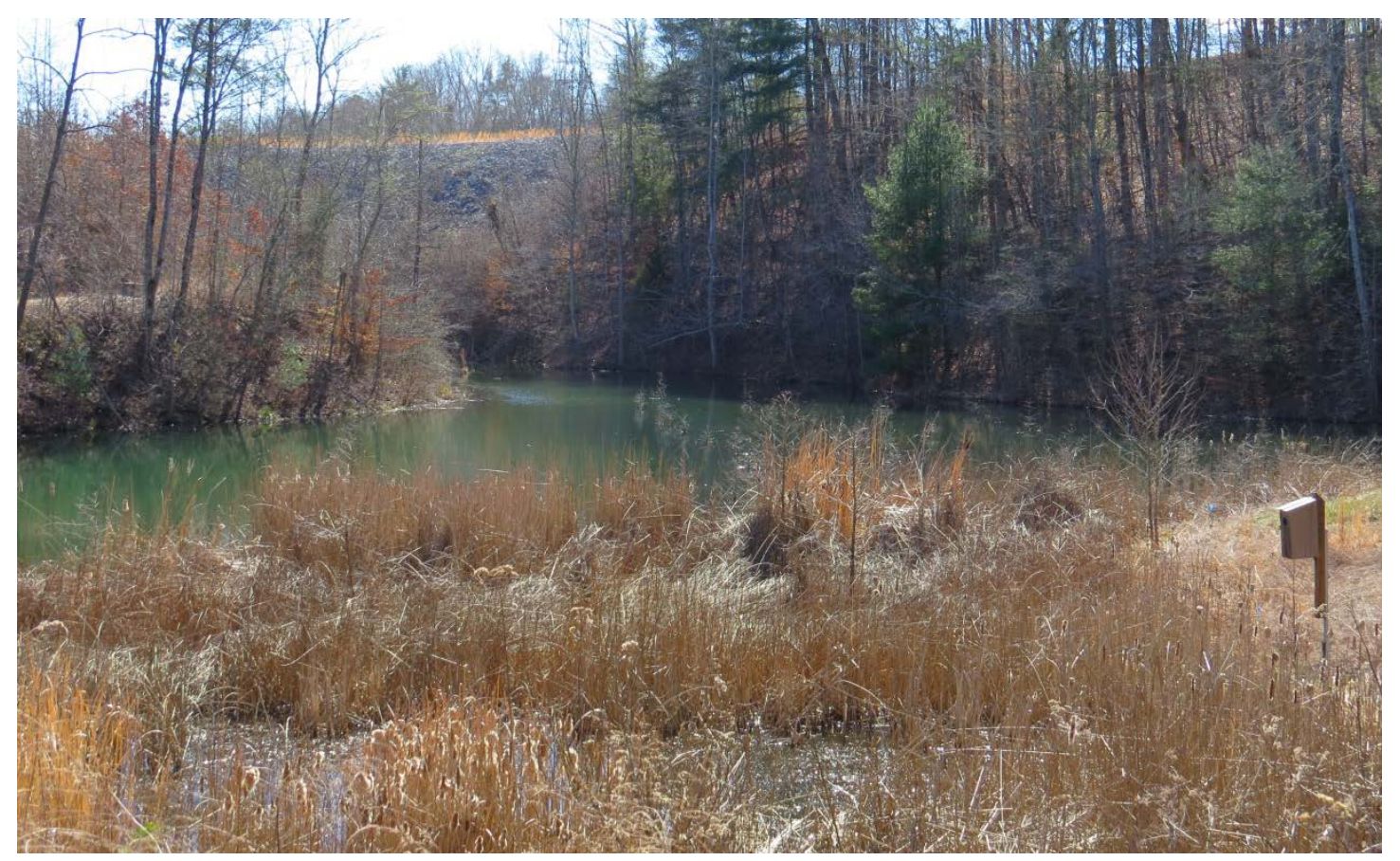

Retention basin at ORNL with wood duck box (March 2010). (Photo: Kelly Roy) 


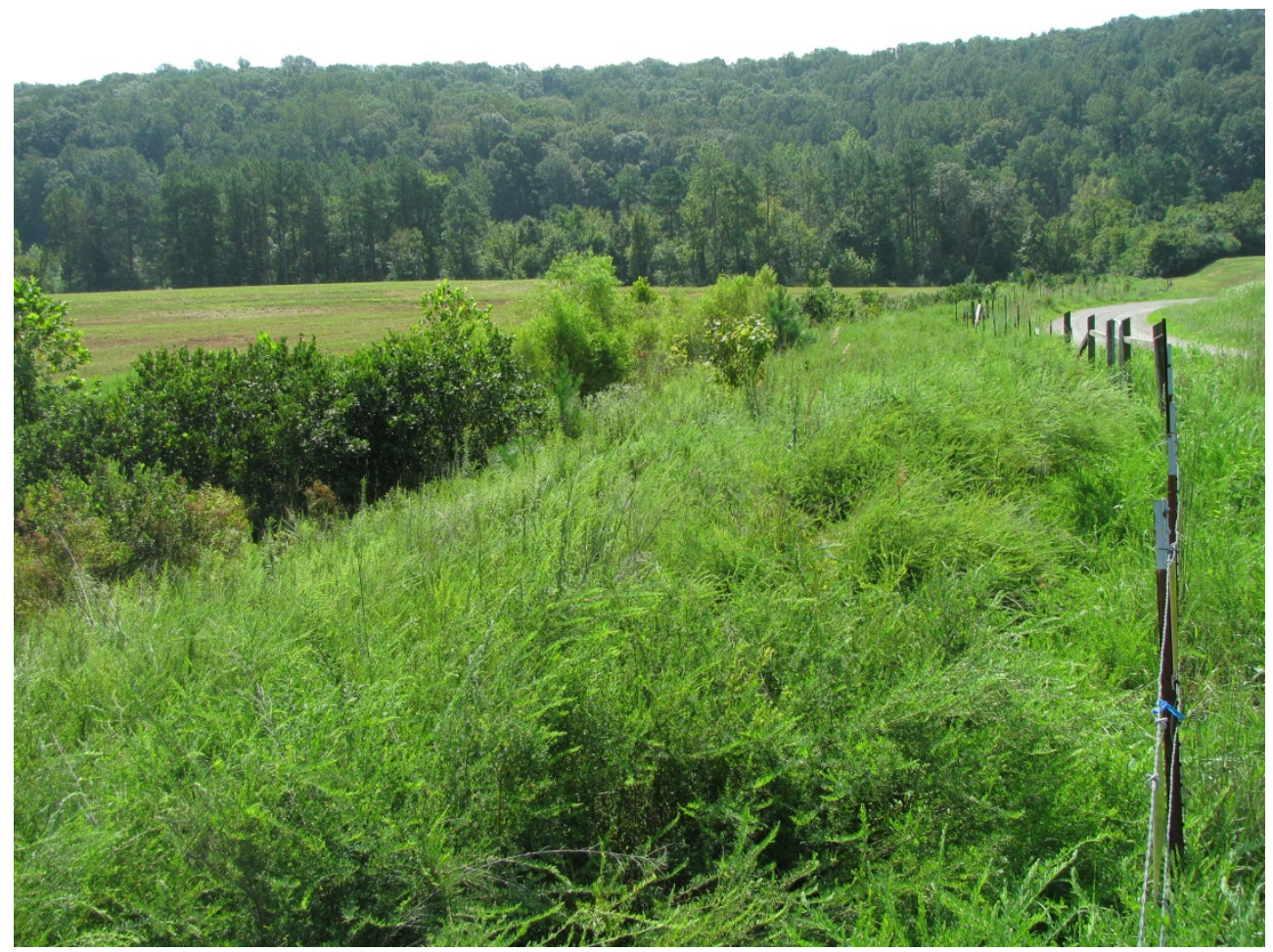

Edge habitat showing interior forest ridge adjacent to mowed field, first order perennial stream, and early succession growth (August 2010). (Photo: Kelly Roy)

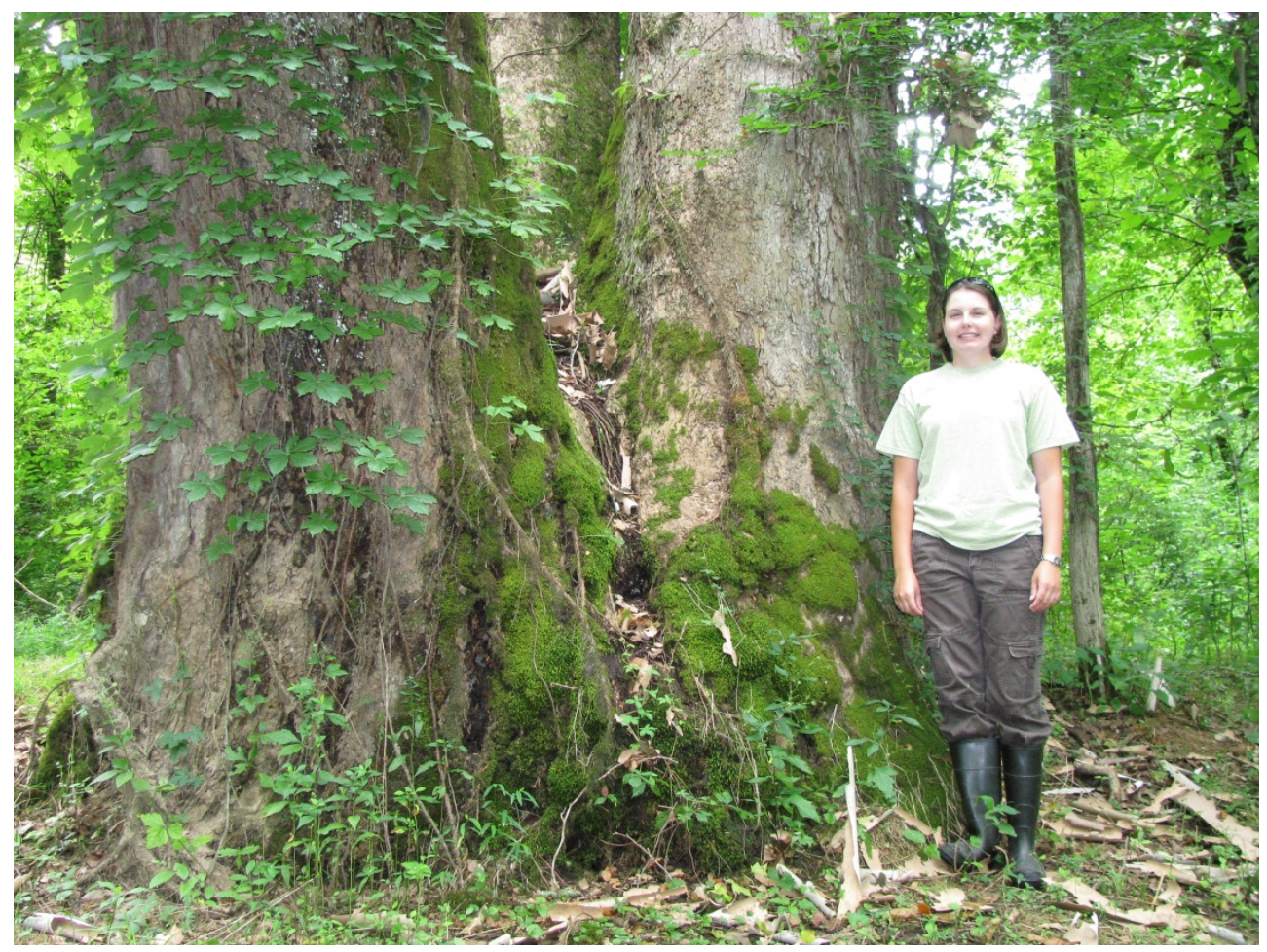

Allison Fortner standing next to an old growth sycamore on the ORR; tree is >150 $\mathrm{ft}$ tall and $>\mathbf{8} \mathrm{ft}$ in diameter (July 2008). (Photo: Kelly Roy) 


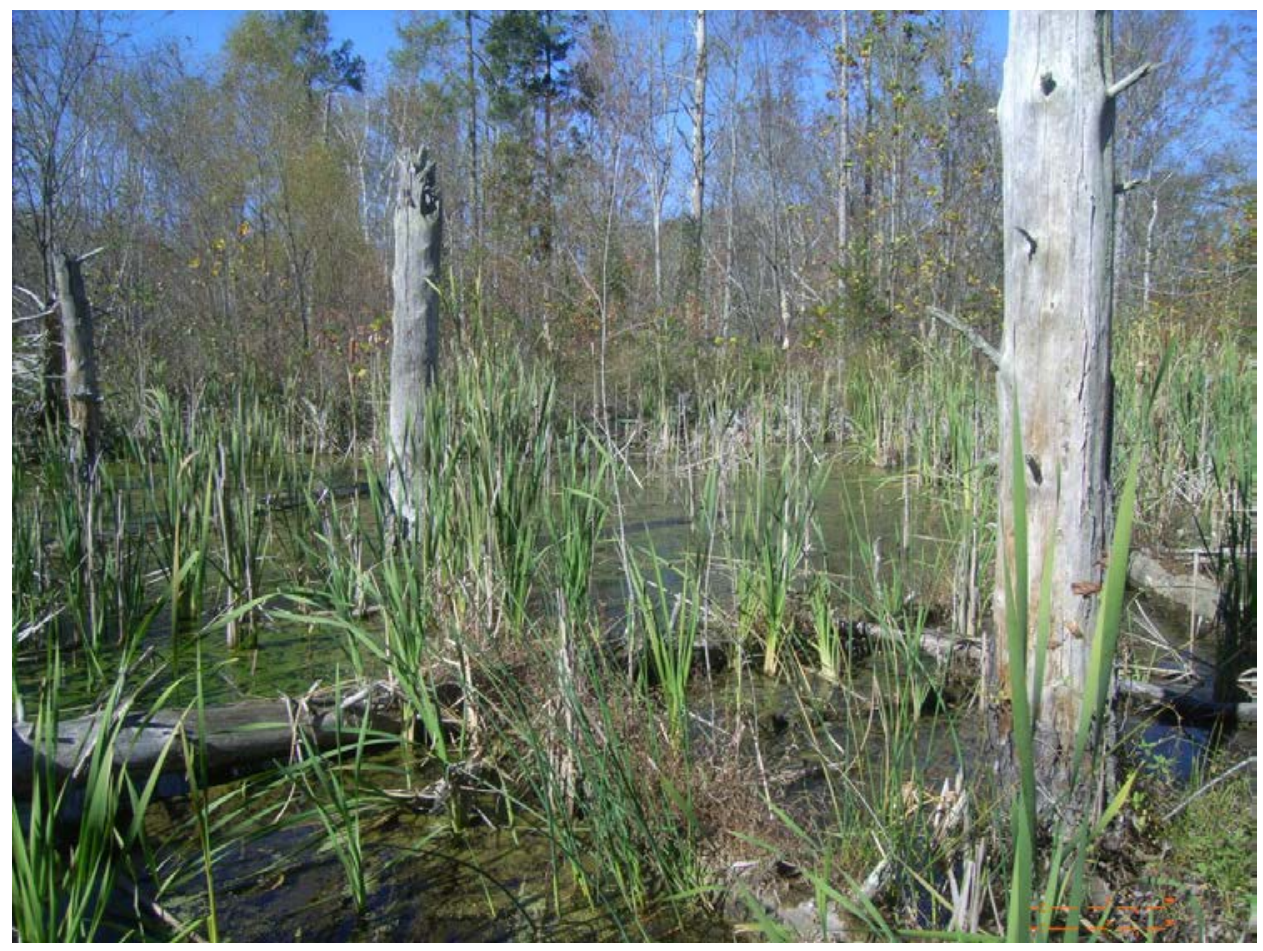

Wetland with snags (October 2010). (Photo: Neil Giffen) 
APPENDIX F. BIRDS ON THE OAK RIDGE RESERVATION 



\section{APPENDIX F. BIRDS ON THE OAK RIDGE RESERVATION}

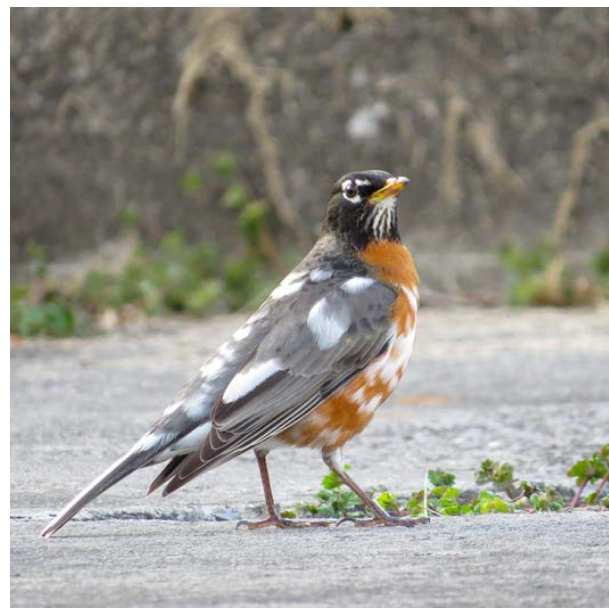

American robin with leucistic pigmentation (Photo: Kelly Roy)

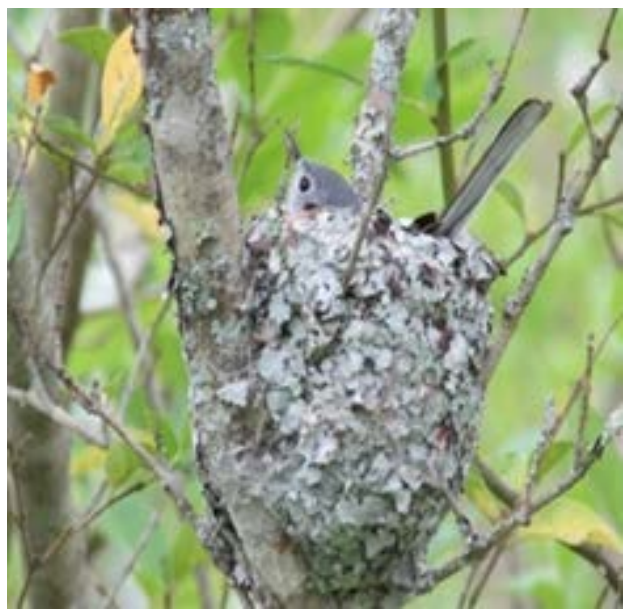

Blue-gray gnatcatcher (Photo: Murray Wade)

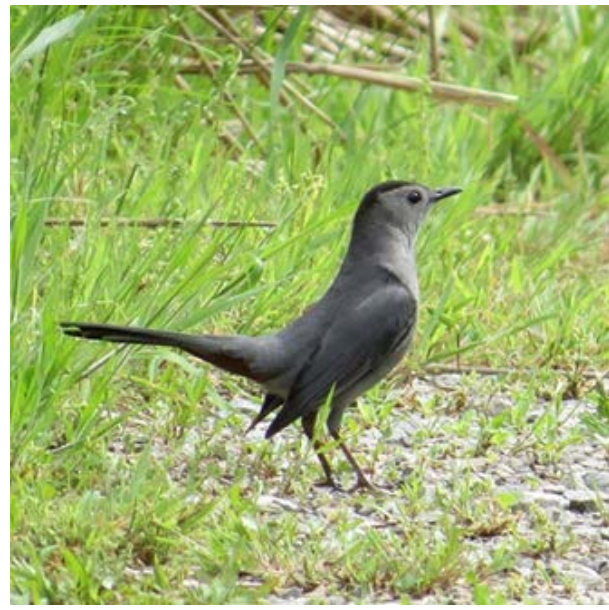

Gray catbird (Photo: Angelina Haines)

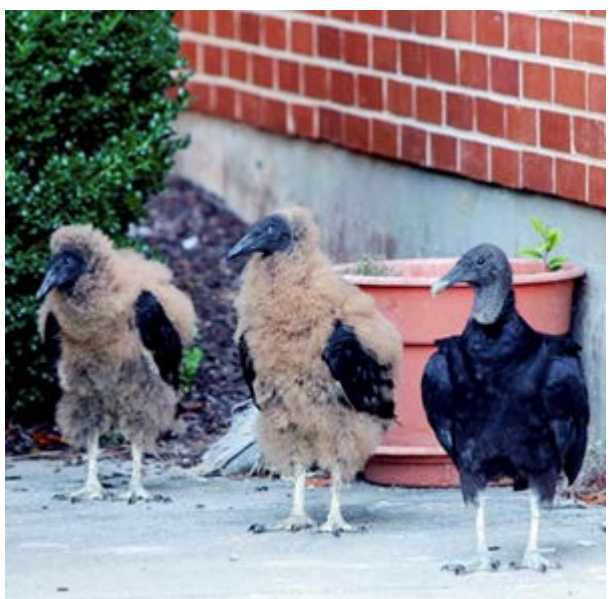

Black vultures (Photo: Jason Richards)

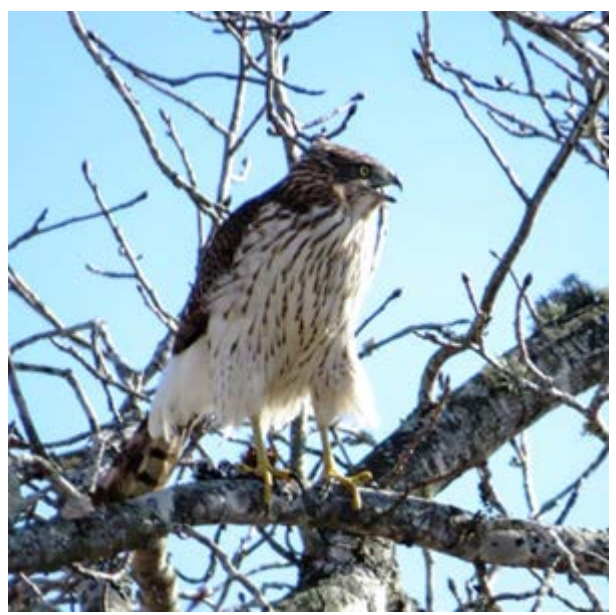

Cooper's hawk (Photo: Angelina Haines)

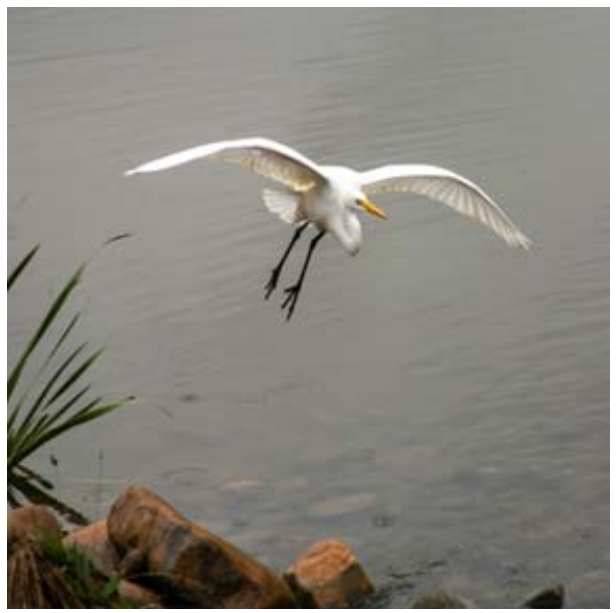

Great egret (Photo: Manuel [Dobie] Gillispie) 


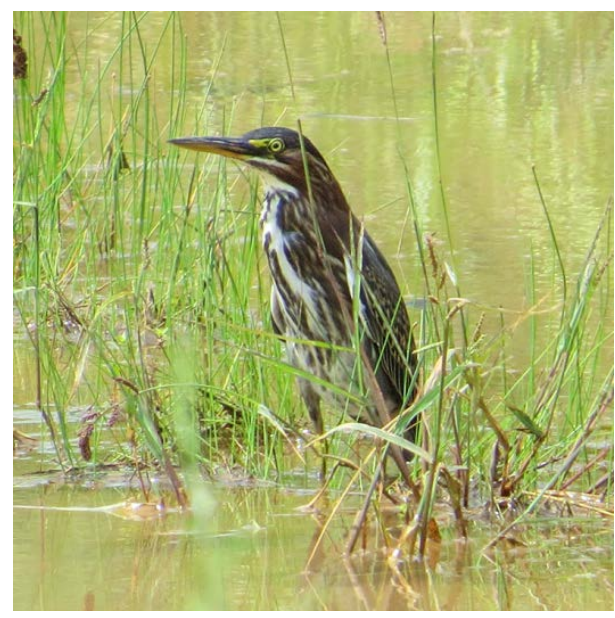

Green heron (Photo: Kelly Roy)

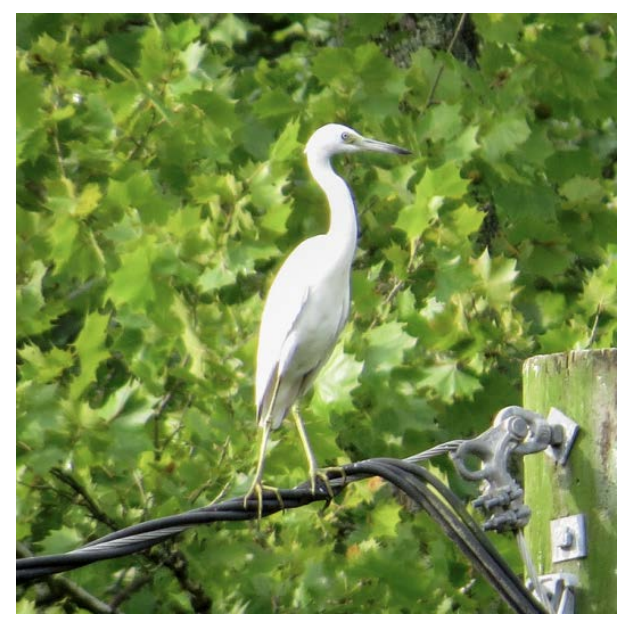

Little blue heron (Photo: Kelly Roy)

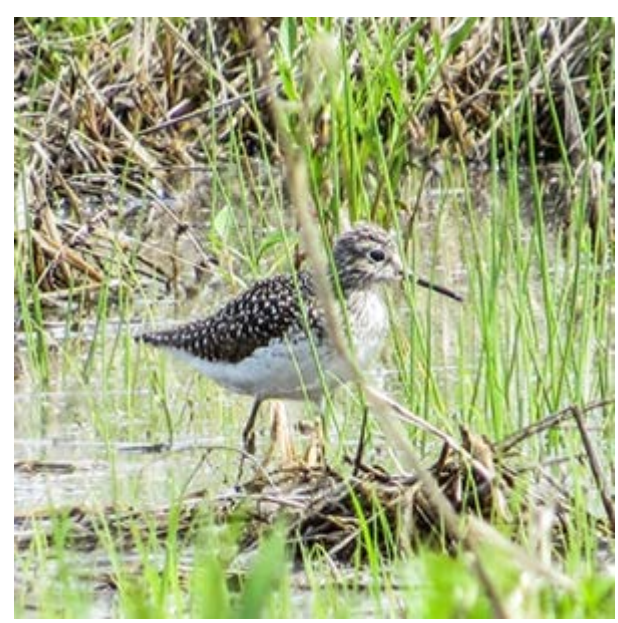

Solitary sandpiper (Photo: Angelina Haines)

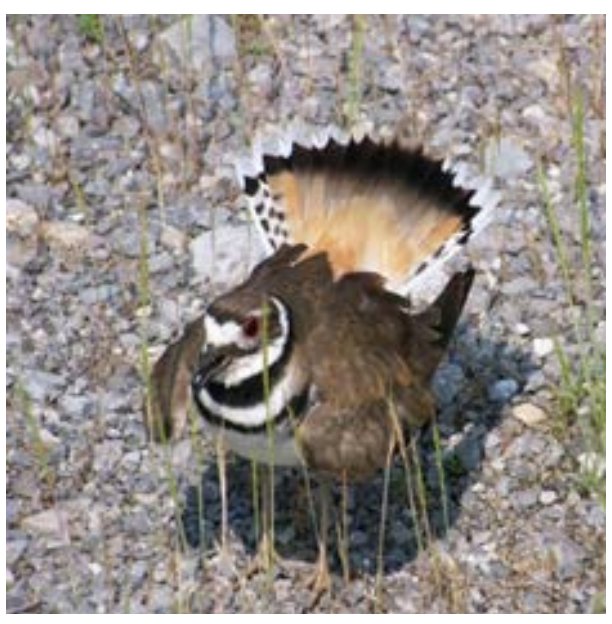

Killdeer (Photo: Doug Colclasure)

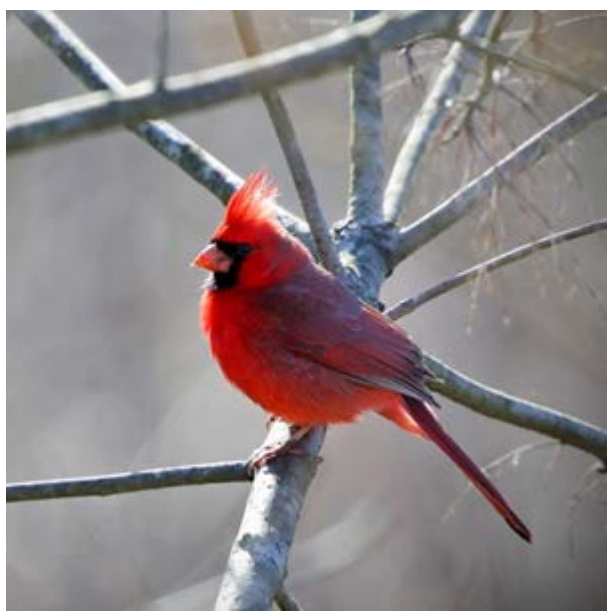

Northern cardinal (Photo: Jason Richards)

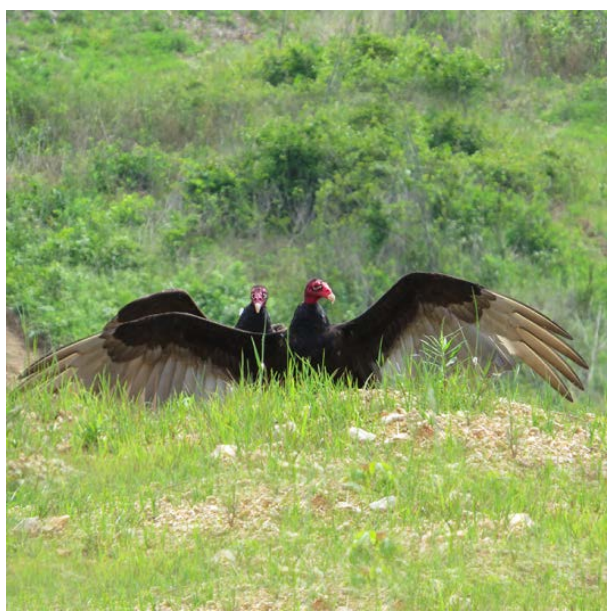

Turkey vultures (Photo: Angelina Haines) 